
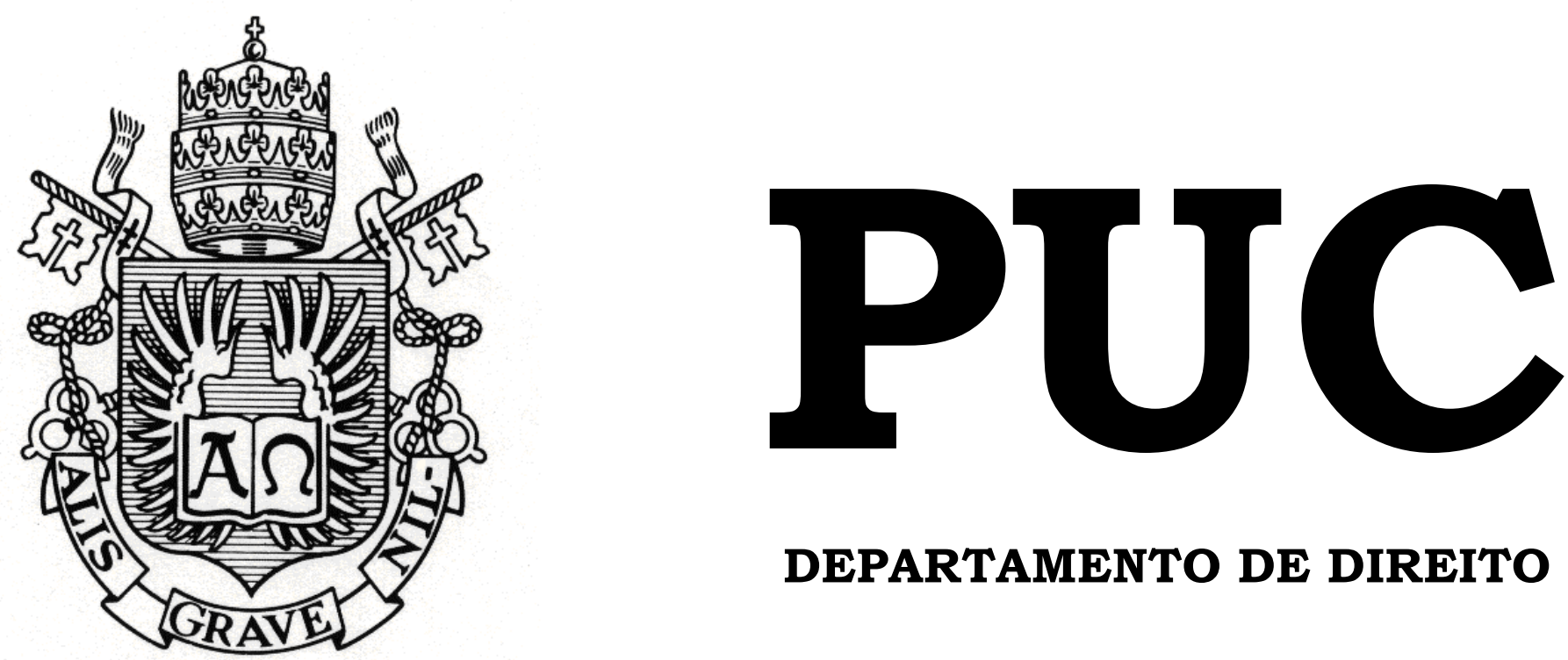

DEPARTAMENTO DE DIREITO

\title{
A PROTEÇÃO CONFERIDA AOS ACIONISTAS MINORITÁRIOS PELO ARTIGO 254-A DA LEI DAS S.A.: UMA ANÁLISE CRÍTICA DO TAG ALONG OBRIGATÓRIO
}

por

PAULA KAPLAN DE FREITAS

ORIENTADOR(A): FRANCISCO ANTUNES MACIEL MÜSSNICH

2019.1

PONTIFÍCIA UNIVERSIDADE CATÓLICA DO RIO DE JANEIRO

RUA MARQUÊS DE SÃO VICENTE, 225 - CEP 22453-900

RIO DE JANEIRO - BRASIL 


\title{
A PROTEÇÃO CONFERIDA AOS ACIONISTAS MINORITÁRIOS PELO ARTIGO 254-A DA LEI DAS S.A.: UMA ANÁLISE CRÍTICA DO TAG ALONG OBRIGATÓRIO
}

\author{
por \\ PAULA KAPLAN DE FREITAS
}

Monografia apresentada ao

Departamento de Direito da Pontifícia Universidade Católica do Rio de Janeiro (PUC-Rio) como requisito parcial para obtenção do título de Bacharel em Direito

Orientador(a): Francisco Antunes Maciel Müssnich 
À minha tia, Cristina. 


\section{Agradecimentos}

Aos meus pais, Sergio e Marion, por fornecerem, cada um do seu jeito, todos os instrumentos que me vêm permitindo alcançar meus objetivos. Nenhuma conquista será inteiramente minha, mas nossa. Também agradeço - e aqui incluo minha irmã, Flávia, e meus irmãos, Julio e Bruno - pela paciência, apoio e carinho. Obrigada por serem a minha base.

Ao meu avô, Janio, por ser esse exemplo de pessoa, me permitindo ser a neta mais orgulhosa do mundo, e à minha avó, Ivone, pelo amor incondicional; à minha tia, Naruna, e à minha avó "mamie", Leslie, por estarem sempre presentes de alguma forma, ainda que da França, nas minhas conquistas.

Aos meus amigos do Lycée Molière, da PUC-Rio e da vida - Helena Lago, Stéphanie Tournaille, Sarah Nadaud, Isabelle Favre, Julia Rocha, Jacqueline Cavalcanti, Gabriela Salah, Gabriela Pelluso, Beatriz Jobim, Talitha Franco, Carolina Arca, Igor Traven, Fernanda Rojtenberg, Thamiris Silvino, Victoria Ramos, Pedro Fernandes, João Nobre, Vitor Afonso, Victor Colacino e Victor Coelho, entre tantos outros - que me ajudaram (e ainda me ajudam, diariamente) a crescer e a me tornar a pessoa que sou hoje, com sua presença tanto nas horas de descontração quanto nos momentos mais sensíveis, e pela compreensão com meus sumiços nessa reta final da faculdade. Agradeço, mais ainda, à Natasha Rojtenberg e à Laura Bardot, pelos conselhos e incentivos diários; à Luiza Szmajzner, pelas dicas oferecidas e pela torcida; ao Miguel Fernandes, por partilhar os mesmos anseios e ambições; ao Luca Manhães, pela rotina puquiana; à Nicole Rozental, pela troca de ideias; à Maitê Rezende, Gabriela Camargo, Thalita Chalhub, Camila Camara, Nicole Favaretto e Mell Bezenover, por acreditarem mais em mim do que eu mesma. Ao Luiz Felipe, pelas inúmeras ajudas, pelo enorme carinho e presença em toda essa trajetória.

Aos colegas dos escritórios Galdino Coelho Mendes, Gustavo Tepedino e Barbosa, Müssnich e Aragão, por tanto contribuírem na minha formação 
pessoal e profissional. Sou especialmente grata ao Rodrigo Requena e à Rafaella Tribuno, antigo chefe e antiga dupla no GTA, que se tornaram verdadeiros amigos; e à minha equipe no BMA: Cinthia Achão, Raissa Xavier, Anna Paula Mesquita, Antonia Castier, Natalie Nevière, por todos os ensinamentos, orientações e apoio, e, claro, ao Felipe Obeid, pela parceria inexplicável. À Ana Luisa Dantas, Letícia Felix, Sarah Castro e a todos os demais companheiros de baia e presentes no meu dia-a-dia, que tornaram o meu cotidiano muito mais leve e prazeroso.

Ao Chico, meu professor, chefe e orientador da monografia. Os meus mais sinceros agradecimentos pela atenção e disposição constantes e, sobretudo, por ser a maior inspiração que eu poderia (e todos deveriam) ter. É uma honra poder contar com você. 


\section{Resumo}

O presente trabalho visa questionar a obrigatoriedade de realização de oferta pública de aquisição de ações aos acionistas minoritários nos casos de alienação do poder de controle de companhia aberta, prevista no artigo 254-A da Lei das Sociedades por Ações, e considerada como mecanismo de boa prática de governança corporativa no mercado de capitais brasileiro. Para tanto, será analisado o conceito de controle na companhia e suas implicações, bem como a figura do acionista controlador no ordenamento jurídico brasileiro. Em seguida, a figura do acionista minoritário e os direitos e mecanismos de proteção de interesses que the são conferidos serão objeto de exame. Por fim, será aprofundado o estudo sobre específica proteção conferida aos minoritários, qual seja, o direito de venda de suas ações em conjunto com as do acionista controlador (o denominado tag along), com a análise das origens, fundamentos, aplicação e (in)eficiência do instituto no ordenamento jurídico e mercado de capitais brasileiros.

Palavras-chave: Poder de Controle. Acionista Controlador. Acionista minoritário. Alienação de controle. Tag Along. Oferta Pública de Ações. 


\section{Sumário}

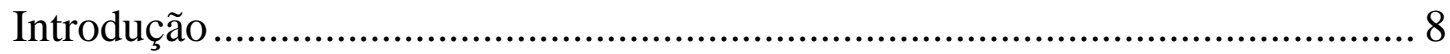

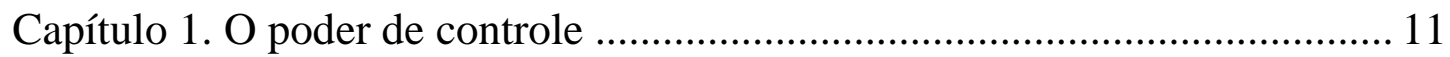

1.1. O conceito de poder de controle ................................................................. 11

1.2. A figura do acionista controlador no ordenamento jurídico brasileiro ..... 15

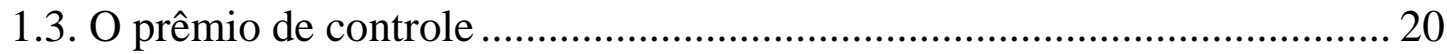

1.3.1. A quem pertence o prêmio de controle? ................................................ 21

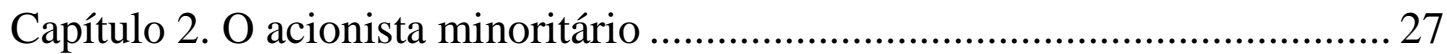

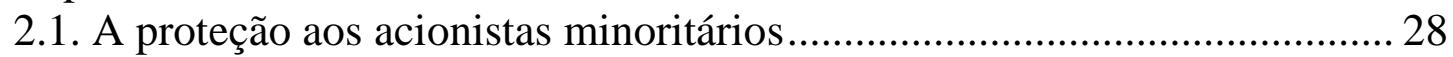

2.1.1. Direitos conferidos pela Lei das S.A................................................... 29

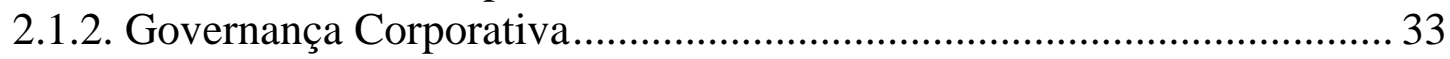

Capítulo 3. A obrigatoriedade de OPA por alienação de controle ..................... 35

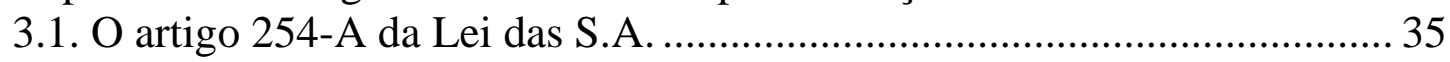

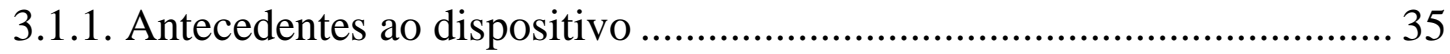

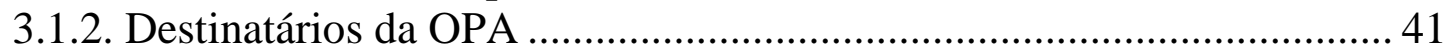

3.1.3. Hipóteses de incidência do artigo 254-A …………................................. 44

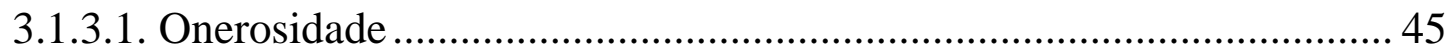

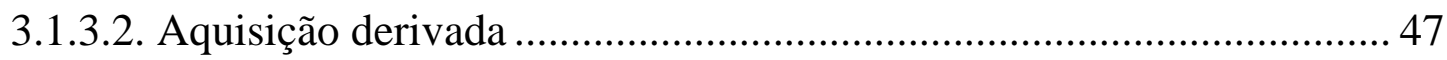

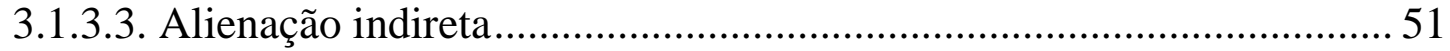

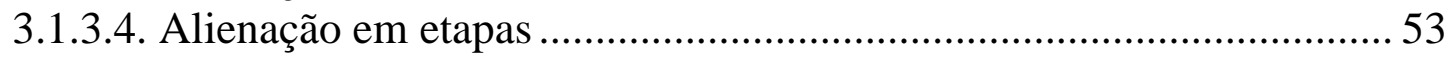

3.1.3.5 Controle não efetivo e controle potencial............................................. 55

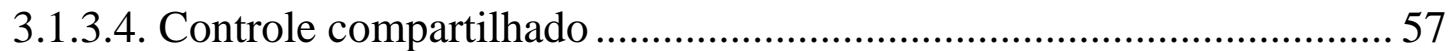

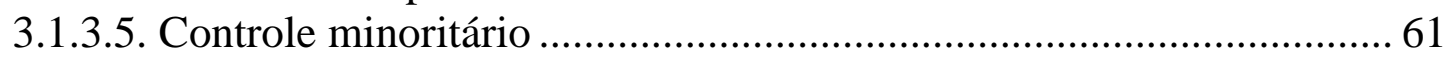

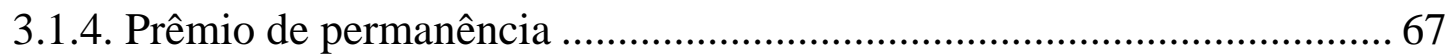

3.2. Boa prática de Governança Corporativa ...................................................... 69

3.3. Finalidades do Tag Along obrigatório e sua (in)eficiência.......................... 70

3.3.1. Tratamento equitativo e prêmio de controle............................................ 71

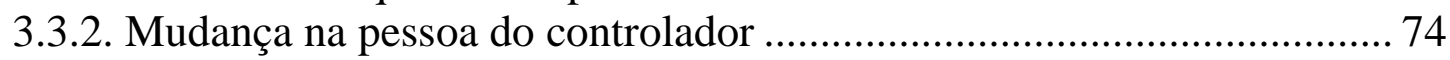

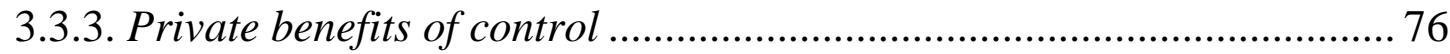

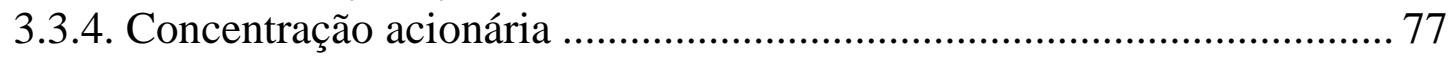

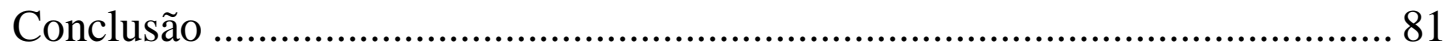

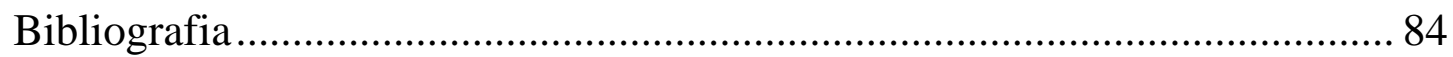




\section{Lista de abreviações}

CVM - Comissão de Valores Mobiliários

Lei das S.A. - Lei $n^{\circ}$ 6.404/76

OPA - Oferta Pública de Ações

IBGC - Instituto Brasileiro de Governança Corporativa 


\section{Introdução}

A Lei $n^{\circ}$ 6.404/76 ${ }^{1}$, mais conhecida como "Lei das S.A.”, prevê uma série de mecanismos de proteção aos acionistas não controladores, permitindo-lhes resguardar seus interesses frente ao controlador. Quanto maior o grau de segurança e confiança daqueles que pretendem investir em uma companhia aberta, menor o custo para captação de recursos, o que incentiva novas emissões de valores mobiliários pela companhia, propiciando um maior desenvolvimento do mercado de capitais e, por consequência, da economia.

A Oferta Pública de Aquisição de Ações - comumente chamada de OPA - é uma operação na qual uma pessoa, física ou jurídica, manifesta seu interesse em adquirir uma certa quantidade de ações de uma companhia, por um prazo e a um preço determinados, e segundo cláusulas e condições previamente estabelecidas - algumas delas possuindo previsões legais expressas, tais como aquelas dos artigos $4^{\circ}, 254-A, 256$ e 257 da Lei das S.A. e na Instrução CVM n ${ }^{\circ}$ $361 / 02^{2}$. A sua realização pode ser voluntária, ou seja, a oferta pública é realizada unicamente por vontade do ofertante, mas também pode ser obrigatória, em casos em que a Lei das S.A. impõe a realização de OPA como condição para uma determinada operação.

$\mathrm{O}$ atual artigo 254-A da Lei ${ }^{\circ}$ 6.404/76, introduzido por ocasião da Lei $\mathrm{n}^{\circ} 10.303 / 2001$, dispõe acerca da obrigatoriedade de se fazer oferta pública de aquisição de ações no caso de alienação de controle de companhia aberta. Determina que o interessado em adquirir as ações do acionista controlador

\footnotetext{
${ }^{1}$ BRASIL. Lei $n^{o}$ 6.404, de 15 de dezembro de 1976. Dispõe sobre as Sociedades por Ações. Disponível em <http://www.planalto.gov.br/ccivil_03/leis/16404consol.htm〉. Acesso em 17 mai. 2019.

${ }^{2}$ CVM, Instrução $n^{o} 361$, de 5 de março de 2002. Dispõe sobre o procedimento aplicável às ofertas públicas de aquisição de ações de companhia aberta, o registro das ofertas públicas de aquisição de ações para cancelamento de registro de companhia aberta, por aumento de participação de acionista controlador, por alienação de controle de companhia aberta, para aquisição de controle de companhia aberta quando envolver permuta por valores mobiliários, e de permuta por valores mobiliários, revoga a Instrução CVM no 229, de 16 de janeiro de 1995, a Instrução CVM nº 299, de 9 de fevereiro de 1999 e a Instrução CVM no 345, de 4 de setembro de 2000, e dá outras providências. Disponível em <http://www.cvm.gov.br/legislacao/instrucoes/inst361.html>. Acesso em 17 mai. 2019.
} 
deverá se propor a adquirir, na mesma oportunidade, as ações com direito de voto dos demais acionistas com direito de voto da companhia - conferindo-lhes a possibilidade de sair da companhia junto com o acionista controlador - pelo equivalente de no mínimo $80 \%$ do preço pago pelas ações integrantes do bloco de controle.

Esse direito ao tag along também tem sido incentivado no mercado de capitais brasileiro como prática de Governança Corporativa, sendo imposto com regras ainda mais rígidas em determinados segmentos de listagem da Bolsa de Valores Brasileira (atual B3).

Embora seja uma vantagem e proteção a mais ao acionista minoritário, o que poderia lhe dar mais segurança para decidir investir no mercado de valores mobiliários, tal mecanismo parece constituir um ônus bastante significativo para o adquirente do controle de uma companhia - podendo até mesmo inviabilizar o negócio. Até que ponto, portanto, ele se justifica?

Ressalta-se ainda que o preço estabelecido na alienação do controle, ou seja, no negócio jurídico de compra e venda do conjunto de ações do acionista controlador de uma companhia, é geralmente superior ao valor de mercado que resultaria da soma dessas ações se individualmente consideradas. Esse valor adicional, usualmente denominado de ágio ou prêmio de controle, se justifica na medida em que a aquisição conjunta dessas ações garante o exercício do poder de controle. Baseando-se na noção de tratamento igualitário, entre outros fundamentos, há quem entenda, contudo, que os titulares das demais ações (não pertencentes ao bloco de controle) da companhia também fazem jus ao pagamento do prêmio de controle.

Ora, a Lei das S.A. busca, explicitamente, identificar e definir a figura do acionista controlador a fim de lhe imputar um conteúdo maior de deveres e responsabilidades - conforme se denota, principalmente, de seus artigos $116 \mathrm{e}$ 117. A apropriação do prêmio de controle pelo acionista controlador não se 
justificaria, portanto, pelo seu dever de conduzir o empreendimento e pelas responsabilidades diferenciadas que possui em relação aos demais acionistas?

Para responder tais indagações, o primeiro capítulo abrangerá um panorama geral sobre o poder de controle e a figura do acionista controlador no ordenamento jurídico brasileiro. Já no segundo capítulo, será analisada a figura do acionista minoritário, bem como as proteções e mecanismos limitadores do poder de controle a ele conferidos. Por fim, o terceiro capítulo se dedicará ao estudo da alienação do poder de controle de companhia aberta, operação condicionada à realização de OPA aos demais acionistas com direito de voto (que não os controladores) com o fim de proteger o interesse destes em detrimento do direito do acionista controlador dispor livremente de suas ações. 


\section{Capítulo 1. 0 poder de controle}

\subsection{O conceito de poder de controle}

A compreensão do poder de controle em uma companhia é fundamental para a definição de acionista controlador, destinatário de uma série de deveres e responsabilidades próprias a ele, bem como para a identificação de uma operação de alienação do controle que, por consequência atrai a incidência do artigo 254-A da Lei das S.A.

São inúmeros os estudos e as classificações existentes no âmbito do direito societário que giram em torno do conceito de controle nas companhias e, mais especificamente, nas companhias abertas.

Em um sentido mais generalizado, o poder de controle poderia ser qualificado como "o poder de decidir, em última instância, a atividade empresarial". ${ }^{3}$

Deter o controle de uma companhia significa comanda-la, ou seja, direcionar suas atividades da forma que julgar mais conveniente, nomear os administradores e fixar sua remuneração, estabelecer o ritmo de crescimento da empresa, definir quando devem ser emitidos novos valores mobiliários - tudo, evidentemente, dentro dos limites previstos na Lei e no Estatuto Social. ${ }^{4}$

No âmbito internacional, uma das obras que exerceu mais influência sobre o tema é aquela elaborada pelos professores Adolf Berle e Gardiner Means ${ }^{5}$, que, em resumo, demonstraram que a direção de uma companhia é exercida por um conselho de administração, estando o controle da sociedade nas

\footnotetext{
${ }^{3}$ CVM, Processo no 2006/6209, Reg. no 5256/2006, Rel. Diretor Wladimir Castelo Branco Castro, Rio de Janeiro, 25 set. 2006. Disponível em <http://www.cvm.gov.br/decisoes/2006/20060925_R1.html>. Acesso em 17 mai. 2019.

${ }^{4}$ PENNA, Paulo Eduardo. Alienação de controle de companhia aberta. In: COELHO, Fábio Ulhoa (Coord.). Tratado de direito comercial: relações societárias e mercado de capitais. São Paulo: Saraiva, 2015. p. 299-300.

${ }^{5}$ BERLE, Adolf A.; MEANS, Gardiner C. A moderna sociedade anônima e a propriedade privada. Tradução de Dinah de Abreu Azevedo. São Paulo: Abril Cultural, 1984. p. 85.
} 
mãos da pessoa ou do grupo de pessoas que tem o poder efetivo de selecionar os membros do conselho de administração (ou a sua maioria).

Os autores identificaram cinco espécies de controle: (i) através da propriedade quase total, (ii) majoritário, (iii) por meio de mecanismos legais, (iv) minoritário e (v) administrativo ou gerencial.

Fábio Konder Comparato ${ }^{6}$ critica a classificação de controle por meio de mecanismos legais ${ }^{7}$, por tratar de hipóteses que se confundem com as outras espécies de controle ou que não se encontram em outros sistemas jurídicos, sendo próprias do ordenamento norte-americano.

Em relação ao controle através da propriedade quase total, este se assimilaria, no entender de Berle e Means, à sociedade unipessoal, onde há um único titular do capital social: não haveria, portanto, a possibilidade de um conflito de interesses entre sócios, mas apenas entre o sócio único e a sociedade, quando sua atuação vir a conflitar com o interesse da sociedade, prejudicando terceiros e possibilitando a desconsideração da personalidade jurídica em favor dos credores da sociedade. ${ }^{8}$

Comparato, no entanto, entende que a sociedade cujo controle se funda na quase completa propriedade acionária pressupõe a pluralidade de acionistas, não havendo que se falar em sócio único. Há sempre uma minoria, ainda que reduzida à mínima expressão (eis que o controlador possuirá a quase total propriedade acionária). Dessa forma, o autor prefere falar em "controle totalitário" nos casos em que nenhum acionista é excluído do poder de

\footnotetext{
${ }^{6}$ COMPARATO, Fábio Konder; SALOMÃO FILHO, Calixto. O Poder de Controle na Sociedade Anônima. $5^{\text {a }}$ ed.. Rio de Janeiro: Forense, 2008. p. 64.

${ }^{7}$ Trata-se da manutenção do controle da empresa não através da propriedade de um grande número de ações com direito a voto, mas mediante determinados mecanismos previstos em lei. Exemplos disso são, dentre outros, (i) o mecanismo piramidal, que envolve a posse da maioria das ações de uma empresa que, por sua vez, detém a maioria das ações de outro, e assim sucessivamente, e (ii) o voto por procuração, que envolve a criação de um grupo de procuradores, muitas vezes membros da administração, com total poder de voto sobre todas as ações a ele confiadas. Nesse sentido, cf. BERLE, Adolf A.; MEANS, Gardiner C. A moderna sociedade anônima e a propriedade privada. Tradução de Dinah de Abreu Azevedo. São Paulo: Abril Cultural, 1984. p. 87-90.

${ }^{8}$ COMPARATO, Fábio Konder; SALOMÃO FILHO, Calixto. Op. cit., p. 52-53.
} 
dominação da sociedade, seja ela unipessoal, seja ela do tipo familiar: a unanimidade é de rigor. ${ }^{9}$

O controle majoritário, por sua vez, fica configurado quando a maioria das ações com direito a voto é detida por um acionista ou grupo de acionistas, e esta maioria vai comandar a companhia. A adoção do princípio majoritário pelas legislações em geral que disciplinam as sociedades por ações se explica pelo fato de que este tipo de sociedade foi concebido justamente para permitir a constituição de um vasto corpo acionário, não sendo razoável exigir o consentimento unânime nas deliberações sociais. ${ }^{10}$

É possível, contudo, que o poder de controle seja exercido por um acionista ou grupo de acionistas titular de menos da metade do capital votante: trata-se do controle minoritário. Tal cenário pode ocorrer nas hipóteses (i) em que, embora exista um acionista majoritário, o mesmo não exerça de fato o poder de controle, deixando de comparecer às assembleias e de participar das decisões da companhia; ou (ii) de dispersão das ações da companhia no mercado, uma vez que nenhum outro acionista ou grupo está organizado ou detém maior número de ações com direito de voto. ${ }^{11}$

O controle administrativo ou gerencial, também chamado de "controle pulverizado" 12 , por fim, seria aquele fundado não na participação acionária, mas nas prerrogativas da administração: são os administradores que exercem o controle da companhia. Essa modalidade se encontra em companhias com o capital extremamente disperso, de modo que nenhum acionista detém condições de tomar o controle e impor sua vontade nas deliberações sociais. Tal cenário pode se dar, inclusive, de maneira proposital, através de restrições estabelecidas pelo Estatuto Social:

\footnotetext{
${ }^{9}$ COMPARATO, Fábio; SALOMÃO FILHO, Calixto. O Poder de Controle na Sociedade Anônima. $5^{\mathrm{a}}$ ed.. Rio de Janeiro: Forense, 2008. p. 54-60.

${ }^{10}$ Ibid. p. 60-63.

${ }^{11}$ EIZIRIK, Nelson. Direito Societário: Estudos e Pareceres. São Paulo: Quartier Latin, 2015. p. 414.

${ }^{12}$ Id., Lei das S.A comentada: artigos 80 ao 137. $2^{\mathrm{a}}$ ed.. São Paulo: Quartier Latin, 2015. p. 229-230.
} 
No modelo de 'controle pulverizado', a direção efetiva dos negócios sociais é realizada por administradores profissionais, membros do conselho de administração e da diretoria, no exercício de suas funções legais e estatutárias, sem que exista um bloco de controle que assegure o poder de controle.

Para tanto, a companhia emite apenas ações com direito de voto, podendo ainda restringir, estatutariamente, o número máximo de votos de cada acionista (por exemplo, em 5\% do capital social) independentemente da participação acionária por eles detida, o que é permitido pela Lei das S.A.

[...]

Também são traços característicos do modelo de controle pulverizado: (i) a existência de um conselho de administração cujos membros são efetivamente independentes; e (ii) uma relativa passividade dos acionistas, que quase não participam nas decisões sobre os negócios sociais. ${ }^{13}$

Ressalta-se que as classificações supracitadas estão inseridas dentro da categoria de controle interno, isto é, aquele exercido no interior da companhia, por pessoas, físicas ou jurídicas, vinculadas àquela estrutura. Nas palavras de Comparato, "controle interno haverá toda vez que esse poder estiver em mãos de titulares de direitos próprios de acionista, ou de administradores". ${ }^{14}$

Porém admite-se que o poder de controle não seja manifestado somente dentro da companhia, podendo haver também um controle externo. Neste caso, o controle pertence a uma ou mais pessoas, físicas ou jurídicas, que não compõem quaisquer órgãos da companhia, mas agem de fora, se encontrando em uma posição de poder perante a companhia, exercendo uma "influência dominante"15. Tal pode ocorrer, por exemplo, quando uma companhia se encontra endividada e passa a se submeter à vontade de seu credor (um Banco, por exemplo), que começa a impor certas condições e exigências de modo a determinar a política da companhia. ${ }^{16}$

\footnotetext{
${ }^{13}$ EIZIRIK, Nelson. Lei das S.A comentada: artigos 80 ao 137. 2a ed.. São Paulo: Quartier Latin, 2015. p. 230-231.

${ }^{14}$ COMPARATO, Fábio Konder; SALOMÃO FILHO, Calixto. O Poder de Controle na Sociedade Anônima. 5a Ed.. Rio de Janeiro: Editora Forense, 2008. p. 88.

15 Ibid. Passim.

${ }^{16}$ BERLE, Adolf A.; MEANS, Gardiner C. A moderna sociedade anônima e a propriedade privada. Tradução de Dinah de Abreu Azevedo. São Paulo: Abril Cultural, 1984. p. 85.
} 


\subsection{A figura do acionista controlador no ordenamento jurídico brasileiro}

$\mathrm{Na}$ legislação brasileira, embora o conceito de controle não esteja expressamente indicado, a Lei $n^{\circ}$ 6.404/76 inovou - tendo em vista que não havia no diploma anterior (Decreto Lei ${ }^{\circ}$ 2.627/40) qualquer previsão nesse sentido - ao estabelecer a definição de acionista controlador.

O diploma revogado tinha como critério o voto prevalecente em cada assembleia, sendo os acionistas divididos simplesmente entre ordinários e preferenciais. E mesmo para aqueles ordinários cuja vontade prevalecia - os ditos "acionistas majoritários" (que diferem da atual figura do acionista controlador) - não eram previstas quaisquer responsabilidades específicas. $\mathrm{O}$ comando da companhia era atribuição dos administradores, os quais respondiam pela má gestão. ${ }^{17}$

Atualmente, no entanto, o acionista controlador é reconhecido pela Lei das S.A. como uma figura de extrema relevância na organização da companhia, sendo o seu papel diferente daquele exercido pelos demais acionistas. Tal fato pode ser constatado pelo cuidado da lei ao determinar tanto os elementos necessários para a caracterização da figura do acionista controlador, quanto os seus deveres e responsabilidades próprios. Nos termos do caput do artigo 116 da Lei $n^{\circ}$ 6.404/76:

Art. 116. Entende-se por acionista controlador a pessoa, natural ou jurídica, ou o grupo de pessoas vinculadas por acordo de voto, ou sob controle comum, que:

a) é titular de direitos de sócio que lhe assegurem, de modo permanente, a maioria dos votos nas deliberações da assembléia-geral e o poder de eleger a maioria dos administradores da companhia; e

b) usa efetivamente seu poder para dirigir as atividades sociais e orientar o funcionamento dos órgãos da companhia.

\footnotetext{
${ }^{17}$ CARVALHOSA, Modesto. Comentários à Lei de Sociedades Anônimas: arts. 75 a 137. $5^{\text {a Ed.. São }}$ Paulo: Saraiva, 2011. p. 562-563.
} 
O mesmo conceito foi reproduzido no artigo $243, \S 2^{\circ}$, do referido diploma, que traz a definição de sociedade controladora e sociedade controlada - embora sem necessidade de fazer menção ao uso efetivo do poder, mencionado na alínea b) do artigo 116, uma vez que o poder de controle constitui o próprio objeto da sociedade controladora:

Art. $243, \S 2^{\circ}$ Considera-se controlada a sociedade na qual a controladora, diretamente ou através de outras controladas, é titular de direitos de sócio que lhe assegurem, de modo permanente, preponderância nas deliberações sociais e o poder de eleger a maioria dos administradores.

Extrai-se dos dispositivos o reconhecimento da existência de controle indireto pela Lei das S.A. Diferentemente do controle direto, onde a relação de poder se estabelece na estrutura interna da sociedade, entre o acionista controlador (titular de ações de emissão da companhia que formam o bloco de controle) e os órgãos da sociedade, no controle indireto a relação de poder se dá entre um grupo ou estrutura de sociedades ${ }^{18}$.

Trata-se de uma cadeia hierarquizada composta de duas ou mais sociedades, em que uma controla o capital da outra, e o controlador final não é, ele próprio, acionista da companhia objeto, embora a controle de forma indireta. A fonte do poder decorre das relações societárias entre as sociedades do grupo: o poder de controle não é exercido apenas nas assembleias gerais da companhia objeto, mas nos órgãos da sociedade controladora, onde são tomadas decisões a respeito da sociedade controlada e sobre a escolha de seus administradores. ${ }^{19}$

Assim, por exemplo, se A controla uma holding e esta detém o controle acionário da companhia B, caracteriza-se o controle indireto de A sobre B. Nesse caso, o controle

\footnotetext{
${ }^{18}$ LAMY FILHO, Alfredo; PEDREIRA, José Bulhões (Coord.). Direito das Companhias. Rio de Janeiro: Forense, 2009. p.834.

${ }^{19}$ PENNA, Paulo Eduardo. Alienação de Controle de Companhia Aberta. São Paulo: Quartier Latin, 2012. p. 125.
} 
não é exercido diretamente, uma vez que A não é acionista de $\mathrm{B}$, mas indiretamente, mediante o voto e o poder de mando da holding, controlada por A. ${ }^{20}$

De todo modo, não restam dúvidas em relação aos requisitos cumulativos necessários para que um determinado acionista ou grupo de acionistas seja reconhecido como controlador de uma companhia: (i) a titularidade de ações que lhe assegurem, de modo permanente, (a) a maioria dos votos nas deliberações da assembleia e (b) a eleição da maioria dos administradores da companhia; e (ii) o uso efetivo desse seu poder para dirigir as atividades sociais da companhia.

Percebe-se, portanto, que a configuração do poder de controle não depende apenas de uma definição jurídica do termo, mas especialmente da verificação de elementos de fato. A caracterização do acionista controlador figura esta que vai além da figura do acionista majoritário, que simplesmente detém a maior parte das ações votantes de uma companhia - exige a circunstância fática de que ele efetivamente exerça o controle: além de ser titular dos direitos de sócio que lhe permitam dirigir ou eleger quem irá dirigir a companhia, o controlador deve efetivamente dirigi-la ou eleger a maioria dos administradores, manifestando a vontade prevalecente nas deliberações sociais. É ele o verdadeiro dirigente dos negócios sociais, aquele que manifesta a vontade prevalecente nas votações das assembleias gerais e na eleição dos administradores da companhia. ${ }^{21}$

Observa-se também que a Lei $\mathrm{n}^{\circ} 6.404 / 76$, ao impor a titularidade de direitos de sócio como pressuposto de caracterização da figura do acionista controlador - limitando-se, pelo menos em tese, a reconhecer apenas o controle acionário - excluiu os casos de controle gerencial e controle externo. Nestes casos, portanto, não existe, aos olhos da Lei das S.A., a figura do acionista controlador na companhia, não sendo aplicáveis os dispositivos que tratam da

\footnotetext{
${ }^{20}$ CARVALHOSA, Modesto. Comentários à lei de sociedades anônimas: arts. 243 a 300. $5^{\mathrm{a}}$ ed.. São Paulo: Saraiva, 2011. p. 218.

${ }^{21}$ EIZIRIK, Nelson. Direito Societário: Estudos e Pareceres. São Paulo: Quartier Latin, 2015. p. 413414.
} 
responsabilidade do controlador, tais como os artigos 116, parágrafo único e 117, ou da obrigatoriedade de oferta pública no caso de alienação de controle disposta no artigo 254-A, entre outros. ${ }^{22}$

A noção de "acionista controlador" trazida pela Lei n" 6.404/76 reconhece o papel diferenciado que exerce o acionista controlador em relação àquele dos demais acionistas da companhia. A importância de identifica-lo está relacionada às implicações disso no rumo dos negócios sociais, uma vez que é ele quem os comanda, expressando a vontade da companhia.

Por isso, a Lei das S.A. reconhece o poder de controle e constitui nele, nos termos do parágrafo único do seu artigo 116, um poder vinculado à realização dos objetos e da função social da Companhia, atribuindo ao seu titular a consecução de determinadas finalidades, deveres e responsabilidades para com os demais acionistas, os empregados e a comunidade:

Art. 116. [...] Parágrafo único. O acionista controlador deve usar o poder com o fim de fazer a companhia realizar o seu objeto e cumprir sua função social, e tem deveres e responsabilidades para com os demais acionistas da empresa, os que nela trabalham e para com a comunidade em que atua, cujos direitos e interesses deve lealmente respeitar e atender.

O acionista controlador determina as deliberações da Assembleia Geral, dirige as atividades sociais e orienta o funcionamento dos órgãos da companhia, sendo submetido a diversas regras de comportamento e sanções próprias.

O parágrafo único do artigo 116 e o artigo 117 da Lei das S.A, a contrario sensu, constituem verdadeiros deveres fiduciários do acionista controlador, decorrentes da responsabilidade direta que o mesmo assume na condução dos negócios sociais. Tratam-se de deveres amplos, não sujeitos a enumeração exaustiva. ${ }^{23}$ Confira-se o teor do artigo 117 :

\footnotetext{
${ }^{22}$ EIZIRIK, Nelson. Lei das S.A comentada: artigos 80 ao 137. $2^{\mathrm{a}}$ ed.. São Paulo: Quartier Latin, 2015. p. 232.

${ }^{23}$ SALOMÃO FILHO, Calixto. O novo direito societário. $3^{\text {a }}$ ed.. São Paulo: Malheiros Editores, 2006. p. 171.
} 
Art. 117. O acionista controlador responde pelos danos causados por atos praticados com abuso de poder.

$\S 1^{\circ}$ São modalidades de exercício abusivo de poder:

a) orientar a companhia para fim estranho ao objeto social ou lesivo ao interesse nacional, ou levá-la a favorecer outra sociedade, brasileira ou estrangeira, em prejuízo da participação dos acionistas minoritários nos lucros ou no acervo da companhia, ou da economia nacional;

b) promover a liquidação de companhia próspera, ou a transformação, incorporação, fusão ou cisão da companhia, com o fim de obter, para si ou para outrem, vantagem indevida, em prejuízo dos demais acionistas, dos que trabalham na empresa ou dos investidores em valores mobiliários emitidos pela companhia;

c) promover alteração estatutária, emissão de valores mobiliários ou adoção de políticas ou decisões que não tenham por fim o interesse da companhia e visem a causar prejuízo a acionistas minoritários, aos que trabalham na empresa ou aos investidores em valores mobiliários emitidos pela companhia;

d) eleger administrador ou fiscal que sabe inapto, moral ou tecnicamente;

e) induzir, ou tentar induzir, administrador ou fiscal a praticar ato ilegal, ou, descumprindo seus deveres definidos nesta Lei e no estatuto, promover, contra o interesse da companhia, sua ratificação pela assembléia-geral;

f) contratar com a companhia, diretamente ou através de outrem, ou de sociedade na qual tenha interesse, em condições de favorecimento ou não equitativas;

g) aprovar ou fazer aprovar contas irregulares de administradores, por favorecimento pessoal, ou deixar de apurar denúncia que saiba ou devesse saber procedente, ou que justifique fundada suspeita de irregularidade.

h) subscrever ações, para os fins do disposto no art. 170, com a realização em bens estranhos ao objeto social da companhia.

$\S 2^{\circ}$ No caso da alínea e do $\S 1^{\circ}$, o administrador ou fiscal que praticar o ato ilegal responde solidariamente com o acionista controlador.

$\S 3^{\circ} \mathrm{O}$ acionista controlador que exerce cargo de administrador ou fiscal tem também os deveres e responsabilidades próprios do cargo.

Inclusive, acreditando no caráter aberto do artigo $117^{24}$, a CVM baixou a Instrução $n^{\circ} 323 / 00^{25}$, em que são acrescidos mais 15 incisos indicando novas modalidades de abuso de poder.

Essa distinção entre as obrigações conferidas ao acionista controlador e aquelas conferidas aos demais acionistas se dá justamente pela diferença de posição ocupada por cada um na companhia o que, por sua vez, implica na

\footnotetext{
${ }^{24}$ AMENDOLARA, Leslie. Direito dos Acionistas Minoritários. $3^{\mathrm{a}}$ ed.. São Paulo: Quartier Latin, 2012. p. 142.

${ }^{25} \mathrm{CVM}$, Instrução ${ }^{\circ} 323$, de 19 de janeiro de 2000. Define hipóteses de exercício abusivo do poder de controle e de infração grave. Disponível em <http://www.cvm.gov.br/legislacao/instrucoes/inst323.html>. Acesso em 16 mai. 2019.
} 
possibilidade dos mesmos divergirem em relação aos seus interesses e prioridades no âmbito da companhia. Sendo o acionista controlador titular de um número maior de ações, consegue impor sua vontade nas deliberações sociais, fazendo com que o seu interesse prevaleça.

Nelson Eizirik ${ }^{26}$ fala em um "potencial conflito de interesses", que pode ser reduzido mediante cláusulas estatutárias que protejam os acionistas não controladores. E a Lei das S.A., visando reduzir os custos da negociação caso a caso de cláusulas estatutárias, prevê genericamente determinados direitos - que serão detalhados mais adiante - dos quais os acionistas não podem ser privados, nem por Assembleia Geral ou dispositivo estatutário, funcionando como limite ao poder de controle.

\subsection{O prêmio de controle}

O mercado atribui ao bloco de controle valor maior do que a simples soma do valor das ações que o integram. O valor atribuído ao poder de controle é essencialmente distinto do mero valor econômico das ações, consideradas cada uma per se: não é a soma do valor das ações como coisas singulares, mas do bloco de controle como coisa coletiva, contendo o poder de dirigir a companhia. ${ }^{27}$ Nesse sentido:

O valor do controle é, por definição, a diferença entre o valor das ações que integram o bloco de controle, consideradas como coisas singulares, e o valor que algum investidor está disposto a pagar pelo bloco de controle. Não pode ser determinado, portanto, em função do valor das ações, segundo qualquer dos critérios utilizados para avaliá-las, mas somente com base em negociações no mercado e preço efetivamente pago ou, ao menos, ofertado. ${ }^{28}$

\footnotetext{
${ }^{26}$ EIZIRIK, Nelson. Lei das S.A comentada: artigos 80 ao 137. $2^{\mathrm{a}}$ ed.. São Paulo: Quartier Latin, 2015. p. 139-140.

${ }^{27}$ LAMY FILHO, Alfredo; PEDREIRA, José Bulhões (Coord.). Direito das Companhias. Rio de Janeiro: Forense, 2009. p. 832.

${ }^{28}$ Ibid. p. 2003.
} 
Na prática, esse valor próprio se materializa nas transações de controle, notadamente na alienação privada de controle, em que o acionista controlador transfere para um terceiro as ações que, em bloco, permitem que seu titular exerça o controle da companhia. Ao adquirir o bloco de ações de controle, o investidor passa não somente a ter o direito de participar dos lucros e usufruir dos demais direitos atribuídos a todos os acionistas como consegue comandar a companhia. ${ }^{29}$ Por isso, os potenciais adquirentes dessas ações se dispõem a pagar por elas um valor adicional ao que pagariam se comprassem uma por uma, separadamente. ${ }^{30}$

Esse valor adicional, comumente denominado "prêmio de controle", é reconhecido pela Lei das S.A., que determina, no caput do seu artigo 254-A, a extensão desse prêmio, na proporção de $80 \%$, aos demais titulares de ações votantes, mediante oferta pública de aquisição de ações.

\subsubsection{A quem pertence o prêmio de controle?}

Na doutrina, há quem sustente que o valor do poder de controle deve ser estendido a todos os acionistas da companhia: tanto aos titulares de ações com direito de voto quanto aos titulares de ações sem direito de voto ou com voto restrito.

De acordo com Adolph Berle e Gardiner Means, o poder de controle é um bem da companhia, e o pagamento por esse poder deve se destinar à tesouraria da empresa. ${ }^{31}$

\footnotetext{
${ }^{29}$ PENNA, Paulo Eduardo. Alienação de controle de companhia aberta. In: COELHO, Fábio Ulhoa (Coord.). Tratado de direito comercial: relações societárias e mercado de capitais. São Paulo: Saraiva, 2015. p. 298-299.

${ }^{30}$ Supondo o capital social de uma companhia é constituído de 100 ações votantes. O valor de mercado de cada ação votante equivale a $\mathrm{R} \$ 1,00$. No entanto, se um acionista titular de 55 dessas ações decide aliena-las, o preço de venda dessas ações, em bloco, é superior a $\mathrm{R} \$ 55,00$ : os interessados aceitarão pagar mais do que R $\$ 1,00$ por ação se forem adquirir todas as 55 ações em conjunto, uma vez que o novo adquirente não se tornará apenas acionista da companhia, mas controlador da mesma.

${ }^{31}$ BERLE, Adolf A.; MEANS, Gardiner C. A moderna sociedade anônima e a propriedade privada. Tradução de Dinah de Abreu Azevedo. São Paulo: Abril Cultural, 1984. p. 201.
} 
Para Norma Parente, a justificativa está no fato de que, em termos patrimoniais, a contribuição de todos acionistas - sejam eles preferenciais ou ordinários, sejam eles controladores ou não - tem o mesmo valor. A valorização das ações deve refletir a participação no patrimônio social e se, tanto no momento de subscrição quanto no de divisão do patrimônio pelo número de ações não se atribui maior valor às ações do controlador, ele também não deve usufruir exclusivamente do prêmio de controle. ${ }^{32}$

Nelson Cândido Motta, por sua vez, afirma que estabelecer diferenças entre os acionistas preferenciais e os acionistas ordinários, no caso de alienação de controle, significa admitir que há uma desigualdade de direitos patrimoniais entre eles, conferindo ao direito de voto uma qualificação privilegiada no acesso aos procedimentos legais de proteção de minoria. Inclusive, o autor faz fortes críticas à Resolução CMN n 401/76, que limitou a obrigação de oferta pública apenas aos acionistas com direito de voto, sendo que a Lei das S.A., em seu artigo 254 então vigente, não fazia essa diferenciação, não podendo um ato administrativo fazê-lo, sob pena de "ser averbado de arbitrário, injurídico e ilegal". 33

Outra corrente, que parece ter prevalecido quando da edição do artigo 254-A, entende que o prêmio de controle deve ser repartido entre todos os titulares de ações da mesma espécie e classe que aquelas integrantes do bloco de controle. Como as ações do bloco de controle são aquelas com direito a voto, significa dizer que o compartilhamento do prêmio se restringiria aos acionistas controladores e os demais acionistas com direito de voto.

William D. Andrews, baseando-se na tese de Berle e Means, desenvolveu a chamada "equal opportunity rule", uma teoria fundamentada na igualdade de

\footnotetext{
${ }^{32}$ PARENTE, Norma. Principais inovações introduzidas pela Lei n. 10.303, de 31 de outubro de 2001, à Lei das Sociedades por Ações. In: LOBO, Jorge (Coord.). Reforma da Lei das Sociedades Anônimas. São Paulo: Forense, 2002. p. 39-40.

${ }^{33}$ MOTTA, Nelson Candido. Alienação de controle de instituições financeiras. Acionistas Minoritários. Notas para uma interpretação sistemática da Lei das S.A. Revista de Direito Mercantil, Industrial, Econômico e Financeiro. São Paulo, n. 46, p. 41, ano XXIV, jul./set. 1985.
} 
oportunidade: o controlador pode alienar suas ações pelo preço e nas condições que desejar, contanto que todos os acionistas com ações de espécie e classe iguais tenham a oportunidade de aliená-las nos mesmo termos e condições. ${ }^{34}$

Há quem acredite, como Arnoldo Wald, que as noções de maioria e minoria só fazem sentido com relação a ações com direito a voto, porque somente os titulares destas possuem uma posição política na companhia e guardam alguma relação com o controle da companhia. $\mathrm{O}$ tratamento igualitário visado só pode ser conferido àqueles que possuem ações idênticas às do controlador. ${ }^{35}$

A União Europeia seguiu nessa linha: a Diretiva 2004/25/CE do Parlamento Europeu e do Conselho da União Europeia, de 21 de abril de 2004, estabelece que a pessoa que adquirir uma determinada porcentagem dos direitos de voto de uma companhia que lhe permita dispor do controle da mesma, deve lançar uma oferta para aquisição das ações dos demais acionistas com direito de voto:

Artigo $2^{\circ}$. Definições

1. Para efeitos da presente directiva, entende-se por: [...] e) «Valores mobiliários»: títulos negociáveis que conferem direitos de voto numa sociedade.

Artigo $5^{\circ}$. Protecção dos accionistas minoritários; oferta obrigatória; preço equitativo 1. Sempre que uma pessoa singular ou colectiva, na sequência de uma aquisição efectuada por si ou por pessoas que com ela actuam em concertação, venha a deter valores mobiliários de uma sociedade a que se refere $\mathrm{o} \mathrm{n} .^{\circ} 1$ do artigo $1 .^{\circ}$ que, adicionados a uma eventual participação que já detenha e à participação detida pelas pessoas que com ela actuam em concertação, lhe confiram directa ou indirectamente uma determinada percentagem dos direitos de voto nessa sociedade, permitindo-lhe dispor do controlo da mesma, os Estados-Membros asseguram que essa pessoa deva lançar uma oferta a fim de proteger os accionistas minoritários dessa sociedade. Esta oferta deve ser dirigida o mais rapidamente possível a todos os titulares de valores

\footnotetext{
${ }^{34}$ ANDREWS, William D. The stockholder's right to equal opportunity in the sale of shares. Harvard Law Review, n. 3, 1965, p. 515 apud PENNA, Paulo Eduardo. Alienação de controle de companhia aberta. In: COELHO, Fábio Ulhoa (Coord.). Tratado de direito comercial: relações societárias e mercado de capitais. São Paulo: Saraiva, 2015. p. 301.

${ }^{35}$ WALD, Arnoldo. Do descabimento da oferta pública de compra em relação às ações preferenciais. Revista de Direito Mercantil, Industrial, Econômico e Financeiro. São Paulo, n. 45, p. 9, ano XXI, jan./mar. 1982.
} 
mobiliários, para a totalidade das suas participações, a um preço equitativo definido no n. ${ }^{\circ} 4{ }^{36}$

A Diretiva deixa aos Estados-Membros definirem o percentual presuntivo de posição de controle. Na Suécia, o percentual é de 40\%; no Reino Unido, Alemanha, Áustria, Itália e Holanda, é de 30\%; na França, o percentual é de $33 \%$; já na Espanha, é de $25 \% .{ }^{37}$

Por fim, há quem entenda que o valor atribuído ao poder de controle pertence exclusivamente ao(s) acionista(s) controlador(es).

Fábio Konder Comparato questionou a lógica de se compartilhar o valor do controle - que, como se sabe, tem um valor próprio - com os acionistas não controladores, que não assumem as responsabilidades decorrentes do poder de controle: o status de acionista controlador não se confunde com o de não controlador. ${ }^{38}$

Alfredo Lamy Filho e José Luiz Bulhões Pedreira, redatores da Lei $\mathrm{n}^{\circ}$ 6.404/76, se manifestaram inúmeras vezes contra o compartilhamento do valor do prêmio de controle com acionistas não controladores, que vinha sendo formulado em diversas emendas apresentadas por Deputados e Senadores dentre elas, a Emenda Lehmann, que, conforme se verá mais adiante, levou à inclusão do (atualmente revogado) artigo 254 da Lei das S.A.

Para os autores, (a) toda economia de mercado atribui valor econômico ao bloco de controle da companhia, que assegura ao seu titular o poder de determinar o destino da empresa, escolher seus administradores e definir suas políticas, (b) o valor do controle integra o patrimônio do controlador, e não da companhia, e (c) os casos de venda do controle de instituições financeiras, que,

\footnotetext{
${ }^{36}$ UNIÃO EUROPEIA. Directiva 2004/25/CE, relativa às ofertas públicas de aquisição, 21 abr. 2004. Disponível em <https://eur-lex.europa.eu/legal-content/PT/TXT/?uri=celex:32004L0025>. Acesso 12 mai 2019.

${ }^{37}$ MUNHOZ, Eduardo Secchi. Aquisição de controle na sociedade anônima. São Paulo: Saraiva, 2013, p. 252.

${ }^{38}$ COMPARATO, Fábio Konder; SAlOMÃO FILHO, Calixto. O Poder de Controle na Sociedade Anônima. $5^{\text {a }}$ ed.. Rio de Janeiro: Editora Forense, 2008. p. 310-311.
} 
conforme será visto mais à frente, serviram de fundamento para a elaboração do revogado artigo 254 da Lei das S.A., por conferirem aos controladores que alienavam suas ações ganhos desmesurados em detrimento dos minoritários, apresentavam circunstâncias peculiares, não devendo ser justificativa para a participação dos minoritários no valor de alienação do controle. ${ }^{39}$

Também o item $d$ da Mensagem 204 - Exposição de Motivos da Lei ${ }^{\circ}$ 6.404/76 declarava que, uma vez que os controladores possuíam responsabilidades próprias definidas na lei, das quais os minoritários não partilhavam, seria incoerente tanto não atribuir um valor econômico ao bloco de controle, quanto estender aos minoritários esses benefícios econômicos. ${ }^{40}$

Esse entendimento é bem presente no direito estrangeiro, especialmente no norte-americano. Juristas como Henry G. Manne, Frank H. Easterbrook, Daniel R. Fischel e Richard Allen Posner, seguindo uma linha liberal, pregaram pela maior liberdade possível do mercado de controle societário, pois entendiam que este se acomoda via preço. ${ }^{41}$

Outros, como Richard W. Jennings, Harold Marsh Jr. e John C. Coffe Jr., também entendem que os acionistas controladores são livres para vender suas ações prelo preço que quiserem e a qualquer pessoa que se disponha a adquirilas, mas propõem, como único obstáculo a essa liberdade de alienar, normas de full and fair disclosure e de vedação à prática de insider trading. No caso de alienação de controle em circunstâncias que por si só sejam ilícitas ou causem danos aos minoritários, o controlador deverá ser responsabilizado. ${ }^{42}$

Apesar de algumas decisões judiciais a favor da repartição do prêmio de controle entre os minoritários, esta teoria não foi consagrada nem na legislação e nem jurisprudência dos Estados Unidos, prevalecendo a regra da livre

\footnotetext{
${ }^{39}$ LAMY FILHO, Alfredo; PEDREIRA, José Bulhões (Coord.). Direito das Companhias. Rio de Janeiro: Forense, 2009. p. 2006-2007.

${ }^{40}$ PRADO, Roberta Nioac. Oferta Pública de ações obrigatórias nas S.A..São Paulo: Quartier Latin, 2005. p. 330.

${ }^{41}$ Ibid. p. 327.

${ }^{42}$ Ibid. p. 328.
} 
transferência do controle. ${ }^{43}$ Nos termos do acórdão paradigma proferido em 1979 no caso Zetlin vs. Hanson Holdings, Inc., "o prêmio é o preço que o investidor paga para ter o privilégio de influenciar a companhia e a sua gestão. Em contrapartida, é o preço que o controlador recebe para abrir mão desse privilégio". Isso não impede, por óbvio, a responsabilização do acionista controlador que alienar o controle em circunstâncias ilícitas ou causem dano aos minoritários da companhia. ${ }^{44}$

Outro entendimento interessante é o de Luiz Leonardo Cantidiano. Segundo o autor, o prêmio de controle decorrente da alienação privada de controle pertence, a princípio, ao acionista controlador. Somente nos casos em que houver posterior incorporação da companhia que o prêmio deverá ser estendido - estendido a todos os acionistas da companhia, votantes e não votantes, pois "o negócio repercute necessária e inevitavelmente na esfera do interesse jurídico e patrimonial de todos os acionistas, e não apenas daqueles que integram a mesma espécie da classe do acionista controlador". ${ }^{45}$ No entanto, cabe ressaltar que neste caso os acionistas teriam direito de recesso, nos termos dos artigos 136, IV e 137 da Lei das S.A.

\footnotetext{
${ }^{43}$ PENNA, Paulo Eduardo. Alienação de controle de companhia aberta. In: COELHO, Fábio Ulhoa (Coord.). Tratado de direito comercial: relações societárias e mercado de capitais. São Paulo: Saraiva, 2015. p. 302.

${ }^{44}$ PRADO, Roberta Nioac. Oferta Pública de ações obrigatórias nas S.A.. São Paulo: Quartier Latin, 2005. p. 328.

${ }^{45}$ CANTIDIANO, Luiz Leonardo. Alienação e aquisição de controle. Revista de Direito Mercantil, Industrial, Econômico e Financeiro. São Paulo, n. 59, p. 56-67, ano XXIV, jul./set. 1985.
} 


\section{Capítulo 2. 0 acionista minoritário}

O conceito de acionista minoritário não é absoluto. Isso se dá em razão do caráter relativo dos termos maioria e minoria, que podem variar dependendo dos diferentes casos concretos que ocorrem no seio da companhia. ${ }^{46}$

Além disso, há quem considere acionista minoritário apenas os titulares de ações com direito de voto que não integram o bloco de controle. Outros consideram como minoritário todos os acionistas da companhia - ou seja, titulares de ações com ou sem direito de voto - que não sejam controladores. ${ }^{47}$

Independentemente da corrente que se entende como correta, este estudo trata do acionista minoritário como aquele que possui ações com direito de voto que não fazem parte do bloco de controle, e considera como acionistas não controladores todos os acionistas da companhia - ordinários e preferenciais não integrantes do bloco de controle.

As obrigações legais impostas aos acionistas não controladores se limitam à integralização do preço de emissão das ações subscritas (artigo 106) e, no caso de possuírem direito de voto (ou seja, os acionistas minoritários), o exercício do direito de voto na Assembleia Geral no interesse da companhia (art. 115) - obrigações estas que também tem de ser observadas pelo acionista controlador.

Isso não exclui, evidentemente, a possibilidade de surgirem outras obrigações no seio de determinada companhia por meio do Estatuto Social, as quais vinculam os acionistas no sentido de fazer ou de se abster de certos atos

\footnotetext{
${ }^{46}$ LOBO, Jorge. Direito dos Acionistas. Rio de Janeiro: Elsevier, 2011, p. 41.

47 “A própria Lei 6.404/76 em seus 300 artigos não é unívoca no tratamento do conceito das minorias, às vezes referindo-se a elas sob a expressão Capital Social para dizer que também detêm aqueles direitos os preferencialistas" (AMENDOLARA, Leslie. Direito dos Acionistas Minoritários. $3^{\text {a }}$ ed.. São Paulo: Quartier Latin, 2012. p. 23).
} 
(contanto que sejam compatíveis com a natureza jurídica da sociedade anônima). ${ }^{48}$

Em compensação, o rol de direitos conferidos a esses acionistas, inclusive para se resguardarem contra possíveis decisões tomadas pelo controlador, é bem mais extenso.

\subsection{A proteção aos acionistas minoritários}

O mercado de capitais possui grande relevância na economia de um país. Os títulos ali negociados permitem a circulação de capital para financiar investimentos no setor produtivo que, por sua vez, propulsionam o crescimento econômico e, por consequência, o aumento de renda. ${ }^{49}$

O mercado de capitais brasileiro conheceu, na década de 1990, uma aceleração do movimento de abertura da economia brasileira e a crescente globalização dos negócios, levando à privatização de diversas empresas estatais e ao aumento do volume de atuação de investidores estrangeiros no país. ${ }^{50}$

Contudo, ao final dos 1990, o mercado de capitais brasileiro ainda não tinha se desenvolvido plenamente, tanto em razão da conjuntura econômica nacional e mundial, mas também pela falta de transparência na gestão e a ausência de instrumentos adequados de supervisão das companhias, o que ocasionava incertezas em relação às aplicações financeiras dos investidores. ${ }^{51}$

Vale ressaltar que tal cenário não é exclusivo do Brasil: no início do século XXI, embora o mercado de capitais norte-americano já fosse mais desenvolvido e possuísse normas mais sofisticadas, companhias norte-

\footnotetext{
${ }^{48}$ CAMPINHO, Sérgio. Curso de direito comercial: sociedade anônima. $2^{\mathrm{a}}$ ed.. São Paulo: Saraiva, 2017. p. 207.

${ }^{49}$ PERIN JUNIOR, Ecio. A Lei n. 10.303/2001 e a proteção do acionista minoritário. São Paulo: Saraiva, 2004, p. 84.

50 HISTÓRIA do Mercado de Capitais. Portal do Investidor. Disponível em <http://www.investidor.gov.br/menu/Menu_Academico/O_Mercado_de_valores_mobiliarios_brasileir o/Historia_Mercado-Capitais.html>. Acesso em 12 mai. 2019.

${ }^{51}$ Ibid. Acesso em 12 mai. 2019.
} 
americanas foram alvo de escândalos relacionados a abusos cometidos na remuneração de executivos e em contratos com partes relacionadas, além de fraudes em demonstrações financeiras. O caso mais conhecido foi o da companhia de energia americana Euron, que teve sua falência decretada, com suposta conivência da empresa de auditoria Arthur Andersen, que foi dissolvida. ${ }^{52}$

Tais acontecimentos levaram à promulgação da Lei Sarbanes-Oxley nos Estados Unidos e à intensificação dos esforços para a uniformização internacional de práticas contábeis e institucionais que visassem a ética e a transparência. ${ }^{53}$

No Brasil, foi criada a Lei $\mathrm{n}^{\circ} 10.303 / 01$, que alterou alguns aspectos da Lei $n^{\circ} 6.404 / 76$ e da Lei ${ }^{\circ} 6.385 / 76^{54}$, visando o fortalecimento do mercado de capitais e o estímulo à maior participação dos investidores, com o incremento de direitos e da proteção dos acionistas minoritários. ${ }^{55}$ Paralelamente, foram criados níveis diferenciados de prática de Governança Corporativa pela Bolsa de Valores de São Paulo (Bovespa) existente na época, e que subsistem atualmente na B3.

\subsubsection{Direitos conferidos pela Lei das S.A.}

Dentre os direitos atualmente conferidos aos acionistas minoritários de companhia aberta, temos os direitos ditos essenciais, que decorrem da lei e são inerentes à qualidade de acionista, ou seja, se aplicam a todos os acionistas da

52 CARVAlHOSA, Modesto; KUYVEN, Luiz Fernando Martins. Sociedades anônimas. In: CARVALHOSA, Modesto (Coord.). Tratado de Direito Empresarial. São Paulo: Revista dos Tribunais, 2016. v. 3. p. 75.

${ }^{53}$ Ibid. p. 75.

${ }^{54}$ BRASIL. Lei $n^{\circ}$ 6.385, de 7 de dezembro de 1976. Dispõe sobre o mercado de valores mobiliários e cria a Comissão de Valores Mobiliários. Disponível em <http://www.planalto.gov.br/ccivil_03/leis/16385.htm>. Acesso em 17 mai. 2019.

55 HISTÓRIA do Mercado de Capitais. Portal do Investidor. Disponível em <http://www.investidor.gov.br/menu/Menu_Academico/O_Mercado_de_valores_mobiliarios_brasileir o/Historia_Mercado-Capitais.html>. Acesso em 12 mai. 2019. 
companhia, não podendo o Estatuto Social nem a Assembleia Geral privar o acionista de exercê-los. São considerados direitos individuais ou próprios, para os quais não se permite modificação ou supressão pela vontade coletiva, expressa pela voz da maioria: não pode a companhia dispor daquilo que pertence individualmente ao patrimônio intangível do acionista. ${ }^{56}$ Encontram-se enunciados no artigo 109 da Lei das S.A:

Art. 109. Nem o estatuto social nem a assembléia-geral poderão privar o acionista dos direitos de:

I - participar dos lucros sociais;

II - participar do acervo da companhia, em caso de liquidação;

III - fiscalizar, na forma prevista nesta Lei, a gestão dos negócios sociais;

IV - preferência para a subscrição de ações, partes beneficiárias conversíveis em ações, debêntures conversíveis em ações e bônus de subscrição, observado o disposto nos artigos 171 e 172;

V - retirar-se da sociedade nos casos previstos nesta Lei.

Sérgio Campinho acrescenta à lista os direitos à informação e à igualdade de tratamento. ${ }^{57}$

Vale ressaltar que, no que toca ao direito de participar dos lucros sociais, a Lei das S.A. consagra em seu artigo $202^{58}$ a regra do dividendo obrigatório: os

${ }^{56}$ CAMPINHO, Sérgio. Curso de direito comercial: sociedade anônima. $2^{\mathrm{a}}$ ed.. São Paulo: Saraiva, 2017. p. 213-214.

${ }^{57}$ Ibid. p. 215.

${ }^{58}$ Art. 202. Os acionistas têm direito de receber como dividendo obrigatório, em cada exercício, a parcela dos lucros estabelecida no estatuto ou, se este for omisso, a importância determinada de acordo com as seguintes normas:

I - metade do lucro líquido do exercício diminuído ou acrescido dos seguintes valores:

a) importância destinada à constituição da reserva legal (art. 193);

b) importância destinada à formação da reserva para contingências (art. 195) e reversão da mesma reserva formada em exercícios anteriores;

II - o pagamento do dividendo determinado nos termos do inciso I poderá ser limitado ao montante do lucro líquido do exercício que tiver sido realizado, desde que a diferença seja registrada como reserva de lucros a realizar (art. 197);

III - os lucros registrados na reserva de lucros a realizar, quando realizados e se não tiverem sido absorvidos por prejuízos em exercícios subseqüentes, deverão ser acrescidos ao primeiro dividendo declarado após a realização.

$\S 1^{\circ} \mathrm{O}$ estatuto poderá estabelecer o dividendo como porcentagem do lucro ou do capital social, ou fixar outros critérios para determiná-lo, desde que sejam regulados com precisão e minúcia e não sujeitem os acionistas minoritários ao arbítrio dos órgãos de administração ou da maioria.

$\S 2$ o Quando o estatuto for omisso e a assembléia-geral deliberar alterá-lo para introduzir norma sobre a matéria, o dividendo obrigatório não poderá ser inferior a $25 \%$ (vinte e cinco por cento) do lucro líquido ajustado nos termos do inciso I deste artigo. [...] 
acionistas têm direito de participar, a cada exercício, nos lucros da companhia. O Estatuto Social não pode prever participação menor do que $25 \%$ do lucro líquido do exercício e, caso seja omisso sobre o tema, a lei estabelece o percentual de $50 \%$.

Já os direitos modificáveis, também denominados coletivos ou sociais, predominam sobre o interesse particular de cada membro da sociedade, encontrando-se estritamente ligados à vida e ao funcionamento da companhia. São todos aqueles que não vêm arrolados como essenciais em lei. Decorrem da lei ou do Estatuto Social, podem ser estendidos a todas as ações ou apresentar exclusão em relação a uma ou mais classes, assim como admitem, em alguns casos, modificações por previsão estatutária ou até mesmo pela Assembleia Geral (reformando o Estatuto). ${ }^{59}$

Além disso, tem-se presente na Lei das S.A. diversos instrumentos de atuação à disposição dos acionistas minoritários, de modo a assegurar-lhes certos poderes ${ }^{60}$, em alguns casos mediante determinadas condições (por exemplo, titularidade de um percentual mínimo de ações), tais como: (i) o processo do voto múltiplo (artigo 141, caput), (ii) o direito de pedir a instalação do Conselho Fiscal (artigo 161, §2 e Instrução CVM n ${ }^{\circ} 324 / 00^{61}$ ), (iii) o direito de eleger, em separado, um membro e respectivo suplente do Conselho de Administração (artigo 141, $\$^{\circ}$ ) e do Conselho Fiscal (artigo 161, §4 $4^{\circ}$ ), (iv) o poder de convocar, em certas circunstâncias, a Assembleia Geral, (v) a prerrogativa de exigir a exibição integral dos livros da companhia (artigo 105), (vi) a aquisição de direito de voto das ações preferenciais em caso de não pagamento dos dividendos fixos ou mínimos que fizerem jus (artigo $111, \S 1^{\circ}$ ).

${ }^{59}$ CAMPINHO, Sérgio. Curso de direito comercial: sociedade anônima. $2^{\mathrm{a}}$ ed.. São Paulo: Saraiva, 2017. p. 214.

${ }^{60}$ BORBA, José Edwaldo Tavares. Direito societário. 13a ed.. Rio de Janeiro: Renovar, 2012. p. 371.

${ }^{61} \mathrm{CVM}$, Instrução $n^{\circ} 324$, de 19 de janeiro de 2000. Fixa escala reduzindo, em função do capital social, as porcentagens mínimas de participação acionária necessárias ao pedido de instalação de Conselho Fiscal de companhia aberta previsto no § 2o do art. 161 da Lei no 6.404, de 15 de dezembro de 1976. Disponível em <http://www.cvm.gov.br/legislacao/instrucoes/inst324.html>. Acesso em 17 mai. 2019. 
Existe, ainda, a possibilidade de os minoritários celebrarem um acordo de acionistas (artigo 118), estabelecendo, por exemplo, determinadas orientações a serem seguidas no exercício de direito de voto, a fim de aglutinar o voto de vários minoritários e atingir os percentuais de ações necessários em uma deliberação na Assembleia-Geral ou à prática de certos direitos (por exemplo, a instalação do Conselho Fiscal).

Por fim, como mais um mecanismo de proteção, tem-se a Oferta Pública de Ações obrigatória, que deverá ser formulada nos casos de (i) cancelamento de registro/fechamento do capital da companhia, a todos os acionistas, (ii) aumento de participação do acionista controlador, através da aquisição de novas ações, em determinada espécie ou classe, a todos os demais titulares de ações da classe ou espécie afetadas, e (iii) alienação de controle, aos acionistas com direito de voto. Tais hipóteses estão previstas, respectivamente, no artigo $4^{\circ}, \S \S$ $4^{\circ}$ e $6^{\circ}$ e no artigo 254-A da Lei das S.A. e possuem regulamentação específica pela Instrução no 361/02 da CVM.

E, na hipótese de violação de seus direitos ou abuso de poder (pelo acionista controlador ou mesmo pelos administradores da Companhia), os acionistas minoritários e preferenciais podem fazer uso de instrumentos judiciais e administrativos, tais como a propositura de ação indenizatória ou anulatória e a apresentação de reclamação à CVM. ${ }^{62}$

\footnotetext{
62 "A sanção primeira e natural é a anulação da deliberação da Assembléia Geral estranha ao interesse da companhia. Pode ocorrer, no entanto, que o ato abusivo não comporte tal sanção (como quando, por exemplo, não reveste a forma de deliberação) ou que ela (anulação) não baste para compor os prejuízos causados à sociedade e aos minoritários. E, como destaca Dominique Schmidt (ob. cit., p. 1 84), acontece, em alguns casos, que a anulação, "esta projeção do passado no futuro", não desfaça os efeitos danosos da deliberação até o dia de sua anulação. Daí a sanção da reparação das perdas e danos inegavelmente dificeis de apurar -, que complementa, sempre que possível, a anulação, ou a substitui quando não há deliberação a anular. [...] $\mathrm{O}$ acionista controlador de companhia aberta está sujeito ainda a sanções impostas pela Comissão de Valores Mobiliários no exercício de suas atribuições de fiscalizar os mercados de valores mobiliários. A Lei n ${ }^{\circ} 6.385 / 1976$ dispõe (no art. $4^{\circ}$ ) que a CVM exercerá as atribuições previstas na lei para o fim de "proteger os titulares de valores mobiliários e os investidores do mercado contra [...] atos ilegais de administradores e acionistas controladores de companhias abertas (IV, b )." (LAMY FILHO, Alfredo; PEDREIRA, José Bulhões (Coord.). Direito das Companhias. Rio de Janeiro: Forense, 2009. p. 844-845). No mesmo sentido, cf. LOBO, Jorge. Direito dos Acionistas. Rio de Janeiro: Elsevier, 2011. p. 335 et seq.
} 


\subsubsection{Governança Corporativa}

A governança corporativa é um conjunto de regras de boas práticas de gestão, que levam a maximizar o valor da companhia para $\operatorname{todos}^{63}$, possuindo quatro pilares fundamentais: transparência (disclosure), equidade (fairness), prestação de contas (accountability) e responsabilidade corporativa (compliance). ${ }^{64}$

Além do movimento de governança corporativa ter influenciado na elaboração da Lei no 10.303/01, levou à criação, pela CVM, em junho de 2002, de uma cartilha intitulada "Recomendações da CVM sobre Governança Corporativa". ${ }^{55}$ Orientações similares já constavam do "Código das Melhores Práticas de Governança Corporativa", lançado em 1999 pelo Instituto Brasileiro de Governança Corporativa (IBGC) e estando atualmente na sua $5^{\text {a }}$ edição. ${ }^{66}$

A bolsa de valores mobiliários brasileira, atual B3, possui, além do segmento dito Básico, segmentos especiais de listagem de companhias: Novo Mercado, Nível 1, Nível 2, Bovespa Mais e Bovespa Mais Nível 2. Cada um desses segmentos especiais, cuja adesão pela companhia é voluntária, prevê, em seu Regulamento, regras de governança corporativa diferenciadas, que vão além daquelas previstas na Lei das S.A., e devem ser observadas pela companhia aderente. ${ }^{67}$

\footnotetext{
${ }^{63}$ PARENTE, Norma. Mercado de Capitais. In: CARVALHOSA, Modesto (Coord.). Tratado de Direito Empresarial. São Paulo: Revista dos Tribunais, 2016. v. 6. p. 54.

${ }^{64}$ CVM. O mercado de valores mobiliários brasileiro. $3^{\text {a }}$ ed. Rio de Janeiro: Comissão de Valores

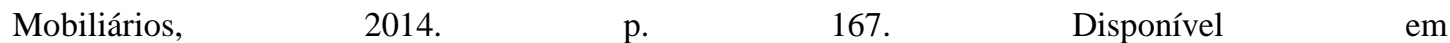
<http://www.investidor.gov.br/portaldoinvestidor/export/sites/portaldoinvestidor/publicacao/Livro/Liv roTOP-CVM.pdf>. Acesso em 12 mai. 2019.

${ }^{65}$ Ibid. Acesso em 12 mai. 2019.

66 IBGC, Código das Melhores Práticas de Governança Corporativa. Disponível em $<$ https://conhecimento.ibgc.org.br/Lists/Publicacoes/Attachments/21138/Publicacao-IBGCCodigoCodigodasMelhoresPraticasdeGC-5aEdicao.pdf>. Acesso em 11 mai. 2019.

67 B3 - Brasil, Bolsa, Balcão. Segmentos de listagem. Disponível em $<$ http://www.b3.com.br/pt_br/produtos-e-servicos/solucoes-para-emissores/segmentos-delistagem/sobre-segmentos-de-listagem/>. Acesso em 11 mai. 2019.
} 
Dentre as práticas de governança corporativa que prezam cada um dos segmentos especiais, pode-se verificar um maior número de proteções aos acionistas minoritários e regras de divulgação de informações mais detalhadas o que, por consequência, pode atrair mais investidores dispostos a aplicar seus recursos naquela companhia listada.

A propósito, os segmentos da Bovespa Mais e do Novo Mercado não admitem a emissão de ações preferenciais: as empresas listadas nesses segmentos só podem ter seu capital social formado por ações ordinárias, ou seja, com direito de voto. $\mathrm{O}$ fundamento dessa imposição parece estar na tentativa de maior participação dos acionistas - além dos controladores - nas deliberações e nos negócios da companhia. 


\section{Capítulo 3. A obrigatoriedade de OPA por alienação de controle}

\subsection{O artigo 254-A da Lei das S.A.}

\subsubsection{Antecedentes ao dispositivo}

O Decreto-lei $n^{\circ}$ 2.627/40, diploma anterior à Lei $n^{\circ}$ 6.404/76 que regulava as sociedades por ações, nada dispunha sobre a figura do acionista controlador e muito menos sobre as alienações de controle de companhia aberta. Entretanto, alguns acontecimentos anteriores à Lei no 6.404/76 trouxeram, quando da sua elaboração, uma intensa discussão em torno da necessidade de regulação das transferências de controle societário no Brasil.

A partir da década de 1950, o Governo Federal passou a adotar uma política de dificultar a aquisição de novas licenças para abertura de agências bancarias - as chamadas "cartas patentes". A sucessão nas licenças já existentes, no entanto, continuava sendo admitida. Isso fez com que os interessados em licenças bancárias, ao invés de tentarem obtê-las perante o poder público, realizassem operação de aquisição de controle de outro banco comercial, titular de cartas patentes, seguida de sua incorporação. Tendo em vista que, ao adquirir o controle de um banco para, ato contínuo, incorporá-lo, adquiria-se também as suas agências bancárias, comprador e vendedor incluíam no valor do poder de controle o valor das cartas patentes. ${ }^{68}$

Nos termos da legislação vigente à época, as ações dos demais acionistas do banco incorporado eram substituídas por ações do incorporador, segundo relação de troca estabelecida com base no valor de patrimônio líquido contábil, sem considerar os intangíveis (isto é, aquilo que pertence à companhia e,

\footnotetext{
${ }^{68}$ LAMY FILHO, Alfredo; PEDREIRA, José Bulhões (Coord.). Direito das Companhias. Rio de Janeiro: Forense, 2009. p. 2005.
} 
portanto, a todos os seus acionistas). Dessa forma, embora as cartas patentes não pertencessem ao controlador, mas sim à companhia (tratando-se de um ativo intangível), o seu valor era integralmente englobado no preço pago pelas ações do bloco de controle que, em razão disso, acabava sendo muito superior ao preço das demais ações do banco incorporado. ${ }^{69}$

Um exemplo de caso concreto é o da Santa Casa de Misericórdia, que, à época, era uma acionista minoritária do Banco do Comércio e Indústria de São Paulo S.A. O grupo controlador do banco adquiriu, em negociação direta e privada (ou seja, fora do pregão), as ações detidas pela Santa Casa de Misericórdia, por preço ligeiramente superior ao da cotação em bolsa. Dias depois, alienou a uma instituição financeira o bloco de controle juntamente às demais ações adquiridas, por preço 12 vezes superior ao pago - preço este que o grupo controlador, antes mesmo de comprar as ações da Santa Casa de Misericórdia, já tinha negociado com a instituição financeira, porém jamais divulgado, nem ao mercado nem à Santa Casa. ${ }^{70}$

Embora esses casos envolvessem questões relativas a operações de incorporação e/ou insider trading, eles dispararam grandes debates acerca da necessidade de regulação da alienação de controle de companhias abertas.

Em 1974, o Ministério da Fazenda tomou a iniciativa de promover a revisão do Decreto $n^{\circ} 2.627 / 40$, que regulava as sociedades por ações, uma vez que não correspondia mais, por uma série de razões, às demandas do mercado de capitais brasileiro. Submeteu, então, uma exposição de motivos da reforma ao Presidente da República, na qual definia diretrizes a serem observadas na elaboração do anteprojeto, dentre elas a previsão de "mecanismos que impeçam que cada ação do majoritário possua valor potencial muito superior ao de cada

\footnotetext{
${ }^{69}$ LAMY FILHO, Alfredo; PEDREIRA, José Bulhões (Coord.). Direito das Companhias. Rio de Janeiro: Forense, 2009. p. 2005-2006.

${ }^{70}$ PRADO, Roberta Nioac. Oferta Pública de Ações Obrigatória nas S.A.. São Paulo: Quartier Latin, 2005. p. 86-87.
} 
ação do minoritário" e de "um sistema de oferta pública para as transações que envolvam uma parcela substantiva da transferência do capital votante". ${ }^{71}$

O Anteprojeto da Lei das S.A., de autoria de Alfredo Lamy Filho e José Luiz Bulhões Pedreira, e o Projeto da Lei das S.A., do Poder Executivo, estabeleceram apenas o artigo 255, com o seguinte teor:

255. A alienação do controle de companhia aberta que dependa de autorização do governo para funcionar e cujas ações ordinárias sejam por força de lei, nominativas ou endossáveis, está sujeita à prévia autorização do órgão competente para aprovar a alteração do seu estatuto.

$\S 1^{\circ} \mathrm{A}$ autoridade competente para autorizar a alienação deve zelar para que seja assegurado tratamento eqüitativo aos acionistas minoritários, mediante simultânea oferta pública para a aquisição das suas ações, ou o rateio, por todos os acionistas, dos intangíveis da companhia, inclusive autorização para funcionar.

$\S 2^{\circ} \mathrm{Se}$ a compradora pretender incorporar a companhia, ou com ela se fundir, o tratamento eqüitativo referido no $\S 1^{\circ}$ será apreciado no conjunto das operações.

O dispositivo supracitado protegia os acionistas minoritários de bancos comerciais contra as operações de transferência de controle seguida de incorporação, tal como eram praticadas, impedindo que o controlador se apropriasse do valor dos intangíveis da instituição financeira. Mas não estendeu a todas as companhias abertas a participação dos acionistas minoritários no valor de alienação do controle, pois, conforme visto no item 1.3.1., os redatores, Lamy Filho e Bulhões Pedreira, defendiam a apropriação do prêmio de controle pelo acionista controlador. ${ }^{72}$

Na Câmara de Deputados foram propostas duas emendas ao artigo 255 do projeto, de autoria dos Deputados Alberto Hoffmann e Cunha Bueno, e uma emenda aditiva do Deputado Herbert Levy, que introduzia no projeto requisito da oferta pública para assegurar aos acionistas minoritários a oportunidade de

\footnotetext{
${ }^{71}$ LAMY FILHO, Alfredo; PEDREIRA, José Bulhões (Coord.). Direito das Companhias. Rio de Janeiro: Forense, 2009. p. 2006.

${ }^{72}$ Ibid. p. 2006-2007.
} 
vender suas ações ao mesmo preço unitário das ações de controle. Essas emendas foram, no entanto, rejeitadas na Câmara. ${ }^{73}$

No Senado Federal, o Senador Otto Cyrillo Lehmann apresentou outra emenda, de conteúdo semelhante, que ficou conhecida como "Emenda Lehmann". A proposta foi aprovada pelo Senado e depois pela Câmara de Deputados, vindo a constituir o artigo 254 da Lei das S.A., com o seguinte teor:

Art. 254. A alienação do controle da companhia aberta dependerá de prévia autorização da Comissão de Valores Mobiliários.

$\S 1^{\circ}$ A Comissão de Valores Mobiliários deve zelar para que seja assegurado tratamento igualitário aos acionistas minoritários, mediante simultânea oferta pública para aquisição de ações.

$\S 2^{\circ}$ Se o número de ações ofertadas, incluindo as dos controladores ou majoritários, ultrapassar o máximo previsto na oferta, será obrigatório o rateio, na forma prevista no instrumento da oferta pública.

$\S 3^{\circ}$ Compete ao Conselho Monetário Nacional estabelecer normas a serem observadas na oferta pública relativa à alienação do controle de companhia aberta.

A expressão "acionistas minoritários" deixou dúvidas e dividiu opiniões acerca de sua abrangência: os destinatários da oferta pública imposta no $\S^{\circ}$ do artigo 254 seriam apenas os acionistas com direito a voto ou todos os acionistas da companhia? A Resolução CMN nº 401/76, que veio para regulamentar as alienações de controle (em respeito ao $\S 3^{\circ}$ do artigo 254 da Lei das S.A.), limitou a obrigação de ofertar apenas aos titulares de ações com direito a voto. ${ }^{74}$

Durante a implementação do programa de privatizações, foi editada a Lei $n^{\circ}$ 9.457/97, que, em seu art. 6º revogou o art. 254 da Lei das S.A., para

\footnotetext{
${ }^{73}$ LAMY FILHO, Alfredo; PEDREIRA, José Bulhões (Coord.). Direito das Companhias. Rio de Janeiro: Forense, 2009. p. 2007.

74 "I - A alienação do controle de companhia aberta somente poderá ser contratada sob a condição, suspensiva ou resolutiva, de que o adquirente se obrigue a fazer, nos termos desta Resolução, oferta pública de aquisição das ações com direito a voto de propriedade dos demais acionistas da companhia, de modo a lhes assegurar tratamento igualitário ao do acionista controlador" (CONSELHO MONETÁRIO NACIONAL, Resolução $n^{\circ} 401$, de 22 de dezembro de 2016 (revogada). Disponível em $<$ https://www.bcb.gov.br/estabilidadefinanceira/exibenormativo?tipo=Resolu\%C3\%A7\%C3\%A3o\&n umero $=401>$. Acesso em 17 mai. 2019).
} 
viabilizar o recebimento, pela União e Estados, de todo o prêmio da alienação do controle das sociedades de economia mista privatizadas. ${ }^{75}$

A justificativa do governo foi a de que a revogação do dispositivo facilitaria as reestruturações societárias, evitando que os antigos controladores (os entes públicos) dividissem o prêmio de controle com os demais acionistas, e atraindo maior número de interessados, em vista da redução do custo da operação. ${ }^{76}$ De acordo com o autor do projeto de reforma, Deputado Antonio Kandir:

[...] a obrigatoriedade da oferta pública produz o pior dos mundos. Ao mesmo tempo inibe e dificulta processos de alienação de controle necessários ao saneamento de empresas e produz situação desfavorável aos minoritários, uma vez que o nãosaneamento de uma empresa resulta em queda do valor de suas ações, no que se prejudicam, mais que todos, os acionistas minoritários. ${ }^{77}$

Lamy Filho e Bulhões Pedreira, por sua vez, se manifestaram nos seguintes termos:

A medida é salutar e deverá concorrer para aumentar o número das companhias abertas, dado que o artigo 254 (que subordinava a alienação de controle a autorização da CVM para o fim de assegurar oferta pública aos minoritários) representou grave empecilho à abertura das companhias: é que os controladores das companhias fechadas hesitavam em recorrer ao mercado para o aumento de capital das suas empresas sabendo que, caso o fizessem, as ações que detinham passavam a ter ônus diferente das demais. ${ }^{78}$

No período de 1997 a 2001, em que vigorou a "regra de mercado", foram realizadas diversas operações com o pagamento de prêmios muito elevados aos controladores. Os minoritários permaneceram com ações com baixa liquidez ou

\footnotetext{
${ }^{75}$ LAMY FILHO, Alfredo; PEDREIRA, José Bulhões (Coord.). Direito das Companhias. Rio de Janeiro: Forense, 2009. p. 2008.

${ }^{76}$ MUNHOZ, Eduardo Secchi. Aquisição de controle na sociedade anônima. São Paulo: Saraiva, 2013. p. 293.

${ }^{77}$ CARVALHOSA, Modesto. Comentários à lei de sociedades anônimas: arts. 243 a 300. $5^{\mathrm{a}}$ ed.. São Paulo: Saraiva, 2011. p. 234.

${ }^{78}$ LAMY FILHO, Alfredo; PEDREIRA, José Luiz Bulhões. A lei das S.A.: pressupostos, elaboração, aplicação. Rio de Janeiro: Renovar, 1997. v.1. p. 329.
} 
receberam, em ofertas formuladas pelo novo controlador, preços substancialmente menores do que o valor pago pelas ações de controle. ${ }^{79}$

Com a vinda da Lei $n^{o}$ 10.303/01, que promoveu alterações importantes na Lei das S.A., especialmente no que toca às proteções dos acionistas não controladores, foi inserido o art. 254-A, restaurando o direito de saída conjunta dos minoritários com o acionista controlador:

Art. 254-A. A alienação, direta ou indireta, do controle de companhia aberta somente poderá ser contratada sob a condição, suspensiva ou resolutiva, de que o adquirente se obrigue a fazer oferta pública de aquisição das ações com direito a voto de propriedade dos demais acionistas da companhia, de modo a lhes assegurar o preço no mínimo igual a $80 \%$ (oitenta por cento) do valor pago por ação com direito a voto, integrante do bloco de controle.

$\S 1$ Entende-se como alienação de controle a transferência, de forma direta ou indireta, de ações integrantes do bloco de controle, de ações vinculadas a acordos de acionistas e de valores mobiliários conversíveis em ações com direito a voto, cessão de direitos de subscrição de ações e de outros títulos ou direitos relativos a valores mobiliários conversíveis em ações que venham a resultar na alienação de controle acionário da sociedade.

§ 2o A Comissão de Valores Mobiliários autorizará a alienação de controle de que trata o caput, desde que verificado que as condições da oferta pública atendem aos requisitos legais.

§ 3o Compete à Comissão de Valores Mobiliários estabelecer normas a serem observadas na oferta pública de que trata o caput.

§ 4o O adquirente do controle acionário de companhia aberta poderá oferecer aos acionistas minoritários a opção de permanecer na companhia, mediante o pagamento de um prêmio equivalente à diferença entre o valor de mercado das ações e o valor pago por ação integrante do bloco de controle.

Atualmente, portanto, em caso de alienação de controle da companhia, é assegurado aos acionistas minoritários, nos termos do artigo 254-A, caput e $\S 4^{\circ}$, respectivamente, o direito de (i) vender suas ações ao adquirente do controle por preço no mínimo igual a $80 \%$ do valor pago pelas ações integrantes do bloco de controle e (ii) caso o adquirente do controle lhe dê a opção de permanecer, receber o pagamento de prêmio equivalente à diferença entre o valor de mercado das ações e o valor pago por ação integrante do bloco de controle.

\footnotetext{
${ }^{79}$ MUNHOZ, Eduardo Secchi. Aquisição de controle na sociedade anônima. São Paulo: Saraiva, 2013. p. 293-294.
} 


\subsubsection{Destinatários da OPA}

Da leitura do artigo 254-A, percebe-se que o legislador não deixou dúvidas de que tal oferta somente é destinada aos titulares das ações com direito a voto que não integram o bloco de controle - ou seja, as ações ordinárias (artigo 110 da Lei das S.A.), deixando de fora, via de regra, os titulares de ações preferenciais. Cabem, no entanto, algumas ponderações.

Tendo em vista que o dispositivo fala de "ação com direito a voto", poderse-ia indagar se os titulares de ações preferenciais com voto restrito - isto é, com direito de voto apenas em determinadas matérias, expressamente previstas no estatuto social ${ }^{80}$ - teriam o direito de participar da oferta pública de que trata o referido artigo.

De forma similar, nos termos do artigo $111, \S \S 1^{\circ}$ e $2^{\circ}$ da Lei das S.A., as ações preferenciais, tanto aquelas sem direito de voto quanto aquelas com voto restrito, adquirem o exercício desse direito - sem limitações - quando a companhia deixar de pagar os dividendos aos seus titulares (em prazo determinado no estatuto, porém não superior a 3 exercícios consecutivos):

Art. 111. O estatuto poderá deixar de conferir às ações preferenciais algum ou alguns dos direitos reconhecidos às ações ordinárias, inclusive o de voto, ou conferi-lo com restrições, observado o disposto no artigo 109.

$\S 1^{\circ}$ As ações preferenciais sem direito de voto adquirirão o exercício desse direito se a companhia, pelo prazo previsto no estatuto, não superior a 3 (três) exercícios consecutivos, deixar de pagar os dividendos fixos ou mínimos a que fizerem jus, direito que conservarão até o pagamento, se tais dividendos não forem cumulativos, ou até que sejam pagos os cumulativos em atraso.

$\S 2^{\circ} \mathrm{Na}$ mesma hipótese e sob a mesma condição do $\S 1^{\circ}$, as ações preferenciais com direito de voto restrito terão suspensas as limitações ao exercício desse direito.

${ }^{80}$ EIZIRIK, Nelson. Lei das S.A comentada: artigos 206 ao 300. 2a ed.. São Paulo: Quartier Latin, 2015. p. 319-320. 
Concretizando-se essa hipótese, as ações preferenciais, que possuirão pleno direito de voto, como se ordinárias fossem, até o efetivo pagamento dos dividendos pela companhia, estariam abrangidas pelo artigo 254-A?

Com efeito, a Instrução CVM no 361/02, norma regulamentadora dos procedimentos de oferta pública de ações de companhia aberta, em seu artigo 29, restringiu a oferta aos titulares de ações com "pleno e permanente direito de voto", excluindo as hipóteses acima referidas. Confira-se:

Art. 29. A OPA por alienação de controle de companhia aberta será obrigatória, na forma do art. 254-A da Lei 6.404/76, sempre que houver alienação, de forma direta ou indireta, do controle de companhia aberta, e terá por objeto todas as ações de emissão da companhia às quais seja atribuído o pleno e permanente direito de voto, por disposição legal ou estatutária.

Ainda assim, existe a possibilidade de os titulares de ações preferenciais sem direito de voto ou com restrição a esse direito venderem suas ações por ocasião da alienação privada do controle de companhia aberta ${ }^{81}$ : nos termos do $\S 1^{\circ}$ do artigo 17 da Lei das S.A., as ações preferenciais sem direito de voto ou com restrição ao exercício deste direito só serão admitidas à negociação no mercado se lhes for atribuída uma das preferências ou vantagens enunciadas nos incisos (I, II e III) do referido parágrafo. O inciso III refere-se, justamente, ao direito de inclusão na oferta pública de alienação de controle prevista no artigo 254-A da lei:

$\S 1^{\mathrm{o}}$ Independentemente do direito de receber ou não o valor de reembolso do capital com prêmio ou sem ele, as ações preferenciais sem direito de voto ou com restrição ao exercício deste direito, somente serão admitidas à negociação no mercado de valores mobiliários se a elas for atribuída pelo menos uma das seguintes preferências ou vantagens:

I - direito de participar do dividendo a ser distribuído, correspondente a, pelo menos, $25 \%$ (vinte e cinco por cento) do lucro líquido do exercício, calculado na forma do art. 202, de acordo com o seguinte critério:

\footnotetext{
${ }^{81}$ EIZIRIK, Nelson. Lei das S.A comentada: artigos 206 ao 300. $2^{\text {a }}$ ed.. São Paulo: Quartier Latin, 2015.
} p. 319-320. 
a) prioridade no recebimento dos dividendos mencionados neste inciso correspondente a, no mínimo, 3\% (três por cento) do valor do patrimônio líquido da ação; e

b) direito de participar dos lucros distribuídos em igualdade de condições com as ordinárias, depois de a estas assegurado dividendo igual ao mínimo prioritário estabelecido em conformidade com a alínea $a$; ou

II - direito ao recebimento de dividendo, por ação preferencial, pelo menos $10 \%$ (dez por cento) maior do que o atribuído a cada ação ordinária; ou

III - direito de serem incluídas na oferta pública de alienação de controle, nas condições previstas no art. 254-A, assegurado o dividendo pelo menos igual ao das ações ordinárias.

Não se trata, pois, de direito assegurado pela lei, mas pelo estatuto social da companhia, caso a mesma opte por conferir esta vantagem às suas ações preferenciais.

Também é possível o cenário de uma companhia cujo estatuto não tenha retirado nem restringido de qualquer modo o direito de voto das ações preferenciais. Nesse caso, os titulares de ações preferenciais com direito de voto também serão objeto da OPA prevista no artigo 254-A. ${ }^{82}$

Por fim, embora não haja disposição legal expressa nesse sentido, as ações objeto da OPA a posteriori devem estar livres e desembaraçadas de quaisquer ônus, gravames ou restrições que possam impedir o exercício da propriedade plena das ações por seu titular. Não incide o artigo 254-A, por exemplo, no caso de ações caucionadas, gravadas com usufruto, objeto de alienação fiduciária ou fideicomisso, vinculadas a acordos de acionistas, gravadas com cláusula de inalienabilidade, prometidas à venda, que estejam com direito de voto suspenso (artigo 120 da Lei das S.A.). Afinal, pressupõe-se que, como resultado da adesão do minoritário à oferta pública, o adquirente passará a ter a propriedade plena das ações adquiridas, podendo exercer todos os direitos a elas inerentes. A CVM vem acolhendo esse entendimento, ao registrar editais de OPA por alienação de controle contendo cláusula estabelecendo que as ações

82 PENNA, Paulo Eduardo. Alienação de controle de companhia aberta. In: COELHO, Fábio Ulhoa (Coord.). Tratado de direito comercial: relações societárias e mercado de capitais. São Paulo: Saraiva, 2015. p. 323. 
ofertadas à venda devem estar livres e desembaraçadas de quaisquer ônus ou gravames. ${ }^{83}$

\subsubsection{Hipóteses de incidência do artigo 254-A}

Conforme se depreende do próprio artigo 254-A, as exigências nele contidas não alcançam todo e qualquer tipo de alteração no controle de uma companhia. Alguns elementos são necessários para configuração da hipótese ali prevista.

A operação deve, antes de mais nada, envolver uma companhia aberta. A alienação do controle de companhia fechada, assim como de qualquer outro tipo societário, não exige a realização de OPA (salvo se avençada cláusula de tag along no estatuto social ou em contrato) ${ }^{84}$

Embora o $\S 1^{\circ}$ do dispositivo indique possíveis operações em que a oferta pública é exigível, o mesmo não pode ser considerado como uma definição legal de alienação de controle, cabendo ao aplicador da lei verificar, diante dos fatos de cada caso em espécie, se cabe ou não exigir a realização de OPA. O legislador se baseou na experiência adquirida pela CVM durante os anos 1976 a 1997, agregando no $\S 1^{\circ}$ alguns dos inúmeros casos em que se discutiu a alienação de controle e a aplicação ou não do então vigente artigo $254 .{ }^{85}$

O mesmo raciocínio se aplica ao $\S^{\circ}$ do artigo 29 da Instrução CVM n $361 / 02$ que procurou, de forma similar ao $\S 1^{\circ}$ do artigo 254-A da Lei das S.A., apontar determinadas operações - ou conjunto de operações - que exigem a realização de OPA a posteriori:

\footnotetext{
${ }^{83}$ PENNA, Paulo Eduardo. Alienação de controle de companhia aberta. In: COELHO, Fábio Ulhoa (Coord.). Tratado de direito comercial: relações societárias e mercado de capitais. São Paulo: Saraiva, 2015. p. 325-326.

${ }^{84}$ Ibid. p. 307.

${ }^{85}$ LAMY FILHO, Alfredo; PEDREIRA, José Bulhões (Coord.). Direito das Companhias. Rio de Janeiro: Forense, 2009. p. 2008-2009.
} 
§4ํ Para os efeitos desta instrução, entende-se por alienação de controle a operação, ou o conjunto de operações, de alienação de valores mobiliários com direito a voto, ou neles conversíveis, ou de cessão onerosa de direitos de subscrição desses valores mobiliários, realizada pelo acionista controlador ou por pessoas integrantes do grupo de controle, pelas quais um terceiro, ou um conjunto de terceiros representando o mesmo interesse, adquira o poder de controle da companhia, como definido no art. 116 da Lei 6.404/76.

Ambos os dispositivos deixam claro, porém, que tais operações podem envolver, além da alienação de ações com direito de voto, a alienação de outros valores mobiliários conversíveis em ações (por exemplo, debêntures conversíveis), ou a cessão de direitos de subscrição de ações ou outros títulos e direitos relativos a esses valores mobiliários conversíveis em ações. Ressalta-se que para efeitos de aplicação do artigo 254-A não basta a mera transferência, mas a conversão desses valores mobiliários em ações que conferirá ao adquirente meios para exercer o poder de controle. ${ }^{86}$

\subsubsection{Onerosidade}

A operação deve ser onerosa: o artigo 254-A da Lei das S.A. pressupõe a existência de pagamento pelas ações do bloco de controle ao exigir oferta pública de aquisição das ações votantes dos minoritários por "preço no mínimo igual a $80 \%$ (oitenta por cento) do valor pago" por ação integrante do bloco de controle. ${ }^{87} \mathrm{O}$ artigo 29 da Instrução CVM no 361/02 também dá a entender pelo caráter oneroso da operação. ${ }^{88}$ Portanto, transferências de controle decorrentes de doação ou sucessão causa mortis, por exemplo, não estão sujeitas à realização de OPA.

\footnotetext{
${ }^{86}$ PENNA, Paulo Eduardo. Alienação de controle de companhia aberta. In: COELHO, Fábio Ulhoa (Coord.). Tratado de direito comercial: relações societárias e mercado de capitais. São Paulo: Saraiva, 2015. p. 316.

${ }^{87}$ Ibid. p. 307.

${ }^{88}$ Em especial o §5o do artigo 29 da Instrução CVM no 361/02, que assim dispõe: "Sem prejuízo da definição constante do parágrafo anterior, a CVM poderá impor a realização de OPA por alienação de controle sempre que verificar ter ocorrido a alienação onerosa do controle de companhia aberta".
} 
A doutrina não é pacífica, no entanto, acerca da incidência do artigo 254A nos casos em que a alienação de controle foi onerosa, porém sem o pagamento de prêmio de controle - ou seja, o preço pago na compra das ações do bloco de controle é igual ou inferior ao valor econômico das ações (que, em companhias cujas ações têm liquidez, pressupõe-se corresponder ao valor de mercado) ${ }^{89}$

Para Luiz Leonardo Cantidiano, se a apresentação de oferta pública aos acionistas minoritários tem por objetivo exclusivo fazer com que seja estendida a eles parcela de $80 \%$ do preço que tiver sido contratado com o controlador alienante, conferindo-lhes igualdade de tratamento, não se justifica a incidência da regra quando o alienante do controle transfere as ações que integram o bloco de controle sem receber sobrepreço correspondente à mais valia decorrente da cessão das ações do bloco de controle..$^{90}$

No entanto, o entendimento da CVM, assim como de autores como Nelson Eizirik e Paulo Penna, é o da incidência do dispositivo nas alienações onerosas que se deram tanto com quanto sem pagamento do prêmio de controle:

Assim sendo, passamos à análise da aplicabilidade do art. 254-A à presente operação, em que visualizamos a existência dos elementos determinantes da oferta: a efetiva transferência do controle acionário de Elektro, a existência de público-alvo e a onerosidade da transação. Tendo em vista que o art. 254-A impõe expressamente ao adquirente do controle de companhias abertas a realização de oferta pública de aquisição das ações com direito a voto remanescentes, de modo a lhes assegurar o preço no mínimo igual a $80 \%$ do valor pago por ação integrante do bloco de controle, entendemos que a discussão da existência de deságio na alienação de Elektro em nada exime a Ashmore de cumprir a obrigação legal. ${ }^{91}$

Isto não significa, contudo, que a oferta pública somente deva ser realizada nas hipóteses em que o preço pago pela aquisição do controle contenha ágio em relação ao valor de mercado das ações emitidas pela companhia, visto que a existência de ágio não foi prevista neste artigo como pressuposto para a obrigatoriedade da OPA. [...] A realização de tal oferta pública, ainda que por valor inferior ao de cotação no mercado,

\footnotetext{
${ }^{89}$ PENNA, Paulo Eduardo. Alienação de controle de companhia aberta. In: COELHO, Fábio Ulhoa (Coord.). Tratado de direito comercial: relações societárias e mercado de capitais. São Paulo: Saraiva, 2015. p. 310.

${ }^{90}$ CANTIDIANO, Luiz Leonardo. Características das ações, cancelamento de registro e "tag along". In: LOBO, Jorge (Coord.). Reforma da Lei das Sociedades Anônimas. Rio de Janeiro: Forense, 2002, p. 93. ${ }^{91}$ CVM, Processo no 2006/7658, Reg. no 5464/07, Rel. SRE/GER-1, Rio de Janeiro, 11 abr. 2007. Disponível em <http://www.cvm.gov.br/decisoes/2007/20070411_R1.html>. Acesso em 14 mai. 2019.
} 
justifica-se na medida em que ela pode representar para os acionistas minoritários a única oportunidade de sair da companhia em conjunto com o acionista controlador, especialmente se a liquidez das ações de sua emissão no mercado secundário for reduzida. ${ }^{92}$

A nosso ver, tendo em vista que o fundamento do art. 254-A da LSA é o de conferir tratamento equitativo aos acionistas, e considerando que o requisito da onerosidade está presente, este dispositivo incide nas alienações de controle onerosas, ainda que não tenha ocorrido pagamento de prêmio de controle. Este também é o entendimento da CVM. A atribuição do deságio por um adquirente do controle pode sinalizar que há algum problema com a companhia, ainda não captado pelo mercado, causando uma queda no preço das ações em bolsa (ou mercado de balcão organizado). A OPA é a garantia de que o minoritário receberá o mesmo tratamento atribuído ao controlador alienante..$^{93}$

Ora, tem-se o cenário de uma companhia que está passando por complicações, ainda que não captadas pelo mercado, mas cujo do adquirente do controle têm ciência e, mesmo assim, se interessou na aquisição evidentemente, parte do interesse está relacionado ao preço (mais baixo) das ações do bloco de controle.

As chances da companhia se beneficiar com essa mudança no seu controle - e, portanto, na direção de seus negócios - são grandes. Se, contudo, além de adquirir as ações do bloco de controle, é imposta ao adquirente a obrigação de realizar oferta pública para aquisição das demais ações da companhia, haverá um ônus a mais para ele, possivelmente desestimulando-o a realizar o negócio.

\subsubsection{Aquisição derivada}

Prosseguindo nos requisitos de incidência do artigo 254-A, temos que o termo jurídico "alienação" significa o ato de passar para outrem o domínio de

\footnotetext{
${ }^{92}$ EIZIRIK, Nelson. Lei das S.A comentada: artigos 206 ao 300. $2^{\mathrm{a}}$ ed.. São Paulo: Quartier Latin, 2015. p. 326-327.

${ }_{93}$ PENNA, Paulo Eduardo. Alienação de controle de companhia aberta. In: COELHO, Fábio Ulhoa (Coord.). Tratado de direito comercial: relações societárias e mercado de capitais. São Paulo: Saraiva, 2015. p. 310-311.
} 
uma coisa ou a titularidade de um direito. Em vista disso, a alienação de controle se dá quando o acionista controlador transfere para um terceiro ações do bloco de controle em quantidade suficiente para que, de um lado, ocasionem a perda do poder de controle do alienante e, de outro, propiciem ao adquirente os meios para controlar a companhia. ${ }^{94}$

A propósito, a interpretação dominante do artigo 254-A da Lei das S.A., em conjunto com o artigo 29 da Instrução CVM n $361 / 02$, defende não ser necessário que o antigo controlador transfira todas as suas ações ao adquirente para caracterizar a alienação de controle, bastando que da transferência onerosa de ações resulte um novo acionista controlador: deve-se verificar que o adquirente se tornou titular de ações suficientes que lhe assegurem o controle ${ }^{95}$. Não é necessária a transferência de todas as ações do bloco de controle mas apenas de ações suficientes para acarretar o desfazimento do bloco de controle original e o surgimento de um novo bloco nas mãos do adquirente. ${ }^{96}$

Deve o adquirente, em decorrência da operação realizada, adquirir uma quantidade de ações com direito de voto que, isoladamente, ou somadas a outras ações com direito de voto da companhia das quais ele já era titular, venha a lhe assegurar uma posição de comando político da companhia. ${ }^{97}$

Trata-se, portanto, de aquisição derivada de controle acionário: ações ou direitos sobre tais ações ${ }^{98}$ que antes estavam no patrimônio do alienante são transferidas ao patrimônio do adquirente, nas mesmas condições que se encontravam nas mãos do alienante.

\footnotetext{
${ }^{94}$ PENNA, Paulo Eduardo. Alienação de controle de companhia aberta. In: COELHO, Fábio Ulhoa (Coord.). Tratado de direito comercial: relações societárias e mercado de capitais. São Paulo: Saraiva, 2015. p. 309.

${ }^{95}$ MUNHOZ, Eduardo Secchi. Aquisição de controle na sociedade anônima. São Paulo: Saraiva, 2013. p. 298.

${ }^{96}$ PENNA, Paulo Eduardo. Alienação de controle de companhia aberta. In: COELHO, Fábio Ulhoa (Coord.). Op. cit., p. 309.

${ }^{97}$ CANTIDIANO, Luiz Leonardo. Características das ações, cancelamento de registro e "tag along". In: LOBO, Jorge (Coord.). Reforma da Lei das Sociedades Anônimas. Rio de Janeiro: Forense, 2002, p. 93.

${ }^{98}$ EIZIRIK, Nelson. Temas de direito societário. Rio de Janeiro: Renovar, 2005. p. 238.
} 
A aquisição originária, por sua vez, resulta na formação, no patrimônio do novo controlador, de um bloco de controle que não existia dessa mesma forma no patrimônio de outro. ${ }^{99}$ É o caso do adquirente que compra de diversos acionistas da companhia uma quantidade suficiente de ações que lhe permitam controlar a companhia: embora tenha adquirido o controle através da compra de um número de ações suficiente para detê-lo, ninguém o possuía anteriormente, não tendo ocorrido transferência do controle de uma pessoa para outra e, por isso, não há que se falar na obrigatoriedade de oferta pública.

Significa dizer que o artigo 254-A não se aplica a companhias sem acionista controlador (isto é, com capital pulverizado); também não são abrangidas pelo dispositivo as aquisições de ações não integrantes do bloco de controle, ou seja, que não são de titularidade do acionista controlador, ainda que o resultado delas seja o aparecimento de um novo acionista controlador. ${ }^{100}$

Confira-se outros dois possíveis cenários dados por Luiz Leonardo Cantidiano $^{101}$ que não configuram alienação de controle: a companhia $\mathrm{X}$ é controlada por Y, titular de $35 \%$ de seu capital votante, estando o restante das ações ordinárias de emissão de $\mathrm{X}$ disperso em mão de vários investidores. $\mathrm{O}$ acionista Z, que detém $25 \%$ do capital votante de $\mathrm{X}$, subscreve aumento de capital da referida companhia, passando a deter $39 \%$ das ações ordinárias de sua emissão. Como o acionista Y nada subscreve no referido aumento, ele tem sua participação diluída para cerca de 22,5\% do total das ações ordinárias de emissão de $\mathrm{X}$, perdendo a posição de titular do controle que vinha exercendo.

Também pode acontecer de, no caso dessa mesma companhia $\mathrm{X}$, de que Y é controlador com 35\% do capital votante, o acionista $\mathrm{Z}$ (titular de $25 \%$ das ações ordinárias) celebrar com o acionista $\mathrm{K}$ (titular de $15 \%$ das ações

\footnotetext{
${ }^{99}$ EIZIRIK, Nelson. Temas de direito societário. Rio de Janeiro: Renovar, 2005. p. 239.

${ }^{100}$ MUNHOZ, Eduardo Secchi. Aquisição de controle na sociedade anônima. São Paulo: Saraiva, 2013, p. 299.

${ }^{101}$ CANTIDIANO, Luiz Leonardo. Características das ações, cancelamento de registro e "tag along". In: LOBO, Jorge (Coord.). Reforma da Lei das Sociedades Anônimas. Rio de Janeiro: Forense, 2002, p. 92.
} 
ordinárias) um acordo de acionistas; ou, ainda, Z e K criarem uma companhia comum, à qual aportam todas as ações ordinárias de emissão de $\mathrm{X}$ de que eram titulares. ${ }^{102}$

O Colegiado da CVM já confirmou esse entendimento algumas vezes. Veja-se, a título de exemplo, voto do Diretor Otávio Yazbek, acompanhado pelo Colegiado, no Processo CVM RJ 2009/0471:

[...] se não houver aquele controle preexistente, não há, também, que se falar em transferência, mas sim na chamada aquisição originária de controle. Em linhas gerais, a aquisição originária de controle seria aquela em que o bloco de controle tenha se constituído sem que, antes, houvesse controle definido. É o caso, por exemplo, da assunção de posição de controle por meio de aquisições realizadas de diversos alienantes, em mercado. Em tais casos, justamente por não haver um bloco de controle anteriormente constituído, não há que se falar propriamente em transferência de poder de controle, não incidindo também o regime estabelecido pelo citado art. 254-A da Lei $\mathrm{n}^{\circ} 6.404 / 76$. $^{103}$

Outro caso interessante é o Processo CVM RJ 2007/14099, envolvendo a ABN Amro Arrendamento Mercantil S.A. - companhia de capital pulverizado, sem acionista controlador definido - e a Real Leasing S.A. Arrendamento Mercantil. No caso concreto, foi realizada Oferta Pública de Aquisição de ações da $\mathrm{ABN}$, cujo sucesso foi condicionado à aceitação de acionistas que, em conjunto, detinham 50,01\% da participação acionária da companhia - o que, no entendimento da Superintendência de Registro de Valores Mobiliários (SRE), teria demonstrado negociação de preço entre os acionistas, configurando-se, portanto, a formação de um bloco de controle, o que levaria à incidência do artigo 254-A da Lei das S.A.

No entanto, seguindo o voto do Relator Durval Soledade, o Colegiado entendeu pela não exigibilidade da OPA prevista no artigo 254-A, uma vez que

${ }^{102}$ CANTIDIANO, Luiz Leonardo. Características das ações, cancelamento de registro e "tag along". In: LOBO, Jorge (Coord.). Reforma da Lei das Sociedades Anônimas. Rio de Janeiro: Forense, 2002, p. 93.

${ }^{103}$ CVM, Processo ${ }^{\circ}$ 2009/0471, Reg. ${ }^{\circ}$ 6357/09, Rel. Diretor Otavio Yazbek, Rio de Janeiro, 3 mar. 2009. Disponível em <http://www.cvm.gov.br/decisoes/2009/20090303_R1/20090303_D07.html>. Acesso em 14 mai. 2019. 
a negociação entre os acionistas não seria suficiente para caracterizar a operação como uma alienação de controle, tratando-se de aquisição originária de controle:

43 Logo, com a oferta pública de aquisição de ações realizada pela RFS, operou-se a formação da posição de acionista controlador no ABN, até então inexistente. Assim, a aquisição do controle no caso concreto caracterizou-se como originária, visto que não ocorreu efetivamente a transferência de bloco de controle, tal como acontece na alienação de controle, mas sim o seu surgimento. 44 A doutrina é pacífica quanto à conceituação e a utilização dos conceitos de aquisição de controle derivada e originária, caracterizando-se a última quando da operação resultar a formação de bloco de controle no patrimônio de um acionista ou grupo, até então inexistente na companhia; e está regulada no art.257 da LSA. Ao contrário, caracteriza-se como aquisição derivada aquela em que um acionista ou um grupo de acionistas controladores transferem o bloco de ações ou os direitos que lhes garantiam o poder de controle a outro acionista ou terceiro, tornando-se estes os novos controladores. 45 A modalidade de aquisição originária, a meu ver, não se enquadra nos requisitos elencados no art. 254-A, mais precisamente a necessidade de ter havido transferência onerosa do controle (alienação), considero afastada a necessidade de realização de OPA no caso concreto. ${ }^{104}$

\subsubsection{Alienação indireta}

A alienação de controle também pode se dar indiretamente. Significa dizer que a alienação de controle indireto, fenômeno já descrito no item 1.2., se sujeita à realização da OPA prevista no artigo 254-A da Lei das S.A.: o dispositivo é expresso nesse sentido. O caput do artigo 29 da Instrução CVM n ${ }^{\circ}$ 361/02 também fala expressamente de obrigatoriedade de OPA por alienação de controle "sempre que houver alienação, de forma direta ou indireta".

A transferência do controle indireto é o efeito da transferência do controle direto da sociedade de comando do grupo ou de uma sociedade interposta ${ }^{105}$ :

\footnotetext{
${ }^{104}$ CVM, Processo no 2007/14099, Reg. Col. no 5801/2008, Rel. Diretor Durval Soledade, Rio de Janeiro, 29 jan. 2008. Disponível em <http://www.cvm.gov.br/decisoes/2008/20080129_R1.html>. Acesso em 13 mai. 2019.

${ }^{105}$ LAMY FILHO, Alfredo; PEDREIRA, José Bulhões (Coord.). Direito das Companhias. Rio de Janeiro: Forense, 2009. p. 2017.
} 
Por exemplo, quando a sociedade holding $(A)$ controla outra sociedade $(B)$ que, por sua vez, controla uma terceira companhia $(C)$, a alienação do controle direto de $A$ acarreta a alienação do controle indireto de $B$ e $C .{ }^{106}$

Ressalta-se, contudo, que o significado de alienação indireta de controle não se restringe à venda de controle indireto. Em muitas situações, tem-se, em essência, uma transferência (onerosa) do controle, ainda que a propriedade dos das ações do bloco de controle não tenha sido transferida.

É o caso, por exemplo, do acionista controlador instituir (onerosamente) a um terceiro o usufruto sobre as ações do bloco de controle, este terceiro poderá, utilizando-se das as ações com direito de voto da qual é usufrutuário, exercer o poder de controle da companhia. ${ }^{107}$ Nesse sentido, confira-se voto do Diretor Pedro Oliva Marcilio de Sousa, acompanhado pelo Colegiado, no Processo CVM RJ2005/4069 (caso CDB/Pão de Açúcar):

\begin{abstract}
36. Boa parte da objetividade do critério proposto nos parágrafos acima se perde em razão da utilização da expressão "alienação direta e indireta", no caput e no $\S 1^{\circ}$ do art. 254-A. Isso porque, o significado tradicional dessa expressão - dá-se alienação de controle mesmo que se interponha uma sociedade holding para a realização da alienação das ações da companhia aberta - que vinha sendo aplicado pela CVM ainda quando o antigo art. 254, que não falava em alienação indireta, e amplamente aceito pela doutrina, não é o único sentido da expressão. Há um outro significado cuja aplicação só pode ser analisada a partir dos fatos do caso concreto. 37. Esse significado inclui, dentre as operações que dão causa à oferta pública, não só a alienação de ações agrupadas em sociedade holding, mas, também, a inclusão de acertos contratuais que impliquem a transferência dos direitos políticos e econômicos do valor mobiliário, sem a transferência da ação (a conferência de usufruto vitalício de voto e dividendos mediante contraprestação em dinheiro ou a celebração de acordo de acionistas, regulando voto e distribuição de dividendos, por exemplo), tenha esse acordo sido celebrado para se evitar a realizar a oferta pública ou mesmo com vistas a um outro fim lícito. Como isso, para a aplicação do art. 254-A, se em uma operação não se verificar a transferência de valores mobiliários que implique alienação de controle, deve-se analisar se essa alienação ocorreu de forma indireta (i.e., mediante acordos que resultem na transferência de poder político e econômico desses valores mobiliários). ${ }^{108}$
\end{abstract}

\footnotetext{
${ }^{106}$ PENNA, Paulo Eduardo. Alienação de Controle de Companhia Aberta. São Paulo: Quartier Latin, 2012. p. 126.

${ }^{107}$ Ibid. p. 138.

${ }^{108}$ CVM, Processo ${ }^{\circ}$ 2005/4069, Reg. $n^{\circ}$ 4788/05, Rel. Pedro Oliva Marcilio de Sousa, Rio de Janeiro, 11 abr. 2006. Disponível em <http://www.cvm.gov.br/decisoes/2006/20060411_R1.html>. Acesso em 14 mai. 2019.
} 
Ou seja, ainda que não haja a transferência propriamente dita de valores mobiliários, se os direitos políticos e econômicos por eles conferidos forem transferidos, a referida operação pode ensejar a aplicação do artigo 254-A da Lei das S.A.

\subsubsection{Alienação em etapas}

Embora já se pudesse extrair do $\S 1^{\circ}$ do artigo 254-A da Lei das S.A. interpretação nesse sentido - uma vez que o mesmo lista um elenco exemplificativo de operações que podem ensejar a alienação de controle acionário e, muitas vezes, se desenvolvem ao longo do tempo ${ }^{109}$ - a Instrução CVM n $n^{\circ} 361 / 02$ não deixou dúvidas, em seu artigo 29 , $\$ 4^{\circ}$, sobre a obrigatoriedade de OPA a posteriori nos casos de alienação do controle em etapas - isto é, a transferência (onerosa) do controle pode derivar de uma única operação ou de um conjunto de operações.

A cessão onerosa de direitos de subscrição de ações, por exemplo, exige no mínimo dois atos: a venda do direito de subscrição e a posterior subscrição das ações votantes. ${ }^{110}$ Outro exemplo é o caso de um terceiro adquirir do acionista controlador de uma companhia, titular de $51 \%$ das ações votantes, um percentual baixo de ações; pouco tempo depois, adquire também do controlador debêntures conversíveis em ações e, passado um tempo, converte-as; em seguida, compra mais algumas ações do controlador - que, a essa altura, já terá sua participação diluída, passando o terceiro a deter participação acionária que lhe garanta a preponderância nas deliberações sociais.

Sobre o tema, é interessante analisar o Processo CVM RJ2015/8340, que discutiu o preço a ser praticado em OPA por alienação da totalidade do bloco de

\footnotetext{
${ }^{109}$ EIZIRIK, Nelson. Temas de direito societário. Rio de Janeiro: Renovar, 2005. p. 242.

${ }^{110}$ PENNA, Paulo Eduardo. Alienação de Controle de Companhia Aberta. São Paulo: Quartier Latin, 2012. p. 141.
} 
controle da Somos Educação S.A., ocorrida em 3 etapas. Para a adquirente do controle, Thunnus Participações S.A., a primeira aquisição (de 19,9\% da participação acionária) não deveria ser considerada, pois não havia, à época, intenção de adquirir o controle. A CVM, além de não ter questionado, em momento algum, a incidência do artigo 254-A da Lei das S.A. nos casos de alienação do controle em etapas, entendeu não ser relevante a intenção ou o (des)interesse na aquisição do controle da Companhia, considerando as 3 etapas como o conjunto de operações que resultou na alienação de controle:

70. Pois, como se observa, sem aquisição de ações realizada na primeira etapa (em 07/08/2014), o percentual de ações adquirido na segunda etapa (em 02/04/2015), data em que se efetivou a alienação de controle, não faria da Ofertante a nova controladora da Companhia. [...] 76. De volta ao debate sobre a Ofertante ter tido ou não a intenção de adquirir o controle da Companhia, quando da primeira aquisição de ações realizada em 07/08/2014, ressaltamos não haver menção a essa particularidade (a intenção) em qualquer dispositivo legal ou normativo sobre o tema, como requisito a ser considerado na formação de preço de uma OPA por alienação de controle. 77. Ou seja, não é a intenção (ou sua ausência) por parte da Ofertante que caracteriza a alienação de controle da Companhia como tendo ocorrido em etapas, mas o conjunto de operações em si. 78. Caso a intenção ou não de o novo controlador adquirir o controle de uma companhia aberta fosse um elemento a ser considerado nas transações de compras de ações feitas com o antigo controlador, estaríamos diante de uma situação completamente subjetiva. ${ }^{111}$

A alienação de controle em etapas pressupõe a realização de atos que, individualmente considerados, não caracterizam alienação de controle. A alienação de controle é revelada apenas quando tais atos são examinados em seu conjunto. ${ }^{112}$

\footnotetext{
${ }^{111}$ CVM, Processo no 2015/8340, Reg. no 9867/15, Rel. SRE/GRE-1, Rio de Janeiro, 29 set. 2015. Disponível em <http://www.cvm.gov.br/decisoes/2015/20150929_R1.html>. Acesso em 14 mai. 2019. 112 PENNA, Paulo Eduardo. Alienação de Controle de Companhia Aberta. São Paulo: Quartier Latin, 2012. p. 141.
} 


\subsubsection{Controle não efetivo e controle potencial}

De acordo com o já exposto no Capítulo 1, a Lei das S.A., em seu artigo 116, define o acionista controlador como aquele que detém número suficiente de ações que lhe permita, de maneira estável e permanente, fazer prevalecer a sua vontade nas assembleias gerais e eleger a maioria dos administradores da companhia. Mas não basta ser titular desse número de ações: exige-se o uso efetivo, nas assembleias gerais, dessa preponderância que suas ações lhe conferem.

Por isso, há quem entenda, como Roberta Nioac ${ }^{113}$, que para efeito de incidência do artigo 254-A da Lei das S.A., a alienação de controle deve consubstanciar um poder de controle que até então era efetivamente exercido pelo acionista alienante, não bastando consubstanciar uma quantidade suficiente de ações que permitam ao adquirente comandar agora os negócios da companhia.

Por outro lado, parece prevalecer o entendimento de que não descaracteriza o negócio de alienação de controle o fato de o alienante não estar exercendo efetivamente o poder de controle, ou do adquirente, após a celebração do negócio, decidir não exercer o direito de voto que lhe é conferido pelas ações do bloco de controle adquiridas. ${ }^{114}$

Houve a transferência do controle, isto é, a transferência dos valores mobiliários e/ou direitos que asseguram o poder de preponderar nas deliberações societárias. Ainda que o alienante não exercesse esse poder, ou o adquirente decida não exercê-lo, a operação concederá ao adquirente a possibilidade de

\footnotetext{
113 PRADO, Roberta Nioac. Oferta Pública de ações obrigatórias nas S.A..São Paulo: Quartier Latin, 2005, p. 126-128.

114 Nesse sentido, cf. PENNA, Paulo Eduardo. Alienação de controle de companhia aberta. In: COELHO, Fábio Ulhoa (Coord.). Tratado de direito comercial: relações societárias e mercado de capitais. São Paulo: Saraiva, 2015. p. 310; PARENTE, Norma. Mercado de Capitais. In: CARVALHOSA, Modesto (Coord.). Tratado de Direito Empresarial. São Paulo: Revista dos Tribunais, 2016. v. 6. p. 447-448.
} 
assumir o comando efetivo dos negócios no momento que desejar, sendo, portanto, devida a oferta pública aos minoritários no momento em que for concretizada a alienação. ${ }^{115}$ É de se esperar, inclusive, que nesse tipo de operação haja o pagamento de prêmio de controle, já que ao adquirente será conferida a possibilidade de exercer o controle da companhia se ele quiser. ${ }^{116}$

Foi nesse sentido que o Colegiado da CVM se pronunciou caso CDB/Pão de Açúcar. Confira-se:

[...] Se o alienante é titular de mais da metade das ações com direito a voto da companhia aberta, mas não exerce seu direito de voto, ele não é considerado, para fins do art. 116, como acionista controlador. Nada obstante, caso ele aliene essas ações e o terceiro adquirente tenha interesse em exercer o controle da companhia, esse adquirente estará apto a exercê-lo e deveria estar disposto a pagar o mesmo prêmio de controle que pagaria a um acionista controlador propriamente dito, dado que o bloco de ações de um (acionista controlador) ou de outro (acionistas com ações suficientes para ser considerado acionista controlador, mas que não exerce o controle) concederá ao adquirente os mesmos direitos. $\mathrm{O}$ fato de o alienante não ser considerado acionista controlador, para fins do art. 116, "b", justificaria a não realização de oferta pública nesse caso? Creio que não. ${ }^{117}$

No que diz respeito à compra e venda de "ações em potência" (tais como debêntures conversíveis em ações, bônus de subscrição, direito de preferência para subscrição de ações), a alienação de controle só se consumará com a conversão ou subscrição. ${ }^{118}$

Tendo uma pessoa adquirido (não por emissão da própria companhia, caso em que estar-se-ia diante de uma aquisição originária), por exemplo,

115 SIQUEIRA, Carlos Augusto Junqueira de. Transferência do Controle Acionário: Interpretação e Valor. Niterói: FMF, 2004. p. 69.

${ }^{116}$ PENNA, Paulo Eduardo. Alienação de controle de companhia aberta. In: COELHO, Fábio Ulhoa (Coord.). Tratado de direito comercial: relações societárias e mercado de capitais. São Paulo: Saraiva, 2015. p. 310.

${ }^{117}$ CVM, Processo n ${ }^{\circ}$ 2005/4069, Reg. no 4788/05, Rel. Pedro Oliva Marcilio de Sousa, Rio de Janeiro, 11 abr. 2006. Disponível em <http://www.cvm.gov.br/decisoes/2006/20060411_R1.html>. Acesso em 14 mai. 2019.

${ }^{118}$ LAMY FILHO, Alfredo; PEDREIRA, José Bulhões (Coord.). Direito das Companhias. Rio de Janeiro: Forense, 2009. p. 2012. Nesse sentido, cf. CVM, Processo n ${ }^{\circ}$ 2005/4069, Reg. nº 4788/05, Rel. Pedro Oliva Marcilio de Sousa, Rio de Janeiro, 11 abr. 2006. Disponível em <http://www.cvm.gov.br/decisoes/2006/20060411_R1.html>. Acesso em 14 mai. 2019. 
debêntures conversíveis em ações em quantidade suficiente a, em caso de convertê-las, passar a deter ações ordinárias em quantidade superior àquela possuída pelo até então acionista controlador: a conversão não é um fato sobre o qual se tem certeza. A transferência do controle só será efetivada se e quando esses títulos forem convertidos - momento em que, aí sim, incidirá a obrigação de efetuar a oferta pública determinada pelo artigo 254-A. ${ }^{119}$

\subsubsection{Controle compartilhado}

Cabe relembrar que existe também o controle compartilhado, reconhecido pelo artigo 116 da Lei das S.A., ocasião em que o poder de controle é exercido por um grupo de pessoas, físicas ou jurídicas, unidos por acordo de votos (ou submetidos a controle comum), sendo o bloco de controle formado pelas ações de titularidades de cada um dos acionistas que integram o grupo controlador. O poder de controle, nesse caso, não é atributo de cada um dos acionistas, individualmente considerados, mas do grupo. ${ }^{120}$

A venda coletiva, pelos acionistas do grupo controlador, da totalidade das ações do bloco de controle atrai, evidentemente, a regra do artigo 254-A. ${ }^{121}$ Em compensação, na hipótese de apenas parte das ações do grupo serem vendidas, cabem algumas ponderações.

Há quem entenda que o ingresso de um terceiro, que antes não fazia parte do grupo de controle, tem como resultado o surgimento de um novo acionista controlador e, por isso, incide automaticamente o artigo 254-A, pouco importando a sua posição (se subordinada ou dominante) no grupo. ${ }^{122}$

\footnotetext{
${ }^{119}$ SIQUEIRA, Carlos Augusto Junqueira de. Transferência do Controle Acionário: Interpretação e Valor. Niterói: FMF, 2004. p. 67-68.

${ }^{120}$ PENNA, Paulo Eduardo. Alienação de controle de companhia aberta. In: COELHO, Fábio Ulhoa (Coord.). Tratado de direito comercial: relações societárias e mercado de capitais. São Paulo: Saraiva, 2015. p. 313.

${ }^{121}$ Ibid. p. 313-314.

${ }^{122}$ MUNHOZ, Eduardo Secchi. Aquisição de controle na sociedade anônima. São Paulo: Saraiva, 2013, p. 300 .
} 
Por outro lado, também existe o entendimento de que a aquisição, por um terceiro, estranho ao grupo controlador (seja ele acionista da companhia ou não) de ações do bloco de controle e o seu ingresso no grupo controlador em posição minoritária ou subordinada não caracteriza a alienação de controle para fins do artigo 254-A. Por outro lado, ainda que tendo adquirido um número de ações insuficientes para exercer isoladamente o controle, se este terceiro, em decorrência do arranjo de forças sacramentado no acordo de acionistas, assumir posição dominante no grupo, conseguindo impor sua decisão aos demais integrantes do grupo controlador, configura-se a alienação de controle. ${ }^{123}$

Exige-se, portanto, uma análise casuística para verificar a existência ou não de predominância no grupo controlador e, consequentemente, a configuração ou não da alienação de controle aqui referida. ${ }^{124}$

Seguindo essa linha de raciocínio, também não caracteriza alienação de controle a venda de ações preferenciais, sem direito a voto, que estejam vinculadas a acordos de acionistas celebrados com o titular do controle acionário. ${ }^{125}$

No caso da transferência de ações se dar entre acionistas pertencentes ao grupo de controle, ou seja, de um ou mais acionistas do grupo venderem suas ações a outro acionista do grupo, não haverá a entrada de um terceiro, de um novo acionista no bloco de controle. Por isso, há quem sustente que neste tipo de situação não incide o artigo 254-A. ${ }^{126}$

\footnotetext{
${ }^{123}$ PENNA, Paulo Eduardo. Alienação de controle de companhia aberta. In: COELHO, Fábio Ulhoa (Coord.). Tratado de direito comercial: relações societárias e mercado de capitais. São Paulo: Saraiva, 2015. p. 314.

${ }^{124}$ Ibid. p. 314.

${ }^{125}$ CANTIDIANO, Luiz Leonardo. Características das ações, cancelamento de registro e "tag along". In: LOBO, Jorge (Coord.). Reforma da Lei das Sociedades Anônimas. Rio de Janeiro: Forense, 2002, p. 94.

126 "A simples mudança de posição dentro do bloco de controle, com a transferência de ações de um acionista para outro, sem que haja alteração da vontade prevalecente dentro do grupo controlador, não configure alienação de controle, pois tal transferência de ações dá ensejo a uma mera consolidação do controle." (EIZIRIK, Nelson. Lei das S.A comentada: artigos 206 ao 300. $2^{\mathrm{a}}$ ed.. São Paulo: Quartier Latin, 2015. p. 324.).
} 
Para outros, incide a regra do dispositivo se, na transferência das ações, o acionista alienante (ou acionistas alienantes) ceder para o adquirente a posição de preponderância que antes detinha no grupo. ${ }^{127}$ Caberia diferenciar a situação em que há efetiva modificação do centro de gravidade do poder, que passa do acionista alienante ao acionista adquirente, da situação em que não há o aparecimento de uma nova vontade dominante, (i) seja porque as novas ações adquiridas pelo adquirente, em conjunto com as que ele já detinha, não são suficientes para atingir posição preponderante no grupo, (ii) seja porque o adquirente já detinha posição de preponderância no grupo, tratando-se apenas a consolidação ou reforço do poder já detido. ${ }^{128}$

Sobre essa questão, o Colegiado da CVM apreciou, no Processo Administrativo CVM RJ 2001/10329, caso envolvendo a alienação de ações detidas pela Mondi Brazil Ltda. e Mondi International S.A. ("Grupo Mondi”), de emissão da Aracruz Celulose S.A. (“Aracruz"), à Votorantim Celulose e Papel S.A. O Grupo Mondi era titular de $28 \%$ do capital social da Aracruz e fazia parte de Acordo de Acionistas, em conjunto com outras três empresas uma delas com participação de $12,5 \%$ e as outras duas com participações, cada uma, de $28 \%$.

O Relator Marcelo Trindade, acompanhado do Colegiado da CVM, se manifestou no sentido de que aludida operação não ensejaria a necessidade de OPA por alienação de controle, nos seguintes termos:

Ocorre que este caso não desafia as complexas questões que podem surgir quanto ao conceito de alienação de controle detido por grupo de acionistas unidos por acordo. Aqui não houve alienação de uma participação majoritária dentro do bloco de controle, como se viu do quadro transcrito no relatório, nem se está diante da aquisição de uma

\footnotetext{
127 PENNA, Paulo Eduardo. Alienação de controle de companhia aberta. In: COELHO, Fábio Ulhoa (Coord.). Tratado de direito comercial: relações societárias e mercado de capitais. São Paulo: Saraiva, 2015. p. 314-315.

${ }^{128}$ MUNHOZ, Eduardo Secchi. Aquisição de controle na sociedade anônima. São Paulo: Saraiva, 2013, p. 300 .
} 
participação que, somada àquela já detida pelo adquirente, o eleve à condição de controlador único. ${ }^{129}$

\title{
No Processo CVM RJ2007/7230 (caso Copesul), analisou-se a
}

necessidade de OPA no caso de alienação de ações entre dois acionistas que controlavam em conjunto, por meio de Acordo de Acionistas, a Companhia. Entendeu-se, nos termos do voto do Diretor Relator Eli Loria, que foi acompanhado pelo Colegiado, não ser necessária a realização de OPA:

\begin{abstract}
Destarte, para que ocorra a alienação do controle, necessário que haja mudança na titularidade do poder de controle, sendo fundamental, portanto, a presença de novo controlador. Tal questão ganha ainda mais perspectiva se verificarmos que o próprio fundamento da OPA, a sua razão de ser, está no resguardo do direito dos acionistas não controladores de se retirarem de uma companhia que, uma vez controlada por pessoa diversa da que o fazia antes, já não representa seus interesses. No caso em comento, as empresas signatárias de Acordo de Acionistas, BRASKEM e IPQ, detinham participações paritárias e o controle da COPESUL era exercido pela comunhão de vontades das duas sociedades. Assim, como nenhuma das duas empresas exercia isoladamente o controle da COPESUL, tem-se que a IPQ alienou valores mobiliários para a BRASKEM, mas não o poder de controle, pois não detinha o mesmo, pelo menos não em sua plenitude. ${ }^{130}$
\end{abstract}

\section{O Presidente Marcelo Trindade apresentou declaração de voto com} considerações adicionais, ressalvando:

25. Concluir pela não obrigatoriedade de OPA em casos de consolidação do controle dentro do bloco não é, certamente, adotar a decisão mais simpática. E certamente este não é o voto que eu mais gostaria de dar. De lege ferenda, me parece que a alienação de participações relevantes, conforme percentual previsto em lei ou no Estatuto, deveria gerar a obrigação de estender as mesmas condições aos demais acionistas, através da realização de OPA. Isto contribui para que o valor das ações de uma companhia aberta seja estabelecido pelo mercado de maneira mais adequada, sem prêmios ou descontos economicamente pouco justificáveis, decorrentes de direitos não expressos nos títulos, mas sim inerentes ao exercício do poder. 26. Mas o fato é que, de lege lata, estou de acordo com a conclusão do voto do Diretor Relator, pela inexistência de alienação de controle, que só pode ser alienado por quem o detenha, o que, em casos de acordo de acionistas, significa o grupo de pessoas vinculadas por

${ }^{129}$ CVM, Processo no 2001/10329, Reg. $n^{\circ}$ 3528/02, Rel. Diretor Marcelo Trindade, Rio de Janeiro, 19 fev. 2002. Disponível em <http://www.cvm.gov.br/decisoes/2002/20020219_R1.html>. Acesso em 13 mai. 2019.

${ }^{130}$ CVM, Processo no 2007/7230, Reg. $n^{\circ}$ 5533/07, Rel. Eli Loria, 11 jul. 2007. Disponível em <http://www.cvm.gov.br/decisoes/2007/20070711_R2.html>. Acesso em 15 mai. 2019. 
acordo de voto , como diz o art. 116 da Lei das S.A., e não um membro desse grupo que detenha menos que a maioria das ações com voto, ressalvada a análise do acordo de acionistas, que revele a preponderância do subscritor alienante perante os demais. ${ }^{131}$

\subsubsection{Controle minoritário}

Tendo em vista que o artigo 116 da Lei das S.A. não exige um número determinado de ações com direito a voto para caracterizar o acionista controlador, ele se aplica não apenas aos controles totalitário e majoritário, mas também ao minoritário. Mas a alienação de controle de que fala o artigo 254-A também englobaria o controle minoritário?

Paira certa controvérsia sobre o tema. Durante a vigência do artigo 254, essa questão era expressamente tratada na Resolução 401/76, que refletia a incidência do dispositivo nos casos de alienação de controle minoritário, exigindo, como critério de permanência para caracterização do controle minoritário, a maioria dos votos nas três últimas assembleias. Por sua vez, a Instrução $\mathrm{n}^{\mathrm{o}}$ 361/02, norma regulamentadora dos procedimentos de oferta pública de ações de companhia (em observância aos $\S \S 2^{\circ}$ e $3^{\circ}$ do artigo 254-A da Lei das S.A.) não é expressa sobre o assunto. ${ }^{132}$

Para alguns ${ }^{133}$, uma vez que a Lei das S.A. reconhece o controle minoritário, considerando controlador aquele que elege a maioria dos administradores e não exige o atingimento de um percentual de ações com direito de voto como indicativo de controle, e o artigo 254-A não elege um critério absoluto, é exigível OPA em caso de alienação de controle minoritário.

\footnotetext{
${ }^{131}$ CVM, Processo n ${ }^{\circ}$ 2007/7230, Reg. nº 5533/07, Rel. Eli Loria, Declaração de Voto do Presidente, 11 jul. 2007. Disponível em <http://www.cvm.gov.br/decisoes/2007/20070711_R2.html>. Acesso em 15 mai. 2019.

132 PENNA, Paulo Eduardo. Alienação de controle de companhia aberta. In: COELHO, Fábio Ulhoa (Coord.). Tratado de direito comercial: relações societárias e mercado de capitais. São Paulo: Saraiva, 2015. p. 311-312.

133 PARENTE, Norma. Mercado de Capitais. In: CARVALHOSA, Modesto (Coord.). Tratado de Direito Empresarial. São Paulo: Revista dos Tribunais, 2016. v. 6. p. 449; PENNA, Paulo Eduardo. Alienação de controle de companhia aberta. In: COELHO, Fábio Ulhoa (Coord.). Op. cit., p. 312.
} 
Paulo Penna ressalva que o exercício desse controle minoritário deve se dar de modo permanente, sem que haja alguma circunstância que configure uma ameaça a essa estabilidade - podendo a preponderância nas três últimas assembleias ser, inclusive, um primeiro critério a comprovar a permanência, devendo ser confrontada com outros elementos fáticos. E, não sendo possível identificar de modo conclusivo a existência desse controle minoritário, deve-se afastar a incidência do artigo 254-A. Até mesmo porque "na eventual compra das ações desse bloco de controle minoritário instável dificilmente haverá o pagamento de um elevado sobrevalor pelas ações". ${ }^{134}$

A CVM teve a oportunidade de apreciar o tema no Processo CVM RJ2009/1956 ${ }^{135}$, que envolvia a transferência do controle de fato da Telecom Italia e, por consequência, do controle indireto da TIM Participações. O Colegiado, por maioria (ressalvado o Diretor Eli Loria ${ }^{136}$ ), entendeu ser possível a aplicação do artigo 254-A nos casos de controle minoritário, devendo a questão ser analisada caso a caso, conforme as peculiaridades da negociação, e conferindo ao critério da permanência caráter de extrema relevância, senão indispensável.

Em compensação, também se entendeu por maioria que, naquele caso concreto, a OPA por alienação não seria exigível: a Presidente Maria Helena Santana concluiu que a legislação aplicável seria a italiana, que não exigiria a realização de OPA nesse caso; o Diretor Otavio Yazbek entendeu não ter restado configurado o controle de fato; e o Diretor Eli Loria se manifestou pela

\footnotetext{
${ }^{134}$ PENNA, Paulo Eduardo. Alienação de controle de companhia aberta. In: COELHO, Fábio Ulhoa (Coord.). Tratado de direito comercial: relações societárias e mercado de capitais. São Paulo: Saraiva, 2015. p. 312-313.

${ }^{135}$ CVM, Processo n ${ }^{\circ}$ 2009/1956, Reg. Col. no 6360/09, Rel. Diretor Eliseu Martins, Rio de Janeiro, 15 jul. 2009. Disponível em <http://www.cvm.gov.br/decisoes/2009/20090715_R2.html>. Acesso em 13 mai. 2019.

136 “ “....] se o alienante não possui o poder de controle de forma permanente, ainda que seja o 'controlador de fato', não pode alienar o que não tem e o adquirente não se obriga a realizar oferta pública de aquisição perante os demais acionistas" (CVM, Processo n 2009/1956, Reg. Col. nº 6360/09, Rel. Diretor Eliseu Martins, Voto do Diretor Eli Loria, Rio de Janeiro, 15 jul. 2009. Disponível em <http://www.cvm.gov.br/decisoes/2009/20090715_R2.html>. Acesso em 13 mai. 2019).
} 
exigibilidade da OPA prevista no artigo 254-A da Lei das S.A. apenas nos casos de alienação de bloco superior a 50\%. Restou vencido o Diretor Relator Eliseu Martins, cujo voto foi acompanhado pelo Diretor Marcos Pinto, que havia entendido ter restado configurada a alienação de controle minoritário de modo indireto. Confira-se:

A lei, se quisesse se referir apenas ao controle majoritário, poderia tê-lo feito expressamente ou mesmo se referido à "maioria absoluta" do capital votante da companhia, e não à "maioria dos votos nas deliberações da assembleia-geral". [...] "de modo permanente" significa que a preponderância nas deliberações sociais depende apenas da vontade do suposto controlador, e não de acontecimentos casuais, imprevistos, que independam da ação do suposto controlador. 7. É claro que essa preponderância, no extremo, apenas é garantida nos casos de controle majoritário, pois nesses casos há impossibilidade fática de o controlador encontrar resistência à sua vontade nas assembleias. Mas essa visão extrema não me parece a melhor interpretação do art. 116 e visivelmente esse também não é o entendimento do Prof. Comparato, já que ele admite que o art. 116 engloba o controle minoritário. 8. Nos casos de alta dispersão acionária e forte absenteísmo, existe uma justa expectativa de que um acionista que tenha menos de $50 \%$ mais uma das ações representativas do capital votante da companhia consiga fazer valer sua vontade nas assembleias gerais. Nesse sentido, dadas as circunstâncias do caso concreto e analisando-se o histórico das assembleias da companhia, há forte probabilidade de que o acionista faça valer sua vontade. ${ }^{137}$

3.5 A discussão sobre permanência da situação de controle e que critérios seriam capazes de a caracterizar, embora tenha sido muito bem feita pelo Diretor Eliseu Martins em seu voto, e eu concorde com suas conclusões naquele aspecto, é muito sujeita às visões dos que decidirão cada caso e não seria, em minha visão, positiva para o ambiente de negócios no Brasil. O conceito de controle de fato, sujeito em cada caso ao grau de dispersão do capital da sociedade e ao absenteísmo dos demais acionistas, é bastante útil para a apuração de responsabilidades em episódios específicos, mas pode trazer insegurança se for utilizado para avaliar a incidência ou não da obrigação de realização de OPA por alienação de controle. $3.6 \mathrm{Em}$ suma, entendo que se hoje existem companhias no Brasil em que não há dúvida de que o controle é exercido por determinados acionistas minoritários - seja porque detêm participações extremamente relevantes e têm prevalecido em assembleias ao longo do tempo, por estarem vinculados por acordos de voto ou pela participação mais evidente na própria gestão da companhia -, há outras situações em que essa caracterização seria muito difícil de obter tão claramente, e em que seria de extrema valia a existência de critérios conhecidos e públicos para essa análise. 3.7 Entendo, por isso, que é fundamental o esforço de construção de critérios que permitam tornar mais previsível e segura a avaliação a ser feita nos casos concretos. E para que se possa evitar a excessiva

\footnotetext{
${ }^{137}$ CVM, Processo n ${ }^{\circ}$ 2009/1956, Reg. Col. $n^{\circ}$ 6360/09, Rel. Diretor Eliseu Martins, Voto do Relator, Rio de Janeiro, 15 jul. 2009. Disponível em <http://www.cvm.gov.br/decisoes/2009/20090715_R2.html>. Acesso em 13 mai. 2019.
} 
subjetividade de análises puramente casuísticas, sou de opinião que o mais conveniente seria a adoção do percentual de $30 \%$ do capital votante, presumindo-o como representativo do controle minoritário de sociedades em que não haja outro acionista detentor de um bloco de ações maior que esse. Mas a discussão sobre qual seria a melhor baliza ainda deve ser muito aprofundada, bem como a avaliação sobre que mecanismos haveria, à disposição da CVM, para adotar essas definições. ${ }^{138}$

Não gostaria aqui de, no mesmo diapasão da declaração de voto apresentada pelo Diretor Eli Loria no presente caso, afastar de pronto qualquer possibilidade de negócio jurídico que transfira poder de controle minoritário e que, com isso, possa vir a ensejar a aplicação do art. 254-A da lei acionária. A bem da verdade, creio que tal possibilidade não é de todo inconsistente com o regime do citado art. 254-A, mesmo porque, ainda na vigência do art. 254 original (que, revogado pela Lei n. 9.457/97, foi o embrião do atual art. 254-A, incluído pela Lei n. 10.303/01), a Resolução CMN n. 401/76, que regulamentava aquele dispositivo, já tratava expressamente do controle minoritário. (...) ela sinaliza que, muito provavelmente, a possibilidade de alienação de controle minoritário para os fins do art. 254-A não é descabida. A análise deve realizar-se caso a caso - nesta linha, aliás, é extremamente sintomático que o regime anteriormente vigente tenha remetido a determinados fatos bastante concretos ("as três últimas Assembléias Gerais da companhia"), de modo a afastar, do controle minoritário, justamente aquela fugacidade, aquela instabilidade, que usualmente o caracteriza. É claro que, sem balizadores objetivos (e em certa medida arbitrários) como aqueles, torna-se muito mais difícil identificar o controle minoritário e, ao mesmo tempo, outorgar aos agentes de mercado a segurança necessária. Ainda assim, parece-me importante não negar a priori tal possibilidade. ${ }^{139}$

Por outro lado, há quem entenda, como Nelson Eizirik ${ }^{140}$, não ser obrigatória a realização de OPA por alienação de controle minoritário, não devendo o artigo 116 da Lei das S.A.- que admite o controle minoritário - servir de base para a interpretação dos casos de alienação de controle.

A transferência de controle disciplinada no artigo 254-A não estaria subordinada integralmente à definição de acionista controlador prevista na lei, que tem abrangência mais ampla, destinando-se a outras finalidades, em especial

\footnotetext{
${ }^{138}$ CVM, Processo no 2009/1956, Reg. Col. no 6360/09, Rel. Diretor Eliseu Martins, Voto da Presidente, $\begin{array}{llllll}\text { Rio de } & \text { Janeiro, } & 15 & \text { jul. } & 2009 . & \text { Disponível em }\end{array}$ <http://www.cvm.gov.br/decisoes/2009/20090715_R2.html>. Acesso em 13 mai. 2019.

${ }^{139}$ CVM, Processo no 2009/1956, Reg. Col. no 6360/09, Rel. Diretor Eliseu Martins, Voto do Diretor Otavio Yazbek, Rio de Janeiro, 15 jul. 2009. Disponível em <http://www.cvm.gov.br/decisoes/2009/20090715_R2.html>. Acesso em 13 mai. 2019.

${ }^{140}$ EIZIRIK, Nelson. Lei das S.A comentada: artigos 206 ao 300. $2^{\mathrm{a}}$ ed.. São Paulo: Quartier Latin, 2015. p. 330 .
} 
àquelas relacionadas aos deveres e responsabilidades impostos ao acionista controlador $^{141}$.

Assim como não parece coerente dispensar a obrigação de OPA $a$ posteriori nos casos de não exercício efetivo do poder de comando da companhia (requisito este previsto na alínea b) do artigo 116 da Lei das S.A.), tanto por parte do controlador alienante quanto por parte do adquirente, também não se deve basear no reconhecimento implícito da lei em relação à figura do controle minoritário.

Até mesmo porque nas companhias sob controle minoritário, não existe um "bloco de controle", mas apenas um conjunto de ações com direito a voto que, dependendo, permite ao seu titular exercer as prerrogativas do poder de controle. ${ }^{142}$

Conforme explicado por Luiz Gastão Paes de Barros Leães ${ }^{143}$, não existe, na alienação de controle minoritário, aquela presunção de uso efetivo do poder de controle.

De fato, conforme exposto anteriormente, no caso de alienação do controle majoritário, ainda que o controlador alienante não exercesse o poder de controle, ou o novo controlador, após adquirir as ações do bloco de controle, decida não exercê-lo, ele poderá fazer uso desse poder momento que desejar. Já no caso de alienação de controle minoritário, não há como afirmar, com certeza, que o adquirente poderá exercer o comando da companhia a qualquer momento, quando desejar.

O exercício, ou a possibilidade do exercício do poder de controle pelo adquirente do controle minoritário só será devidamente comprovada depois de observada a sua conduta permanente como titular da maioria deliberante na

\footnotetext{
${ }^{141}$ SIQUEIRA, Carlos Augusto Junqueira de. Transferência do Controle Acionário: Interpretação e Valor. Niterói: FMF, 2004. p. 70.

${ }_{142}$ EIZIRIK, Nelson. Lei das S.A comentada: artigos 206 ao 300. $2^{\mathrm{a}}$ ed.. São Paulo: Quartier Latin, 2015. p. 331.

${ }^{143}$ LEÃES, Luiz Gastão Paes de Barros. Novos Pareceres. São Paulo: Singular, 2018. p. 525.
} 
assembleia e na gestão da companhia. Depende, portanto, da verificação de um fato futuro, não havendo como, na transferência de valores mobiliários em percentual inferior a 50\%, obrigar a que se proceda, em seguida, ao mecanismo da oferta pública. ${ }^{144}$

Imagine o seguinte cenário: um acionista titular de $25 \%$ das ações votantes de uma companhia, que consegue prevalecer nas deliberações sociais e, portanto, orientar os negócios da companhia, em virtude da grande dispersão acionária e ausência de boa parte dos demais acionistas, decide alienar suas ações para um determinado investidor interessado em adquiri-las. Ainda que tenha pago ágio na operação, pela possibilidade de prevalecer nas deliberações sociais com $25 \%$ das ações votantes, é razoável exigir que esse investidor realize uma oferta pública para adquirir as ações de todos os demais acionistas votantes da companhia?

Até mesmo porque, se esses demais acionistas - que, em conjunto, são maioria - não se interessam na gestão da companhia, se ausentando das deliberações sociais, dificilmente serão impactados pela mudança de controlador, dificilmente terão opinião formada sobre determinados assuntos que possam conflitar com as decisões tomadas pelo novo controlador.

E, de qualquer modo, a vontade do titular de $25 \%$ das ações votantes só irá prevalecer em razão da ausência dos titulares dos demais $75 \%$. Se os interesses dos demais acionistas forem realmente afetados pelas novas orientações fixadas pelo controlador, não caberia a eles começar a se interessar e participar das deliberações? Sob o critério democrático da maioria, se o interesse do controlador é contrário ao interesse de todos os demais, estes, organizados em conjunto, verão sua vontade prevalecer.

\footnotetext{
${ }^{144}$ LEÃES, Luiz Gastão Paes de Barros. Novos Pareceres. São Paulo: Singular, 2018. p. 525.
} 


\subsubsection{Prêmio de permanência}

$\mathrm{O} \S 4^{\circ}$ do artigo 254-A da Lei das S.A. confere ao adquirente do controle a possibilidade de oferecer aos acionistas minoritários a opção de permanecer na companhia, pagando a eles um prêmio correspondente à diferença entre o valor de mercado das ações e o valor pago por cada ação pertencente ao bloco de controle: trata-se do prêmio de permanência.

É praticamente pacífico o entendimento, especialmente com a redação do $\S 1^{\circ}$ do artigo 30 da Instrução CVM n $361 / 02^{145}$, no sentido de que o oferecimento dessa alternativa aos minoritários não descarta a obrigatoriedade da OPA prevista no caput do artigo 254-A. Trata-se de uma faculdade conferida ao adquirente do controle, que poderá adota-la cumulativamente com a oferta pública, se assim o desejar. ${ }^{146} \mathrm{O}$ adquirente do controle continua sendo obrigado a proceder à oferta pública, cabendo aos minoritários decidirem qual caminho preferem adotar.

$\mathrm{Na}$ hipótese de o adquirente do controle oferecer essa alternativa, o minoritário que optar por ela abre mão da venda das suas ações na OPA por alienação de controle, permanecendo integrado ao quadro social da companhia. Pode ser vantajoso para ambas as partes na medida em que o adquirente do controle tem um dispêndio menor na operação, por não ter que comprar a ação do minoritário, mas apenas pagar o prêmio de permanência. ${ }^{147}$ Não deixa de ser um ônus ao adquirente e um possível entrave à realização de alienações de

\footnotetext{
${ }_{145}$ Art. 30. Na forma do $\S 4 \mathrm{o}$ do art. 254-A da Lei 6.404/76, o adquirente do controle acionário poderá oferecer aos acionistas minoritários destinatários da OPA um prêmio no mínimo equivalente à diferença entre o valor de mercado das ações e o valor pago por ação integrante do bloco de controle.

$\S 1^{\circ}$ Oferecida tal faculdade, os acionistas poderão manifestar, no leilão da OPA, sua opção por receber o prêmio, ao invés de aceitar a OPA, entendendo-se que todos os acionistas que não se manifestarem aceitam e fazem jus ao prêmio.

${ }^{146}$ EIZIRIK, Nelson. Lei das S.A comentada: artigos 206 ao 300. $2^{\mathrm{a}}$ ed.. São Paulo: Quartier Latin, 2015. p. 335.

${ }^{147}$ PENNA, Paulo Eduardo. Alienação de Controle de Companhia Aberta. São Paulo: Quartier Latin, 2012. p. 249-251.
} 
controle, porém em menores proporções do que a OPA prevista no caput do artigo 254-A.

O minoritário, por sua vez, retém as suas ações, fazendo jus, portanto, ao seu valor de mercado, e recebe em dinheiro, a título de prêmio de permanência, montante equivalente ao prêmio de controle (isto é, o valor adicional pago ao controlador alienante, que corresponde à diferença do valor de mercado das ações e o valor pago pelo conjunto das ações do bloco de controle). ${ }^{148} \mathrm{Nada}$ impede que o minoritário decida, um tempo depois, vender suas ações em bolsa ou mercado de balcão de modo que, ao final, terá embolsado $100 \%$ do valor que o adquirente do controle havia pago por ação integrante do bloco de controle. ${ }^{149}$

Além disso, a opção do prêmio de permanência ajuda a afastar o risco de perda de liquidez das ações da companhia, uma vez que a adesão dos minoritários à oferta pública e a consequente aquisição de suas ações pelo adquirente do controle (que terá concentrado em suas mãos, além das ações do bloco de controle, as ações dos minoritários aderentes da OPA) podem afetar o valor das ações em bolsa. Ainda que prefiram permanecer com a titularidade das ações, minoritários podem se ver compelidos a aderir à OPA, por temerem essa perda de liquidez e os impactos negativos no valor de suas ações. ${ }^{150}$

No entanto, o prêmio de permanência não parece ser uma prática adotada pelos adquirentes do controle de companhias abertas: de acordo com Paulo Penna $^{151}$, uma análise dos 29 editais de OPAs por alienação de controle

148 PENNA, Paulo Eduardo. Alienação de Controle de Companhia Aberta. São Paulo: Quartier Latin, 2012. p. 250.

149 Supondo que o valor de mercado de cada ação da companhia corresponda a R\$ 1,00 e, em uma operação de alienação de controle, o adquirente aceita pagar pelo conjunto das ações do bloco de controle o equivalente a R \$ 1,30 por cada uma dessas ações. Na hipótese do caput do artigo 254-A, o adquirente do controle deve realizar uma OPA aos minoritários pelo preço mínimo de $\mathrm{R} \$ 1,04$ (80\% de $\mathrm{R} \$ 1,30)$ por ação; já na hipótese do $\S 4^{\circ}$, o adquirente não adquire nenhuma ação do minoritário, mas lhe paga R\$ 0,30 por ação, justamente pelo mesmo ter optado em permanecer na companhia ao invés de vender suas ações na OPA. Se minoritário opta pelo prêmio de permanência e, um tempo depois, vende suas ações no mercado secundário, ele terá recebido, ao final, $\mathrm{R} \$ 0,30$ (prêmio de permanência) + R \$1,00 (venda pelo valor de mercado) por ação, ou seja, o montante de $\mathrm{R} \$ 1,30$, equivalente ao preço recebido pelo controlador quando da alienação de controle.

150 PENNA, Paulo Eduardo. Op. cit., p. 250-251.

151 Ibid. p. 251. 
registrados na CVM nos anos de 2007, 2008 e 2009 revela que em nenhuma das ofertas foi oferecido aos minoritários o prêmio permanência.

\subsection{Boa prática de Governança Corporativa}

Com a entrada da Lei $n^{\circ} 10.303 / 01$, que reinseriu a OPA por alienação de controle, e a maior repercussão do movimento de governança corporativa, o tag along veio a ser pauta no mercado de capitais brasileiro, como um dos mecanismos de governança corporativa.

Tanto a cartilha de Recomendações da CVM sobre Governança Corporativa $^{152}$ quanto o Código das Melhores Práticas de Governança Corporativa do IBGC $^{153}$ vieram a aconselhar o direito ao tag along. Tais instrumentos não possuem força legal, sendo meras sugestões de aprimoramento das práticas de governança corporativa. ${ }^{154}$

Além disso, todos os segmentos especiais da bolsa de valores brasileira, atual B3, com exceção do Nível 1, preveem em seus regulamentos, dentre as práticas de governança corporativa adicionais às previstas na legislação societária, a OPA por alienação de controle a todas as ações da companhia não pertencentes ao bloco de controle - ou seja, tanto ordinárias quanto preferenciais, se houver ${ }^{155}$ - por valor unitário correspondente a $100 \%$ do preço pago por ação do bloco de controle (e não 80\%, como previsto no artigo 254-A da Lei das S.A.).

152 CVM. Recomendações da CVM sobre Governança Corporativa. Disponível em <http://www.cvm.gov.br/export/sites/cvm/decisoes/anexos/0001/3935.pdf>. Acesso em 11 mai. 2019.

153 IBGC, Código das Melhores Práticas de Governança Corporativa. Disponível em <https://conhecimento.ibgc.org.br/Lists/Publicacoes/Attachments/21138/Publicacao-IBGCCodigoCodigodasMelhoresPraticasdeGC-5aEdicao.pdf>. Acesso em 11 mai. 2019.

154 PENNA, Paulo Eduardo. Alienação de Controle de Companhia Aberta. São Paulo: Quartier Latin, 2012. p. 265.

155 Conforme visto no item 2.1.2., as empresas que aderirem aos segmentos do Novo Mercado e Bovespa Mais só poderão ter seu capital social formado por ações ordinárias (B3 - Brasil, Bolsa, Balcão. Segmentos de listagem. Disponível em <http://www.b3.com.br/pt_br/produtos-e-servicos/solucoespara-emissores/segmentos-de-listagem/sobre-segmentos-de-listagem/>. Acesso em 11 mai. 2019). 


\subsection{Finalidades do Tag Along obrigatório e sua (in)eficiência}

Existe uma estreita relação entre as normas legais de proteção aos direitos dos acionistas minoritários nas companhias abertas - bem como a seriedade da aplicação de tais normas - e o estágio de desenvolvimento do mercado de capitais. ${ }^{156}$

Por isso, é preciso ter em mente que as regras de limitação do poder decisório do acionista controlador e a tutela dos interesses dos demais acionistas possui uma finalidade maior, qual seja, a proteção e o desenvolvimento do mercado de capitais que, por sua vez, possui papel determinante na economia de um país. O investidor, ao decidir se e onde deve aplicar seus recursos financeiros, leva em conta o nível de confiança e segurança que determinado investimento pode lhe proporcionar.

A finalidade do tag along obrigatório vai além da mera proteção ao minoritário: a lógica é que, com mais e melhores direitos, investidores estarão mais propensos a investir em companhias abertas, o que, por sua vez, estimulará novas companhias a abrirem o seu capital social. ${ }^{157}$ Não à toa, a regra do artigo 254-A da Lei das S.A. não é aplicável às companhias fechadas - onde os minoritários, inclusive, encontram muito mais dificuldade de se desfazer das suas ações, uma vez que estas não são negociadas no mercado de valores mobiliários.

Levando em conta essa finalidade maior, qual seja, o fortalecimento do mercado de capitais, os minoritários podem se deparar com situações que não sejam de seu agrado, mas que também não justifiquem uma norma protetiva nesse sentido, uma vez que a mesma acabaria por prejudicar o desenvolvimento

\footnotetext{
${ }^{156}$ BARBOSA, Marcelo S. A proteção dos direitos dos acionistas minoritários e o mercado de capitais. In: SADDI, Jairo. Fusões e Aquisições: aspectos jurídicos e econômicos. São Paulo: IOB, 2002. p. 410.

${ }^{157}$ PENNA, Paulo Eduardo. Alienação de Controle de Companhia Aberta. São Paulo: Quartier Latin, 2012. p. 71.
} 
do mercado de capitais como um todo. Seria o caso da obrigatoriedade de OPA por alienação de controle?

Além do contexto histórico, narrado no item 3.1.1., que deu origem ao revogado artigo 254 da Lei das S.A., algumas são as causas apontadas por aqueles que defendem até hoje a referida proteção, prescrita no atual artigo 254A da Lei das S.A. e incentivada no mercado de capitais como prática de governança corporativa.

\subsubsection{Tratamento equitativo e prêmio de controle}

A reintrodução do artigo 254-A pela Lei $n^{\circ}$ 10.303/01 reforçou a ideia de um valor econômico próprio do bloco de ações representativas do controle de uma companhia, legitimando a apropriação de parte do prêmio de controle pelo controlador alienante, e instituindo a socialização da outra parte desse prêmio, conferindo ao acionista minoritário o direito de receber $80 \%$ do preço, por ação, pago ao controlador. ${ }^{158}$

O dispositivo em questão também não deixou dúvidas de que a obrigatoriedade de oferta pública nele prevista é destinada apenas aos titulares das ações com direito a voto - ou seja, aquelas que possuem a mesma essência das ações integrantes do bloco de controle e, inclusive, têm o potencial de integrar o bloco de controle. Assim, a norma ali contida não se fundamentaria em um tratamento igualitário, mas em um tratamento equitativo. ${ }^{159}$

Conforme preceitua Roberta Nioac ${ }^{160}$, o legislador quis "agradar gregos e troianos": reintroduziu o direito dos minoritários alienarem suas ações quando da alienação privada do controle da companhia, conferindo-lhes uma segurança

\footnotetext{
${ }^{158}$ PENNA, Paulo Eduardo. Alienação de controle de companhia aberta. In: COELHO, Fábio Ulhoa (Coord.). Tratado de direito comercial: relações societárias e mercado de capitais. São Paulo: Saraiva, 2015. p. 305.

${ }^{159}$ Ibid. p. 306.

${ }^{160}$ PRADO, Roberta Nioac. Oferta Pública de Ações Obrigatória nas S.A.. São Paulo: Quartier Latin, 2005. p. 112.
} 
a mais, o que poderia tornar o mercado de capitais mais atrativo para minoritários investirem; mas ao mesmo tempo, reconheceu a exclusiva propriedade do controlador em (uma pequena) parte do prêmio de controle.

Para mensurar o valor do prêmio de controle de uma companhia, ou seja, da diferença entre o valor que o interessado em adquirir o controle está disposto a pagar pelo conjunto das ações integrantes do bloco controle e o valor de mercado dessas ações se fossem individualmente consideradas, avalia-se o potencial de lucratividade da companhia, também denominado de goodwill. ${ }^{161}$

O potencial de lucratividade se consubstancia na diferença entre o valor dos bens da companhia quando organizados em conjunto e a soma do valor de cada um desses bens separados, o que ajuda a identificar a perspectiva de rentabilidade que aquela companhia pode gerar e, por consequência, servirá como base na definição do preço a ser pago pelo poder de controle. ${ }^{162}$

Tendo em vista que esse potencial de lucratividade pertence à companhia, fazendo parte de seu patrimônio e, portanto, de todos os seus acionistas, há quem entenda, conforme visto no item 1.3.1., que o prêmio de controle também não pertence somente ao acionista controlador, mas a todos os acionistas da companhia (não sendo sequer coerente, portanto, uma norma protetiva apenas àqueles com direito de voto).

Ocorre que o goodwill permanece na empresa, ainda que haja uma mudança de acionista controlador. ${ }^{163}$ Não é como se a empresa fosse perde-lo, como se ele fosse alienado junto com as ações do bloco de controle, não fazendo sentido a obrigação de pagar aos demais acionistas um determinado valor a título de goodwill, pois este continuará integrando o patrimônio da companhia.

Além disso, quanto maior o valor atribuído ao poder de controle de uma companhia, maior é sua perspectiva de rentabilidade e, portanto, maior é o lucro

\footnotetext{
${ }^{161}$ PRADO, Roberta Nioac. Oferta Pública de Ações Obrigatória nas S.A.. São Paulo: Quartier Latin, 2005. p. 338-339.

162 Ibid. p. 339-340.

${ }^{163}$ Ibid. p. 340.
} 
que ela pode gerar. Ou seja, maior deveria ser o interesse do acionista minoritário em permanecer na empresa em vista da perspectiva dos dividendos que teria a receber. E maior seria o valor de mercado das ações da companhia, podendo o acionista que, mesmo assim, queira se retirar, vende-las no mercado. ${ }^{164}$

Uma hipótese que justificaria, nessa linha de pensamento, a extensão do prêmio de controle aos demais acionistas - tanto ordinários quanto preferenciais - seria a de alienação de controle em que os adquirentes intencionem a extinção da companhia (por exemplo, comprar o controle de uma companhia para, em seguida, incorpora-la em outra empresa - hipótese esta que, inclusive, foi uma das causas que originaram a criação do artigo 254 , conforme visto no item 3.1.1.). Neste caso, no preço pago pelo controle estará embutido não apenas o poder de controlar a empresa mas principalmente todo o seu ativo. ${ }^{165}$

De qualquer modo, fato é que o adquirente está interessado no conjunto de ações detidas pelo acionista controlador justamente por representar, na companhia, uma posição diversa daquela conferida pelas ações dos demais acionistas e, por isso, the atribui preço superior àquele que estaria disposto a pagar pelas outras ações votantes não integrantes do bloco de controle.

Conforme preceitua Fábio Ulhoa Coelho, essa sobrevalorização das posições acionarias do titular do poder de controle é "natural, justa e racional", uma vez que o controlador tem o poder de eleger administradores, definir a remuneração deles, fixar a orientação última dos negócios, alterar a estrutura jurídica da sociedade, influir no seu planejamento estratégico, entre outros. ${ }^{166}$

\footnotetext{
${ }^{164}$ PRADO, Roberta Nioac. Oferta Pública de Ações Obrigatória nas S.A.. São Paulo: Quartier Latin, 2005. p. 340-341.

${ }^{165}$ Id., Da obrigatoriedade por parte do adquirente do controle de sociedade por ações de capital aberto de fazer simultânea oferta pública, em iguais condições, aos acionistas minoritários - Art. 254 da Lei 6.404/76 e Resolução CMN 401/76 — É efetivo mecanismo de proteção aos minoritários?. Revista de Direito Mercantil, Industrial, Econômico e Financeiro. São Paulo, n. 106, p. 105, ano XXXVI, abr./jun. 1997.

${ }^{166}$ COELHO, Fábio Ulhoa. Curso de direito comercial: direito de empresa. $15^{\text {a }}$ ed.. São Paulo: Saraiva, 2011. v. 2. p. 312.
} 
Não haveria motivo para impor o mesmo tratamento a acionistas que, por mais que sejam titulares de ações da mesma espécie, possuem funções distintas na companhia.

\subsubsection{Mudança na pessoa do controlador}

Existe o peculiar entendimento, como o de Nelson Eizirik ${ }^{167}$, de que os minoritários, ao decidirem investir em determinada companhia, levam em consideração quem é o seu controlador, e é nele que depositam sua confiança, tratando-se de relação intuitu personae. Por isso, em caso de alienação de controle, lhes é conferido o direito de saída da companhia junto ao até então acionista controlador, caso não concordem em se associar ao novo controlador.

Ocorre que, como se bem sabe, nas companhias e, especialmente, nas companhias abertas, não importa a pessoa do sócio, mas o capital que representa cada ação - não à toa, tem-se nelas a livre cessibilidade das ações. ${ }^{168}$ A relação dos sócios é intuitu pecuniae:

A sociedade anônima é uma sociedade de capital, o que significa que o interesse em sua constituição é intuitu pecuniae, significa que o interesse das pessoas físicas e jurídicas em sua formação é o de reunir capitais, ficando em plano secundário o relacionamento que os interessados possam ter entre si. ${ }^{169}$

Na sociedade anônima, o que ganha relevância é a aglutinação de capitais, não importando a pessoa dos sócios. A cada sócio é indiferente a pessoa dos demais sócios, não havendo entre estes o chamado intuitu personae.

A associação é, na verdade, de capitais, pois estes é que são fundamentais para a existência e continuidade da sociedade. Esses capitais têm, evidentemente, titulares, mas esses titulares poderão variar constantemente, até diariamente, sem que a sociedade seja em nada afetada. ${ }^{170}$

${ }^{167}$ EIZIRIK, Nelson. Lei das S.A comentada: artigos 206 ao 300. $2^{\mathrm{a}}$ ed.. São Paulo: Quartier Latin, 2015. p. 310-313.

168 MARTINS, Fran. Curso de direito comercial: empresa comercial, empresários individuais, microempresas, sociedades comerciais, fundo de comercio. $30^{a}$ ed.. Rio de Janeiro: Forense, 2005. p. 287.

169 ALFREDO NETO, Gonçalves de Assis. Características e natureza da sociedade anônima. In: COELHO, Fábio Ulhoa (Coord.). Tratado de direito comercial: tipos societários, sociedade limitada e sociedade anônima. São Paulo: Saraiva, 2015. p. 329.

${ }^{170}$ BORBA, José Edwaldo Tavares. Direito societário. 13ª ed.. Rio de Janeiro: Renovar, 2012. p. 170. 
A premissa de que o acionista minoritário investe na companhia levando em conta a identidade do acionista controlador, conquanto possa ser verdadeira em alguns casos, mostra-se incompatível com o pressuposto básico, sobre o qual a LSA se assenta, de ser a sociedade anônima, notadamente a companhia aberta, uma sociedade de capitais, e não de pessoas, em que prevalece o caráter intuitu pecuniae. ${ }^{171}$

Além disso, se esse fosse o fundamento do artigo 254-A, o dispositivo não seria muito coerente, uma vez que os destinatários da OPA por alienação de controle são apenas os acionistas (não controladores) com direito de voto. Porém eventuais efeitos da troca de controle são sentidos por todos os acionistas da companhia - votantes e não votantes. ${ }^{172}$

Some isso ao fato de que essa imposição não abarca todas as situações de mudança do controle (interno) de uma companhia: a companhia pode vir a ter um novo controlador sem que isso implique na realização de uma oferta pública para os demais acionistas. É o caso da escalada em bolsa e da OPA para aquisição de controle (trata-se de OPA a priori e voluntária, mecanismo de aquisição de controle disciplinado no artigo 257 da Lei das S.A., que não se confunde a OPA a posteriori, condição de eficácia da cessão privada de controle imposta pelo artigo 254-A).

Em breve síntese, na escalada em bolsa, o interessado na aquisição do controle adquire sucessivamente em bolsa de valores ações da companhia, com o auxílio ou não de aquisições privadas realizadas com acionistas minoritários, até atingir percentual do capital social com direito a voto da companhia que lhe assegure o poder de controle. Já na OPA de aquisição do controle, o interessado propõe, utilizando-se de qualquer meio de publicidade ou esforço de aquisição, aos acionistas de uma companhia ou de determinada classe ou espécie de ações

\footnotetext{
${ }^{171}$ PENNA, Paulo Eduardo. Alienação de Controle de Companhia Aberta. São Paulo: Quartier Latin, 2012. p. 148.

${ }^{172}$ Id., Alienação de controle de companhia aberta. In: COELHO, Fábio Ulhoa (Coord.). Tratado de direito comercial: relações societárias e mercado de capitais. São Paulo: Saraiva, 2015. p. 306.
} 
da companhia, a aquisição das respectivas ações em montante tal qual the assegure o poder de controle da companhia. ${ }^{173}$

Essas duas modalidades de aquisição (originária) de controle só são possíveis em companhias com maior dispersão acionária, em que não há um acionista titular de mais da metade das ações com direito de voto. Ou a companhia não tinha um controlador definido, passando a ter, ou havia um controlador minoritário, que passa a não mais deter o poder de controle, alterando-se a pessoa do controlador. Com isso, a companhia tende a possuir uma maior concentração acionária - fato este tão criticado pelos defensores do tag along obrigatório e que fundamentaria essa proteção.

\subsubsection{Private benefits of control}

Algumas teorias e estudos apontam também para a possibilidade dos controladores expropriarem (tanto de forma lícita quanto ilícita) da companhia certos benefícios, especialmente pecuniários, em detrimento dos demais acionistas; de usufruir de bens da companhia, em situações de interesse personalíssimo e sem qualquer relação com o interesse da companhia, e, muitas vezes, sem que os acionistas minoritários sequer conheçam esta realidade. ${ }^{174}$

Nesses casos, o prêmio de controle que o adquirente do controle se dispõe a pagar é ainda mais alto, pois engloba não só o preço relativo à condução da atividade empresarial, como outras vantagens a serem aproveitadas exclusivamente pelo acionista controlador - são os denominados private benefits of control. Por isso, o prêmio deveria ser compartilhado com os acionistas

\footnotetext{
${ }^{173}$ OIOLI, Erik Frederico. Oferta Pública de Aquisição de Controle de Companhias Abertas. São Paulo: Quartier Latin, 2010. p. 81-82.

${ }^{174}$ PRADO, Roberta Nioac. Oferta Pública de Ações Obrigatória nas S.A.. São Paulo: Quartier Latin, 2005. p. 346-349.
} 
minoritários, evitando que o controlador se aproprie de todo o sobrepreço pago pelas ações do bloco de controle. ${ }^{175}$

Em outras palavras, o interessado em comprar as ações do acionista controlador é obrigado, pela Lei das S.A., a realizar uma oferta pública para aquisição das demais ações (com direito de voto) da companhia, pois presumese que ele pretende, ao adquirir o controle, obter para si determinadas vantagens (que supostamente seriam, em grande parte dos casos, ilícitas) no comando da companhia.

A solução correta, contudo, não parece ser a obrigatoriedade de OPA por alienação de controle, mas munir o Estado de mecanismos legais e regulamentares eficientes para fiscalizar e combater os desvios e excessos de poder de comando dos controladores e, após o devido processo legal, se for o caso, punir, exemplarmente, administrativa, civil e penalmente os controladores que tenham indevidamente expropriado bens e direitos da companhia, ou obtido, para si ou para outrem, vantagens financeiras. ${ }^{176}$

\subsubsection{Concentração acionária}

A obrigatoriedade de OPA por alienação de controle parece produzir efeitos opostos aos pretendidos ${ }^{177}$, tanto em relação à mera proteção do acionista minoritário quanto em relação ao desenvolvimento do mercado de capitais.

A oferta pública impõe a quem queira adquirir o controle acionário uma obrigação adicional de grande proporção. Além do desembolso dos valores necessários à aquisição das ações do bloco de controle, deve desembolsar

${ }^{175}$ EIZIRIK, Nelson. Lei das S.A comentada: artigos 206 ao 300. $2^{\mathrm{a}}$ ed.. São Paulo: Quartier Latin, 2015. p. 310-311.

${ }^{176}$ LOBO, Jorge. Tag Along: Uma Análise à Luz da Escola do Realismo Científico. Revista da Emerj. Rio de Janeiro, v. 14, n. 55, p. 259, jul./set. 2011. Disponível em <http://www.emerj.tjrj.jus.br/revistaemerj_online/edicoes/revista55/Revista55_240.pdf >. Acesso em 11 mai. 2019.

177 PERIN JUNIOR, Ecio. A Lei n. 10.303/2001 e a proteção do acionista minoritário. São Paulo: Saraiva, 2004. p. 111. 
também a importância relativa à aquisição das demais ações com direito de voto. Por isso, muitos interessados em adquirir o controle de determinada companhia poderão se ver desencorajados a realizar esse tipo de operação.

Se a companhia está sofrendo dificuldades financeiras, necessitando de aporte de capital e uma nova orientação nos negócios sociais, a aquisição do controle por um novo empreendedor e a mudança na figura do controlador tem grandes chances de beneficiar a companhia e, por conseguinte, seus acionistas. Mas esse novo empreendedor se verá desencorajado a adquirir o controle se, para tanto, for necessária a realização de oferta pública para aquisição das ações de todos os demais acionistas com direito de voto. Desistindo da operação, a companhia seguirá no comando do mesmo acionista controlador que a inseriu nesse cenário de complicações. Nesse sentido:

É evidente que a necessidade de injeção de capital na empresa adquirida conflita frontalmente com a obrigação de fazer oferta pública aos acionistas minoritários, da qual resultará dispêndio de recursos não revertidos em favor da capitalização da empresa adquirida. Dessa maneira, a obrigatoriedade da oferta pública produz o pior dos mundos. Ao mesmo tempo, inibe e dificulta processos de alienação de controle necessários ao saneamento de empresas - daí a importância de revogá-la do ponto de vista da privatização - e produz situação desfavorável aos minoritários, uma vez que o não saneamento de uma empresa resulta em queda do valor de suas ações, no que se prejudicam, mais que todos, os acionistas minoritários. ${ }^{178}$

Ademais, a realização da OPA por alienação de controle e a aceitação (seja maciça ou não) da oferta por acionistas minoritários mantêm (senão aumentam) o controle concentrado da companhia e têm como consequência a perda de liquidez das ações da companhia. Afinal, o adquirente do controle terá concentrado em suas mãos, além das ações do bloco de controle, as ações dos minoritários que aderiram à OPA.

Receosos dessa possível perda de liquidez das ações na hipótese de aceitação da oferta pública por alguns minoritários, outros se verão tentados a

${ }_{178}$ PERIN JUNIOR, Ecio. A Lei n. 10.303/2001 e a proteção do acionista minoritário. São Paulo: Saraiva, 2004. p. 111. 
aceitá-la também, ainda que, a princípio, desejassem permanecer na companhia - provocando uma perda de liquidez ainda maior que, por sua vez, resultará em um menor interesse de ingresso na companhia por novos investidores do mercado.

Visando evitar tal cenário, os Regulamentos do Novo Mercado e do Nível 2 conferem uma proteção adicional nesse sentido: após uma operação de alienação de controle, o adquirente, quando necessário, deverá tomar as medidas cabíveis, de modo a recompor o free float mínimo das ações, correspondente a $25 \%$ por cento do total do capital social da companhia, dentro dos 6 meses subsequentes à alienação de controle. ${ }^{179} \mathrm{Ou}$ seja, acrescenta mais um ônus ao adquirente do controle, desencorajando ainda mais a troca de controle da companhia, que acabará permanecendo com o mesmo controlador - seja ele eficiente ou não no comando da companhia.

A verdade é que a concentração acionária acaba sendo incentivada com a tutela da rápida saída do acionista minoritário da companhia caso sejam tomadas certas decisões contrárias ao seu interesse. São clássicos exemplos o direito de retirada, previsto em diversas hipóteses (tais como nos artigos 136-A, 137, 221 e 252 da Lei das S.A.), e as OPAs (por cancelamento de registro, aumento de participação do controlador ou alienação de controle). ${ }^{180}$

Ou seja, a liquidez das ações é viabilizada por esses mecanismos, quando, na verdade, deveria ser buscada no mercado secundário (Bolsa de Valores e Mercado de Balcão). E acaba se privilegiando muito mais o investidor de curto prazo do que o de longo prazo, o que é contraproducente para o adequado desenvolvimento do mercado de capitais. ${ }^{181}$

\footnotetext{
${ }^{179}$ PENNA, Paulo Eduardo. Alienação de Controle de Companhia Aberta. São Paulo: Quartier Latin, 2012. p. 270.

${ }^{180}$ OIOLI, Erik Frederico. Oferta Pública de Aquisição de Controle de Companhias Abertas. São Paulo: Quartier Latin, 2010. p. 55.

${ }^{181}$ PRADO, Roberta Nioac. Oferta Pública de Ações Obrigatória nas S.A.. São Paulo: Quartier Latin, 2005. p. 344.
} 
As normas societárias deveriam visar ao correto desenvolvimento do mercado de capitais brasileiro, sanando as macrodeficiências do sistema ${ }^{182}$, com a imposição de regras de full disclosure, de deveres fiduciários para com a companhia e efetiva responsabilização do acionista controlador que cometer ilícitos.

182 PRADO, Roberta Nioac. Oferta Pública de Ações Obrigatória nas S.A.. São Paulo: Quartier Latin, 2005. p. 346. 


\section{Conclusão}

A Lei das S.A. reconhece a figura do acionista controlador de uma companhia como aquele que, fazendo uso das ações com direito de voto que detém na companhia, consegue prevalecer nas deliberações sociais, elegendo administradores, conduzindo os negócios e fixando o planejamento estratégico da empresa. Em razão dessa preponderância na gestão da companhia, possui também deveres, obrigações e responsabilidades próprias a ele. Distingue-se, portanto, dos demais acionistas com direito de voto da companhia, os denominados acionistas minoritários.

Embora esse poder de controlar a companhia seja, em muitas ocasiões, prerrogativa de acionistas titulares de mais da metade das ações votantes, é plenamente possível que o controle seja exercido pelo titular de um percentual menor de ações, em companhias cujas demais ações se encontrem muito dispersas, os demais acionistas não consigam se organizar ou se ausentem das deliberações sociais. Na verdade, o acionista minoritário desinteressado na gestão da companhia é um fenômeno frequente em inúmeras e nas mais diversas companhias.

Por conferirem ao seu titular não apenas os direitos inerentes a qualquer outro acionista, mas também a possibilidade de comandar a companhia, o conjunto das ações que formam o bloco de controle possui valor de mercado maior do que aquele atribuído às mesmas ações individualmente consideradas. Por isso, é natural que um eventual interessado no controle de uma companhia aberta se disponha a pagar esse valor adicional (também chamado de prêmio de controle) pelas ações do bloco de controle. Por outro lado, não se justificaria o pagamento desse mesmo valor para a aquisição das demais ações não pertencentes ao bloco de controle.

O compartilhamento do prêmio de controle pode, inclusive, desincentivar o controlador a gerir da melhor forma possível os negócios sociais, o que 
impacta diretamente na perspectiva de rentabilidade da empresa e, por consequência no valor das ações no mercado e, mais ainda, no valor do prêmio de controle - que se afigura proporcional à sua atuação e aos seus direitos e deveres na companhia.

Também não se justifica a obrigação de, sempre que o acionista controlador alienar suas ações, o adquirente destas realizar oferta pública de aquisição de todas as demais ações com direito de voto. Trata-se de ônus excessivo conferido ao potencial adquirente do controle, que, por sua vez, pode acabar desistindo de realizar o negócio, tendo em vista que terá que arcar com os custos relativos não só à compra das ações do bloco de controle, mas à compra de todas as ações com direito de voto da companhia. Inviabiliza a troca de controle que pode, muitas vezes, ser benéfica à companhia (especialmente se estiver passando por dificuldades financeiras, com uma gestão ineficiente comandada pelo acionista controlador) e aos seus acionistas minoritários.

Sem contar que a alteração no quadro acionário de uma companhia, ainda mais de capital aberto, é normal e inerente à sua natureza. Não se pode justificar o direito de saída conjunta de todos os acionistas com direito de voto sempre que houver mudança na figura do acionista controlador.

A presunção de vantagens ilícitas obtidas pelo acionista controlador também não pode, de jeito algum, fundamentar o tag along obrigatório. Significaria admitir a inobservância das normas societárias de transparência e informação, bem como as falhas de fiscalização e responsabilização existentes no mercado de capitais brasileiro, sem tentar, contudo, corrigir e aperfeiçoar esses mecanismos.

Por fim, a realização de OPA por alienação de controle propicia maior concentração acionária e perda de liquidez das ações, uma vez que o adquirente do controle terá em suas mãos, além das ações do bloco de controle, as ações de todos os minoritários que decidirem vender suas ações: seja porque preferem sair da companhia - o que poderiam fazer vendendo suas ações (que, na maior 
parte dos casos, possuem liquidez) no mercado secundário, seja porque assistiram alguns outros minoritários aderirem à OPA, ficando receosos da possível perda de liquidez gerada por essa adesão, gerando um verdadeiro efeito dominó. 


\section{Bibliografia}

ALFREDO NETO, Gonçalves de Assis. Características e natureza da sociedade anônima. In: COELHO, Fábio Ulhoa (Coord.). Tratado de direito comercial: tipos societários, sociedade limitada e sociedade anônima. São Paulo: Saraiva, 2015. p. 321-344.

AMENDOLARA, Leslie. Direito dos Acionistas Minoritários. $3^{\text {a }}$ ed.. São Paulo: Quartier Latin, 2012. 308 p.

BARBOSA, Marcelo S. A proteção dos direitos dos acionistas minoritários e o mercado de capitais. In: SADDI, Jairo. Fusões e Aquisições: aspectos jurídicos e econômicos. São Paulo: IOB, 2002. p. 408-435.

BERLE, Adolf A.; MEANS, Gardiner C. A moderna sociedade anônima e a propriedade privada. Tradução de Dinah de Abreu Azevedo. São Paulo: Abril Cultural, 1984. 335 p.

BORBA, José Edwaldo Tavares. Direito societário. $13^{\mathrm{a}}$ ed.. Rio de Janeiro: Renovar, 2012. 595 p.

BRASIL. Lei $n^{\circ}$ 6.385, de 7 de dezembro de 1976. Dispõe sobre o mercado de valores mobiliários e cria a Comissão de Valores Mobiliários. Disponível em <http://www.planalto.gov.br/ccivil_03/leis/16385.htm>. Acesso em 17 mai. 2019.

BRASIL. Lei $n^{\circ}$ 6.404, de 15 de dezembro de 1976. Dispõe sobre as Sociedades por Ações. Disponível em 
<http://www.planalto.gov.br/ccivil_03/leis/16404consol.htm>. Acesso em 17 mai. 2019.

BRASIL. Lei $n^{\circ}$ 9.457, de 5 de maio de 1997. Altera dispositivos da Lei n ${ }^{\circ} 6.404$, de 15 de dezembro de 1976, que dispõe sobre as sociedades por ações e da Lei $\mathrm{n}^{\circ}$ 6.385, de 7 de dezembro de 1976, que dispõe sobre o mercado de valores mobiliários e cria a Comissão de Valores Mobiliários. Disponível em <http://www.planalto.gov.br/ccivil_03/leis/L9457.htm>. Acesso em 17 mai. 2019.

BRASIL. Lei $n^{o}$ 10.303, de 31 de outubro de 2001. Altera e acrescenta dispositivos na Lei no 6.404, de 15 de dezembro de 1976, que dispõe sobre as Sociedades por Ações, e na Lei no 6.385, de 7 de dezembro de 1976, que dispõe sobre o mercado de valores mobiliários e cria a Comissão de Valores Mobiliários. Disponível em <http://www.planalto.gov.br/ccivil_03/leis/leis_2001/110303.htm>. Acesso em 17 mai. 2019.

B3 - Brasil, Bolsa, Balcão. Segmentos de listagem. Disponível em <http://www.b3.com.br/pt_br/produtos-e-servicos/solucoes-paraemissores/segmentos-de-listagem/sobre-segmentos-de-listagem/>. Acesso em 11 mai. 2019.

CAMPINHO, Sérgio. Curso de direito comercial: sociedade anônima. $2^{\mathrm{a}}$ ed.. São Paulo: Saraiva, 2017. 456 p.

CANTIDIANO, Luiz Leonardo. Alienação e aquisição de controle. Revista de Direito Mercantil, Industrial, Econômico e Financeiro. São Paulo, n. 59, p. 5667, ano XXIV, jul./set. 1985. 
CANTIDIANO, Luiz Leonardo. Características das ações, cancelamento de registro e "tag along". In: LOBO, Jorge (Coord.). Reforma da Lei das Sociedades Anônimas. Rio de Janeiro: Forense, 2002. p. 61-105.

CARVAlHOSA, Modesto. Comentários à Lei de Sociedades Anônimas: arts.

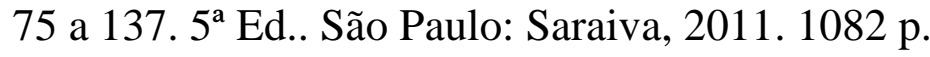

CARVAlHOSA, Modesto. Comentários à lei de sociedades anônimas: arts. 243 a 300. $5^{\text {a }}$ ed.. São Paulo: Saraiva, 2011. 608 p.

CARVALHOSA, Modesto; KUYVEN, Luiz Fernando Martins. Sociedades anônimas. In: CARVALHOSA, Modesto (Coord.). Tratado de Direito Empresarial. São Paulo: Revista dos Tribunais, 2016. v. 3. 1245 p.

COELHO, Fábio Ulhoa. Curso de direito comercial: direito de empresa. $15^{\mathrm{a}}$ ed.. São Paulo: Saraiva, 2011. v. 2. 548 p.

COMPARATO, Fábio; SALOMÃO FILHO, Calixto. O Poder de Controle na Sociedade Anônima. $5^{\mathrm{a}}$ ed.. Rio de Janeiro: Forense, 2008. 597 p.

CONSELHO MONETÁRIO NACIONAL, Resolução $n^{o} 401$, de 22 de dezembro de $2016 \quad$ (revogada). Disponível em <https://www.bcb.gov.br/estabilidadefinanceira/exibenormativo?tipo=Resolu \%C3\%A7\%C3\%A3o\&numero=401>. Acesso em 17 mai. 2019.

CVM, Instrução $n^{\circ}$ 323, de 19 de janeiro de 2000. Define hipóteses de exercício abusivo do poder de controle e de infração grave. Disponível em 
<http://www.cvm.gov.br/legislacao/instrucoes/inst323.html>. Acesso em 16 mai. 2019.

CVM, Instrução $n^{\circ} 324$, de 19 de janeiro de 2000. Fixa escala reduzindo, em função do capital social, as porcentagens mínimas de participação acionária necessárias ao pedido de instalação de Conselho Fiscal de companhia aberta previsto no $\S 20$ do art. 161 da Lei no 6.404, de 15 de dezembro de 1976. Disponível em <http://www.cvm.gov.br/legislacao/instrucoes/inst324.html>. Acesso em 17 mai. 2019.

CVM, Instrução $n^{o} 361$, de 5 de março de 2002. Dispõe sobre o procedimento aplicável às ofertas públicas de aquisição de ações de companhia aberta, o registro das ofertas públicas de aquisição de ações para cancelamento de registro de companhia aberta, por aumento de participação de acionista controlador, por alienação de controle de companhia aberta, para aquisição de controle de companhia aberta quando envolver permuta por valores mobiliários, e de permuta por valores mobiliários, revoga a Instrução CVM n 229, de 16 de janeiro de 1995, a Instrução CVM nº 299, de 9 de fevereiro de 1999 e a Instrução CVM n $^{\circ} 345$, de 4 de setembro de 2000, e dá outras providências. Disponível em <http://www.cvm.gov.br/legislacao/instrucoes/inst361.html>. Acesso em 17 mai. 2019.

CVM. O mercado de valores mobiliários brasileiro. $3^{\text {a }}$ ed. Rio de Janeiro: Comissão de Valores Mobiliários, 2014. Disponível em $<$ http://www.investidor.gov.br/portaldoinvestidor/export/sites/portaldoinvestid or/publicacao/Livro/LivroTOP-CVM.pdf>. Acesso em 12 mai. 2019.

CVM, Processo nº 2001/10329, Reg. n 3528/02, Rel. Diretor Marcelo Trindade, Rio de Janeiro, 19 fev. 2002. Disponível em 
<http://www.cvm.gov.br/decisoes/2002/20020219_R1.html>. Acesso em 13 mai. 2019.

CVM, Processo no 2005/4069, Reg. no 4788/05, Rel. Pedro Oliva Marcilio de Sousa, Rio de Janeiro, 11 abr. 2006. Disponível em <http://www.cvm.gov.br/decisoes/2006/20060411_R1.html>. Acesso em 14 mai. 2019.

CVM, Processo $n^{\circ}$ 2006/6209, Reg. $n^{\circ}$ 5256/2006, Rel. Diretor Wladimir Castelo Branco Castro, Rio de Janeiro, 25 set. 2006. Disponível em <http://www.cvm.gov.br/decisoes/2006/20060925_R1.html>. Acesso em 17 mai. 2019.

CVM, Processo $n^{\circ}$ 2006/7658, Reg. $n^{\circ}$ 5464/07, Rel. SRE/GER-1, Rio de $\begin{array}{lllll}\text { Janeiro, } & 11 & \text { abr. } & 2007 . & \text { Disponível }\end{array}$ <http://www.cvm.gov.br/decisoes/2007/20070411_R1.html>. Acesso em 14 mai. 2019.

CVM, Processo no 2007/7230, Reg. nº 5533/07, Rel. Eli Loria, 11 jul. 2007. Disponível em <http://www.cvm.gov.br/decisoes/2007/20070711_R2.html>. Acesso em 15 mai. 2019.

CVM, Processo $n^{\circ}$ 2007/14099, Reg. Col. no 5801/2008, Rel. Diretor Durval Soledade, Rio de Janeiro, 29 jan. 2008. Disponível em <http://www.cvm.gov.br/decisoes/2008/20080129_R1.html>. Acesso em 13 mai. 2019.

CVM, Processo nº 2009/0471, Reg. nº 6357/09, Rel. Diretor Otavio Yazbek, Rio de Janeiro, 3 mar. 2009. Disponível em 
<http://www.cvm.gov.br/decisoes/2009/20090303_R1/20090303_D07.html>. Acesso em 14 mai. 2019.

CVM, Processo n 2009/1956, Reg. Col. nº 6360/09, Rel. Diretor Eliseu Martins, Rio de Janeiro, 15 jul. 2009. Disponível em <http://www.cvm.gov.br/decisoes/2009/20090715_R2.html>. Acesso em 13 mai. 2019.

CVM, Processo n ${ }^{\circ}$ 2015/8340, Reg. no 9867/15, Rel. SRE/GRE-1, Rio de Janeiro, $29 \quad$ set. $2015 . \quad$ Disponível em <http://www.cvm.gov.br/decisoes/2015/20150929_R1.html>. Acesso em 14 mai. 2019.

CVM. Recomendações da CVM sobre Governança Corporativa. Disponível em <http://www.cvm.gov.br/export/sites/cvm/decisoes/anexos/0001/3935.pdf>. Acesso em 11 mai. 2019.

EIZIRIK, Nelson. Direito Societário: Estudos e Pareceres. São Paulo: Quartier Latin, 2015. 774 p.

EIZIRIK, Nelson. Lei das S.A comentada: artigos 80 ao $137.2^{\text {a }}$ ed.. São Paulo: Quartier Latin, 2015.566 p.

EIZIRIK, Nelson. Lei das S.A comentada: artigos 206 ao 300. $2^{\text {a }}$ ed.. São Paulo: Quartier Latin, 2015. 556 p.

EIZIRIK, Nelson. Temas de direito societário. Rio de Janeiro: Renovar, 2005. 610 p. 
HISTÓRIA do Mercado de Capitais. Portal do Investidor. Disponível em <http://www.investidor.gov.br/menu/Menu_Academico/O_Mercado_de_valor es_mobiliarios_brasileiro/Historia_Mercado-Capitais.html>. Acesso em 12 mai. 2019.

IBGC, Código das Melhores Práticas de Governança Corporativa. Disponível em

<https://conhecimento.ibgc.org.br/Lists/Publicacoes/Attachments/21138/Public acao-IBGCCodigo-CodigodasMelhoresPraticasdeGC-5aEdicao.pdf $>$. Acesso em 11 mai. 2019.

LAMY FILHO, Alfredo; PEDREIRA, José Luiz Bulhões. A lei das S.A.: pressupostos, elaboração, aplicação. Rio de Janeiro: Renovar, 1997. v.1. 508 p.

LAMY FILHO, Alfredo; PEDREIRA, José Bulhões (Coord.). Direito das Companhias. Rio de Janeiro: Forense, 2009. 2189 p.

LEÃES, Luiz Gastão Paes de Barros. Novos Pareceres. São Paulo: Singular, 2018. 1704 p.

LOBO, Jorge. Direito dos Acionistas. Rio de Janeiro: Elsevier, 2011. 406 p.

LOBO, Jorge. Tag Along: Uma Análise à Luz da Escola do Realismo Científico. Revista da Emerj. Rio de Janeiro, v. 14, n. 55, p. 240.260. jul./set. 2011. Disponível em <http://www.emerj.tjrj.jus.br/revistaemerj_online/edicoes/revista55/Revista55_ 240.pdf>. Acesso em 11 mai. 2019. 
MARTINS, Fran. Curso de direito comercial: empresa comercial, empresários individuais, microempresas, sociedades comerciais, fundo de comercio. $30^{\mathrm{a}}$ ed.. Rio de Janeiro: Forense, 2005. 494 p.

MOTTA, Nelson Candido. Alienação de controle de instituições financeiras. Acionistas Minoritários. Notas para uma interpretação sistemática da Lei das S.A. Revista de Direito Mercantil, Industrial, Econômico e Financeiro. São Paulo, n. 46, p. 33-50, ano XXIV, jul./set. 1985.

MUNHOZ, Eduardo Secchi. Aquisição de controle na sociedade anônima. São Paulo: Saraiva, 2013. 413 p.

OIOLI, Erik Frederico. Oferta Pública de Aquisição de Controle de Companhias Abertas. São Paulo: Quartier Latin, 2010. 246 p.

PARENTE, Norma. Mercado de Capitais. In: CARVALHOSA, Modesto (Coord.). Tratado de Direito Empresarial. São Paulo: Revista dos Tribunais, 2016. v. 6. 749 p.

PARENTE, Norma. Principais inovações introduzidas pela Lei n. 10.303, de 31 de outubro de 2001, à Lei das Sociedades por Ações. In: LOBO, Jorge (Coord.). Reforma da Lei das Sociedades Anônimas. São Paulo: Forense, 2002. p. 11-49.

PENNA, Paulo Eduardo. Alienação de Controle de Companhia Aberta. São Paulo: Quartier Latin, 2012. 320 p.

PENNA, Paulo Eduardo. Alienação de controle de companhia aberta. In: COELHO, Fábio Ulhoa (Coord.). Tratado de direito comercial: relações societárias e mercado de capitais. São Paulo: Saraiva, 2015. p. 298-332. 
PERIN JUNIOR, Ecio. A Lei n. 10.303/2001 e a proteção do acionista minoritário. São Paulo: Saraiva, 2004. 158 p.

PRADO, Roberta Nioac. Da obrigatoriedade por parte do adquirente do controle de sociedade por ações de capital aberto de fazer simultânea oferta pública, em iguais condições, aos acionistas minoritários - Art. 254 da Lei 6.404/76 e Resolução CMN 401/76 — É efetivo mecanismo de proteção aos minoritários?. Revista de Direito Mercantil, Industrial, Econômico e Financeiro. São Paulo, n. 106, p. 83-106, ano XXXVI, abr./jun. 1997.

PRADO, Roberta Nioac. Oferta Pública de Ações Obrigatória nas S.A.. São Paulo: Quartier Latin, 2005. 366 p.

SALOMÃO FILHO, Calixto. $O$ novo direito societário. $3^{\text {a }}$ ed.. São Paulo: Malheiros Editores, 2006. 227 p.

SIQUEIRA, Carlos Augusto Junqueira de. Transferência do Controle Acionário: Interpretação e Valor. Niterói: FMF, 2004. 520 p.

UNIÃO EUROPEIA. Directiva 2004/25/CE, relativa às ofertas públicas de aquisição, 21 abr. 2004. Disponível em <https://eur-lex.europa.eu/legalcontent/PT/TXT/?uri=celex:32004L0025>. Acesso 12 mai 2019.

WALD, Arnoldo. Do descabimento da oferta pública de compra em relação às ações preferenciais. Revista de Direito Mercantil, Industrial, Econômico e Financeiro. São Paulo, n. 45, p. 7-19, ano XXI, jan./mar. 1982. 